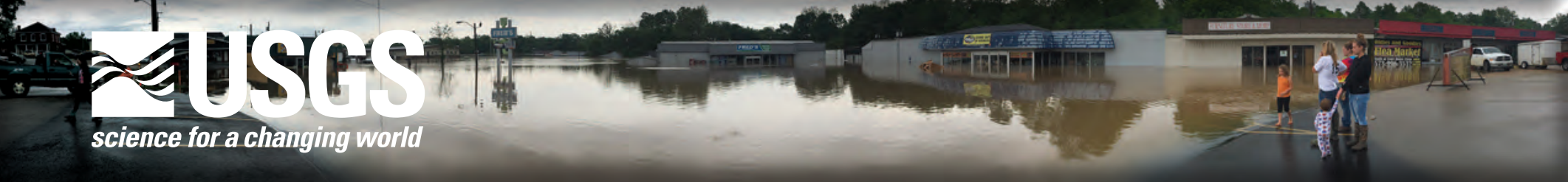

\title{
Flooding in the Southern Midwestern United States, April-May 2017
}
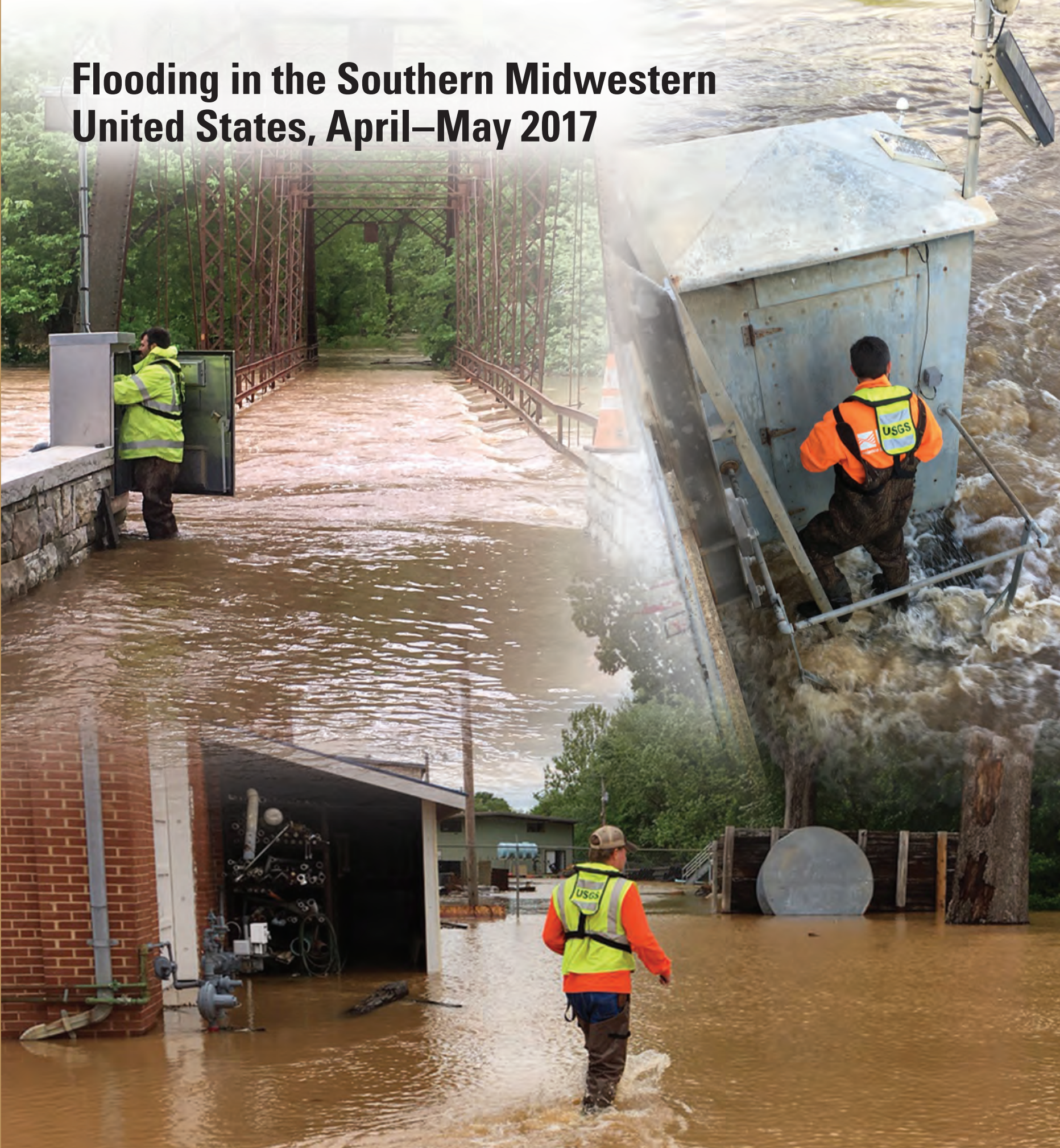

Open-File Report 2018-1004

U.S. Department of the Interior

U.S. Geological Survey 


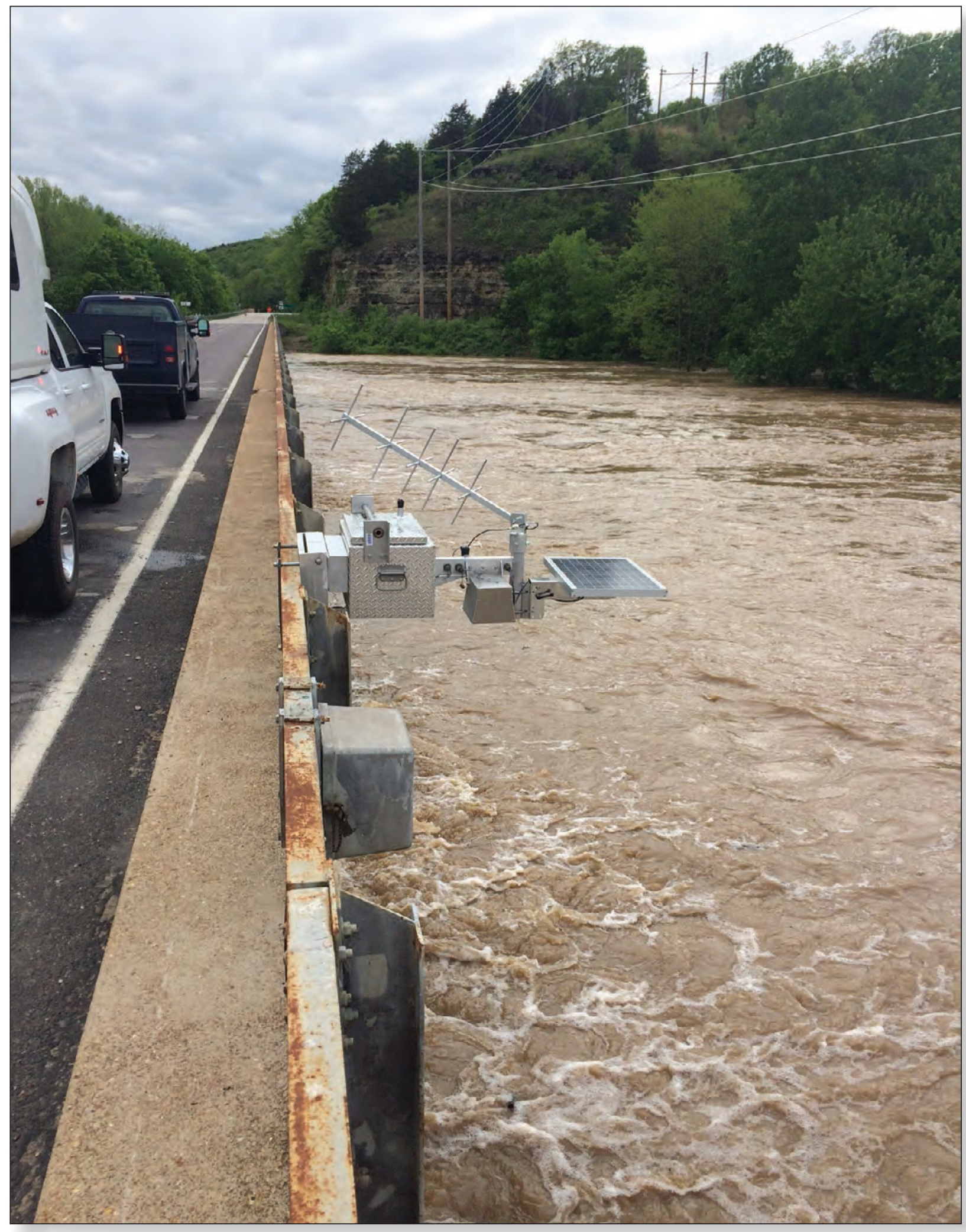

Above: Rapid-deployment gage installation, Gasconade River near Rich Fountain, Mo., May 1, 2017. Photograph by Larry Buschmann, U.S. Geological Survey (USGS).

Front cover. Top center: Floodwater at Current River at Doniphan, Mo., May 1, 2017. Photograph by Shannon Kelly, USGS. Upper left: USGS hydrologic technician inspects gage at Big River at Byrnesville, Mo., May 1, 2017. Photograph by Aaron Walsh, USGS. Upper right: USGS hydrologic technician inspects gage platform at St. Francis River near Patterson, Mo., peak flood, April 30, 2017. Photograph by Josh Keele, USGS. Bottom center: USGS hydrologic technician wading from gage at Black River near Poplar Bluff, Mo., May 1, 2017. Photograph by Jarret Ellis, USGS. 


\section{Flooding in the Southern Midwestern United States, April-May 2017}

By David C. Heimann, Robert R. Holmes, Jr., and Thomas E. Harris

Open-File Report 2018-1004 


\title{
U.S. Department of the Interior \\ RYAN K. ZINKE, Secretary
}

\section{U.S. Geological Survey \\ William H. Werkheiser, Deputy Director exercising the authority of the Director}

\author{
U.S. Geological Survey, Reston, Virginia: 2018
}

For more information on the USGS - the Federal source for science about the Earth, its natural and living resources, natural hazards, and the environment—visit https://www.usgs.gov or call 1-888-ASK-USGS.

For an overview of USGS information products, including maps, imagery, and publications,

visit https://store.usgs.gov.

Any use of trade, firm, or product names is for descriptive purposes only and does not imply endorsement by the U.S. Government.

Although this information product, for the most part, is in the public domain, it also may contain copyrighted materials as noted in the text. Permission to reproduce copyrighted items must be secured from the copyright owner.

Suggested citation:

Heimann, D.C., Holmes, R.R., Jr., and Harris, T.E., 2018, Flooding in the southern Midwestern United States, April-May 2017: U.S. Geological Survey Open-File Report 2018-1004, 36 p., https://doi.org/10.3133/ofr20181004.

ISSN 2331-1258 (online) 


\section{Contents}

Abstract

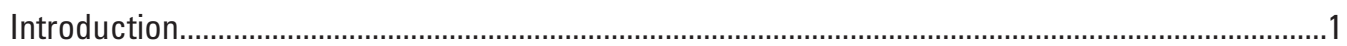

April-May 2017 Flooding —Antecedent Conditions, Chronology, and Magnitude ............................1

Antecedent Streamflow and Weather Conditions for the 2017 Southern

Midwest Flooding ..........................................................................................................

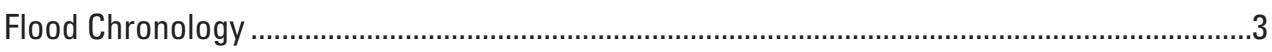

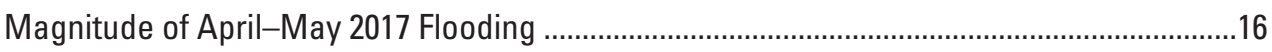

April-May 2017 Flooding —Comparison with Historic Floods ......................................................17

April-May 2017 Flooding —Annual Exceedance Probability..........................................................17

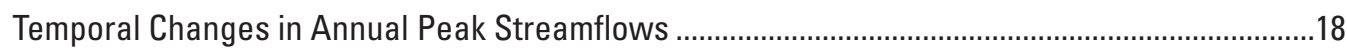

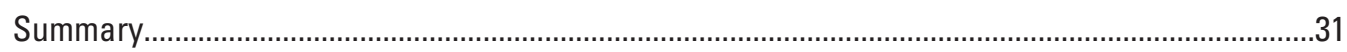

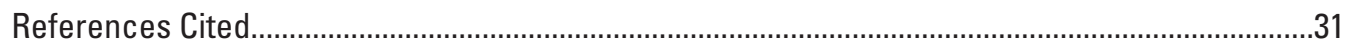

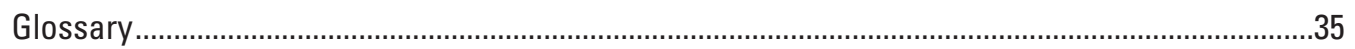

\section{Figures}

1. Map showing the Midwestern United States and flood study area associated with the April-May 2017 flood

2. Map showing location of selected U.S. Geological Survey streamgages and aerial video documentation locations within the designated flood study area ................8

3. Maps showing streamflow conditions at selected U.S. Geological Survey streamgages in the study area before the April-May 2017 flooding including January, February, March, and April of 2017

4. Maps showing monthly precipitation conditions in the United States for January-April 2017, as a percent of normal

5. Map showing the 500 millibar height contours for April 29, 2017, across the continental United States.

6. Maps showing daily surface weather maps at 7:00 AM Eastern Standard Time from April 29 to 30, 2017.

7. Map showing cumulative rainfall totals over the southern Midwest United States during April 28-30, 2017

8. Streamflow hydrographs and precipitation totals and distributions for selected U.S. Geological Survey streamgages and precipitation stations within the study area

9. Graph showing annual number of peak-of-record streamflows and number of U.S. Geological Survey streamgages in the study area with peak streamflow record

10. Map showing the spatial distribution of the magnitude of annual exceedance probabilities of peak streamflows at 59 U.S. Geological Survey streamgages for the April-May 2017 flood.

11. Maps showing percentage changes in median annual peak streamflow values for selected U.S. Geological Survey streamgages for 1930-2017, 1956-2017, 1975-2017, and 1989-2017

12. Maps showing the percentage change in the median annual precipitation by climate division within the study area for 1930-2016, 1956-2016, 1975-2016, and 1989-2016 
13. Graphs showing change in frequency of daily high intensity (greater than 2-3 in.) precipitation from the long-term (1900-2014) average, by state

\section{Tables}

1. Peak streamflow and stage data at selected U.S. Geological Survey streamgages in the flood study area for the flood of April-May 2017

2. Date, times, and locations of aerial video footage documenting the effects of the April-May 2017 flood at selected locations in south-central Missouri.

3. Estimated annual exceedance probability of the 2017 flood peaks and weighted peak streamflow estimates for selected flood quantiles at 59 U.S. Geological Survey streamgages included in this study

\section{Films}

1. Daily distribution of streamflow conditions in the study area,

April 27-May 10, 2017.

2. Spring Creek at Highway AP bridge near Willow Springs, Missouri, April 30, 2017, at 10:30 a.m.

3. North Fork River and Spring Creek at Highway 14, Douglas County,

Missouri, April 30, 2017, at 12:09 p.m.

4. North Fork River at Highway CC, Ozark County, Missouri, April 30, 2017, at 12:37 p.m

5. Bryant Creek at Highway 181, Ozark County, Missouri, April 30, 2017, at 13:06

6. North Fork River at Highway PP near Tecumseh, Missouri, Ozark County, April 30, 2017, at 13:40

7. Dry Creek at Highway AP near Willow Springs, Missouri, April 30, 2017, at $15: 29$ 


\section{Conversion Factors}

U.S. customary units to International System of Units

\begin{tabular}{|c|c|c|}
\hline Multiply & By & To obtain \\
\hline \multicolumn{3}{|c|}{ Length } \\
\hline foot $(\mathrm{ft})$ & 0.3048 & meter $(\mathrm{m})$ \\
\hline mile (mi) & 1.609 & kilometer (km) \\
\hline \multicolumn{3}{|c|}{ Area } \\
\hline square mile $\left(\mathrm{mi}^{2}\right)$ & 259.0 & hectare (ha) \\
\hline square mile $\left(\mathrm{mi}^{2}\right)$ & 2.590 & square kilometer $\left(\mathrm{km}^{2}\right)$ \\
\hline \multicolumn{3}{|c|}{ Flow rate } \\
\hline cubic foot per second $\left(\mathrm{ft}^{3} / \mathrm{s}\right)$ & 0.02832 & cubic meter per second $\left(\mathrm{m}^{3} / \mathrm{s}\right)$ \\
\hline \multicolumn{3}{|c|}{ Pressure } \\
\hline millibar (mbar) & 0.1 & kilopascal (kPa) \\
\hline
\end{tabular}

\section{Datum}

Horizontal coordinate information is referenced to the North American Datum of 1983 (NAD 83).

\section{Abbreviations}

AEP annual exceedance probability

EMA expected moments algorithm

FEMA Federal Emergency Management Agency

ID identifier

RRE regional regression equations

USGS U.S. Geological Survey 
$x=$

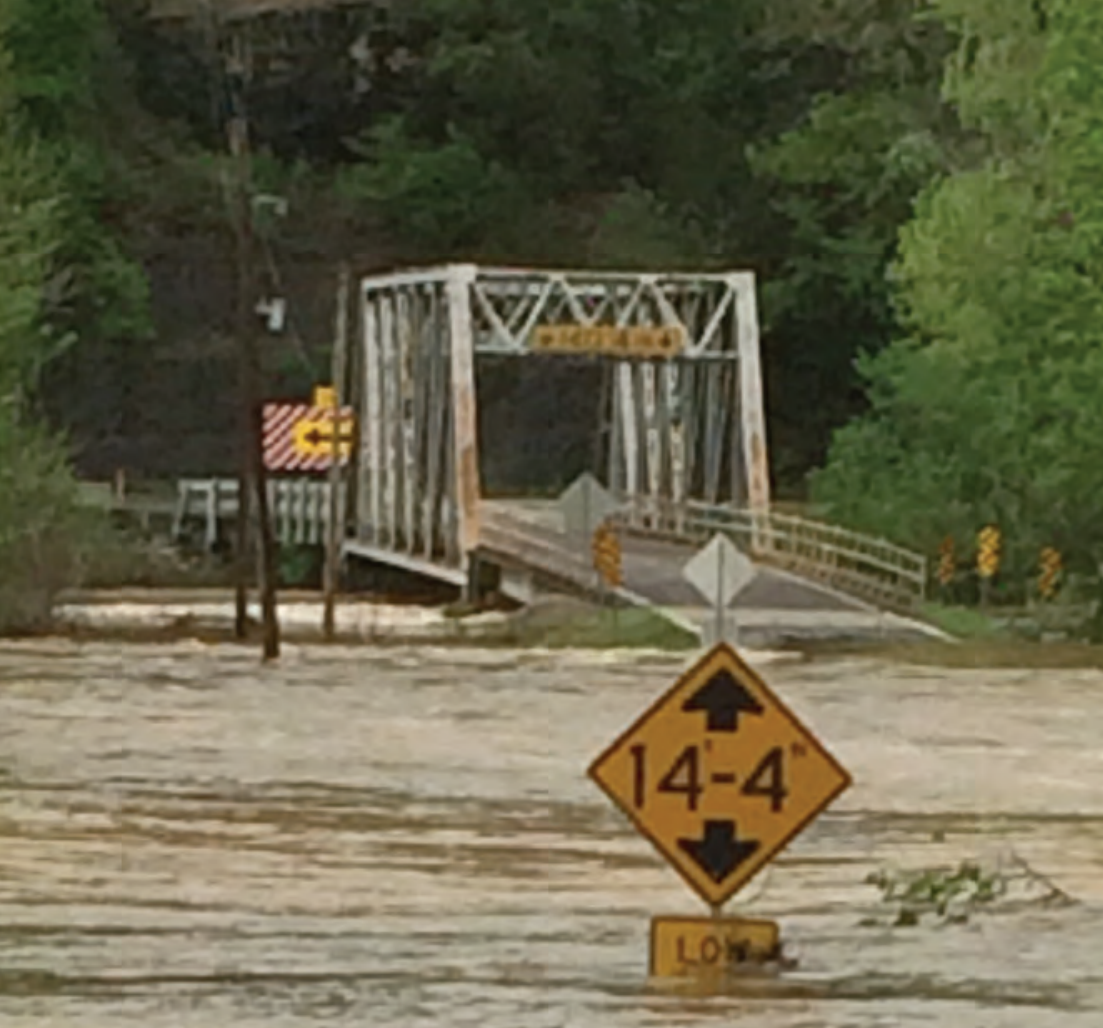




\title{
Flooding in the Southern Midwestern United States, April-May 2017
}

\author{
By David C. Heimann, Robert R. Holmes, Jr., and Thomas E. Harris
}

\section{Abstract}

Excessive rainfall resulted in flooding on numerous rivers throughout the southern Midwestern United States (southern Midwest) in late April and early May of 2017. The heaviest rainfall, between April 28 and 30, resulted in extensive flooding from eastern Oklahoma to southern Indiana including parts of Missouri, Arkansas, and Illinois.

Peak-of-record streamflows were set at 21 U.S. Geological Survey (USGS) streamgages in the southern Midwest during the resulting April-May 2017 flooding and each of the five States included in the study area had at least one streamgage with a peak of record during the flood. The annual exceedance probability (AEP) estimates for the AprilMay 2017 peak streamflows indicate that peaks at 5 USGS streamgages had AEPs of 0.2 percent or less (500-year recurrence interval or greater), and peak streamflows at 15 USGS streamgages had AEPs in the range from greater than 0.2 to 1 percent (500- to 100 -year recurrence intervals).

Examination of the magnitude of the temporal changes in median annual peak streamflows indicated positive increases, in general, throughout the study area for each of the 1930-2017, 1956-2017, 1975-2017, and 1989-2017 analysis periods. The median increase in peak streamflows was greatest in 1975-2017 and 1989-2017 with maximum increases of 8 to 10 percent per year. No stations in the 1975-2017 or 1989-2017 analysis period had median negative changes in peak streamflows.

\section{Introduction}

Excessive rainfall resulted in flooding on numerous rivers throughout the southern Midwestern United States (hereafter referred to as the southern Midwest) in late April and early May of 2017 (fig. 1). Tropical moisture lifted over a stalled frontal system and caused heavy rains from Texas to Ohio between April 28 and May 10 resulting in extensive flooding from eastern Oklahoma to southern Indiana including parts of Missouri, Arkansas, and Illinois. The flooding resulted in 12 deaths, 7 in Arkansas and 5 in Missouri (Cable News Network, 2017). A total of 84 counties (53 in Missouri
[Missouri Department of Public Safety, State Emergency Management Agency, 2017], 18 in Oklahoma [Federal Emergency Management Agency (FEMA), 2017b], and 13 in Arkansas [FEMA, 2017a]) were declared Federal disaster areas. In Missouri alone, the flooding resulted in destruction or damage to more than 1,200 homes and caused at least \$58 million in damage to roads, bridges, and other public infrastructure (Office of Missouri Governor, 2017).

The purpose of this report is to document the flood peaks (stage and streamflow) of selected U.S. Geological Survey (USGS) streamgages within the southern Midwest that were affected by the April-May 2017 floods, placing them in hydrologic context at these selected locations in relation to timing, rank, flood frequency, temporal trends, and historical flooding. The flood peak data are reported for 59 USGS selected streamgages in the southern Midwest including parts of Arkansas, Illinois, Indiana, Missouri, and Oklahoma having more than 25 years of peak streamflow record and, generally having 2017 peak streamflows that were ranked in the top 3 of the annual peaks of record. Flood frequency characteristics for selected stations are provided through the determination of the annual exceedance probabilities (AEPs) of the 2017 flood peaks for the selected stations. The AEP is the probability, or chance, of a flood of a given streamflow magnitude being equaled or exceeded in any given year. Documenting the flood peaks and AEPs will help put the 2017 floods in historical context aiding public and private entities in flood preparedness, protection, and control. The determination of trends in annual streamflow peaks will provide insight into potential changes in the nature of flooding with time and help further inform agencies involved with flood mitigation efforts.

\section{April-May 2017 Flooding-Antecedent Conditions, Chronology, and Magnitude}

The 2017 flooding in the southern Midwest was widespread in that it included parts of Arkansas, Illinois, Indiana, Missouri, and Oklahoma (fig. 1). The April-May 2017 flooding primarily occurred in small basins of less than about 1,000 square miles $\left(\mathrm{mi}^{2}\right)$ but included stations with drainage areas as large as $23,400 \mathrm{mi}^{2}$ (table 1). Streamflow peaks 


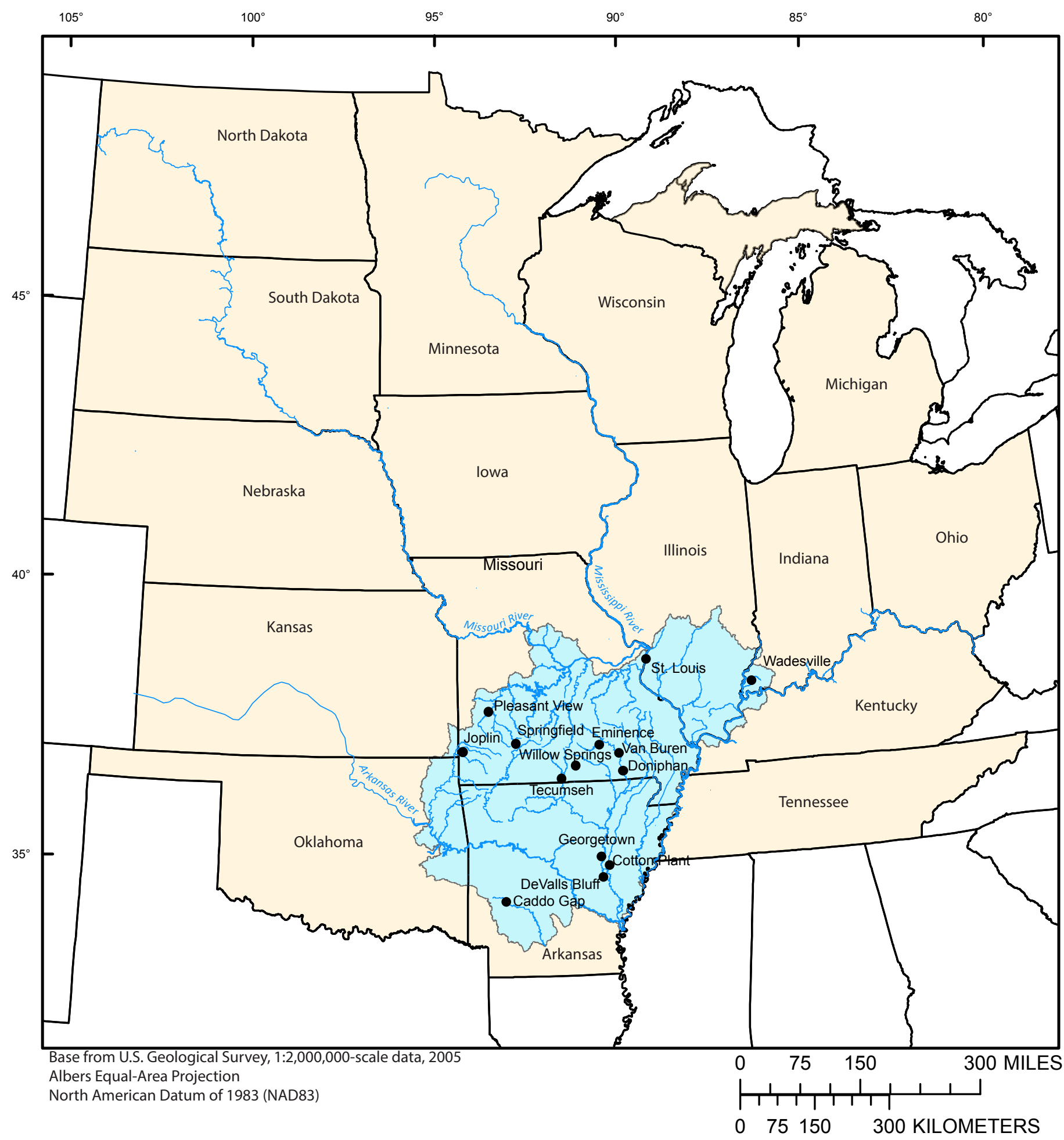

\section{EXPLANATION}

Flood study area

Midwestern United States

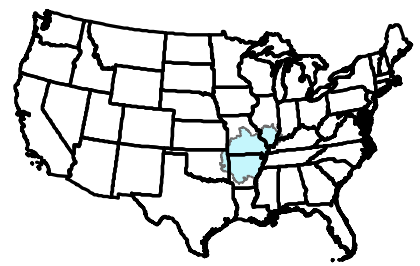

Figure 1. The Midwestern United States and flood study area associated with the April-May 2017 flood. 
on the "big" river (Missouri, Mississippi, Ohio) stations in the study area during the April-May flooding generally were not ranked in the top 5 at any station. Streamflow peaks of record occurred at 21 of the 59 streamgaging stations during the April-May 2017 flooding included in this report (fig. 2, table 1), which is noteworthy given the multi-State spatial distribution of the record peaks and that the average record length of the 59 streamgages was 67 years.

\section{Antecedent Streamflow and Weather Conditions for the 2017 Southern Midwest Flooding}

Much of the area in the southern Midwest that was affected by flooding in April-May 2017 began the year with streamflows in the normal ( 25 to 75 percentile) to below normal (less than 25 percentile) ranges (USGS, 2017b; fig. $3 A$ ), and only the streamflows in the Illinois section of the study area primarily were above normal (greater than 75 percentile). By February, most of the study area had below normal streamflows except some higher than normal streamflows in southwestern Arkansas (fig. 3B). All stations indicated below normal to normal conditions in March with near record lows occurring at several stations in southeast Oklahoma and southwest Arkansas (fig. 3C). These predominantly normal to below normal streamflow conditions persisted through midApril (fig. $3 D$ ) before the start of heavy rains in the study area on April 28.

Because streamflow is primarily reflective of precipitation conditions, it follows that precipitation for January and February 2017 also was average to below normal for much of the study area [National Oceanic and Atmospheric Administration (NOAA), National Centers for Environmental Information, 2017b; fig. 4]. March totals were normal for much of the area with above normal total precipitation in parts of southern Missouri and northern Arkansas. Early to mid-April precipitation also was slightly below normal for Springfield, Mo., and other than a substantial precipitation event during April 4-5, 2017, recorded at Saint Louis, Mo., the remainder of April was fairly dry over the study area until the last week of the month.

\section{Flood Chronology}

A rainfall pattern that led to excessive precipitation falling over much of the southern Midwest began as a surface low pressure center in the four corners region of the western United States on April 27, 2017, that slowly moved southeast over the next 24 hours. On Friday afternoon, April 28, a stationary front that extended from southeast Missouri across west-central Arkansas into south-central Oklahoma began moving north as a warm front. As an upper level system moved out of the southern Rockies, tropical moisture from the Gulf of Mexico began to get pulled northward up and over the stationary front. At the upper levels of the atmosphere, the 500 millibar low pressure was centered over Arizona and had become cutoff from the main flow as it drifted slowly eastward (fig. 5; National Centers for Environmental Prediction, 2017). The result was a convergence of the two fronts producing thunderstorms that trained over the same areas yielding abundant precipitation for the next 24 to 36 hours (fig. 6).

A series of surface lows that moved northeast along the front brought waves of showers and thunderstorms and resulted in continuous heavy rainfall across the study area during the day on Saturday, April 29. Interestingly, this upper level atmospheric pattern was very similar to the upper level pattern that developed during the last historic flooding of December 2015 through January 2016 (Holmes and others, 2016), which also affected much of the same study area. As the warm front continued to move north on Sunday, April 30, the cold front swept in behind it from the west bringing an end to the rainfall (National Weather Service, 2017b). The heaviest rainfall amounts during April 28-30 occurred over extreme northeast Oklahoma and northern Arkansas, across the southern half of Missouri, southern Illinois, and southern Indiana, and included totals of 6 to 10 inches (in.) with some isolated higher amounts (figs. 7, 8). Largely as a result of the April 28-30 rainfall totals, April 2017 was the second wettest April on record in Missouri (123 years of record), the third wettest in Oklahoma, the eighth wettest in Arkansas, and the fifth wettest in Illinois (National Centers for Environmental Information, 2017b). The runoff response from the intense precipitation, as indicated by the streamflow hydrographs, varied in magnitude and temporal distribution (fig. 8). Flood peaks during the event occurred between April 29 and May 10,2017 , with the timing of the peaks primarily determined by the temporal distribution of precipitation and the size of the drainage area upstream from the streamgage. Stations with peaks occurring on April 29 had drainage areas less than $825 \mathrm{mi}^{2}$, whereas those stations with the later peaks (White River at Georgetown, Arkansas, May 8, 2017; White River at DeValls Bluff, Arkansas, May 10, 2017) were large basins (greater than 22,000 $\mathrm{mi}^{2}$ ). Peak streamflows at streamgages along the White River also were affected by regulation, which could contribute to the later peaks. The effects of man-made regulation and the large drainage area are reflected in the hydrograph for the White River at Georgetown, Ark. (station number (no.) 07076750), because the peak was 8 days later than most streamgages in the study area (fig. 8, table 1). The streamflow peak at the Cache River near Cotton Plant, Ark. (station no. 07077555), similarly was lagged compared to other streamgages (fig. 8, table 1). The flood peaks at this streamgage were lagged and extended by a combination of the low gradient (less than 1 foot per mile [ft/mi]) and extensive storage capacity in the wide flood plain containing numerous wetlands. The April 27 to May 10 chronology and spatial progression in streamflow conditions relative to the long-term distribution of daily streamflows indicates the effects of the heavy precipitation throughout the study area (film 1).

Film 1. Daily distribution of streamflow conditions in the study area, April 27-May 10, 2017. Source: U.S. Geological Survey, 2017b. 


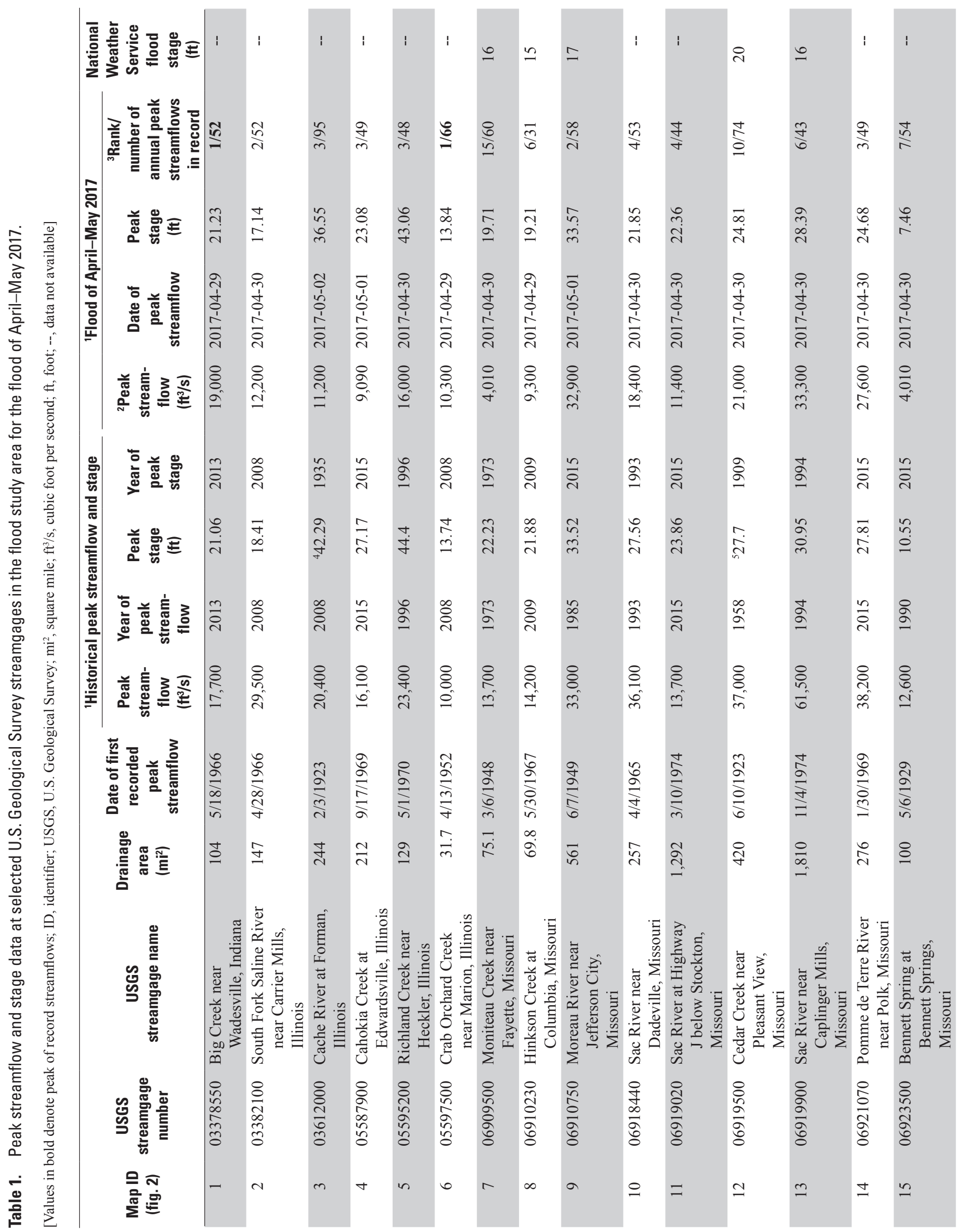




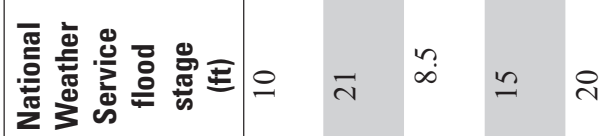

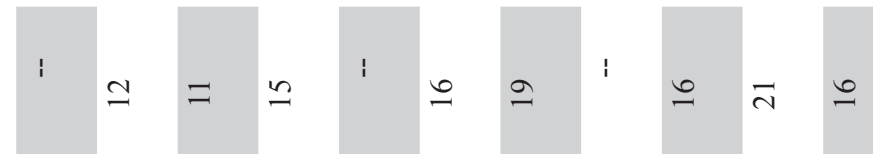

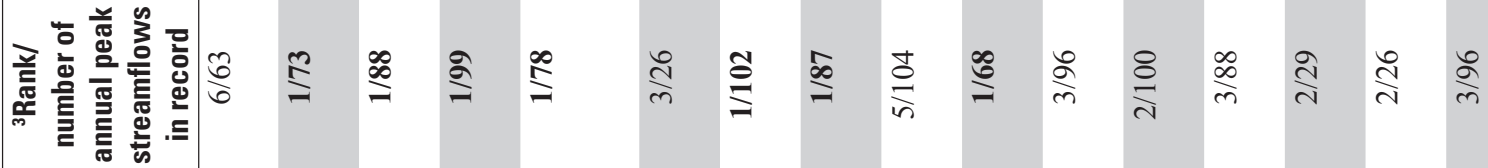
กิ

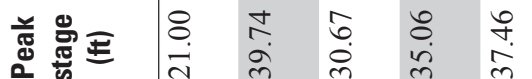
ค.

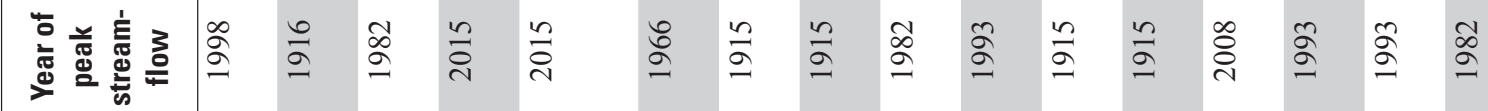

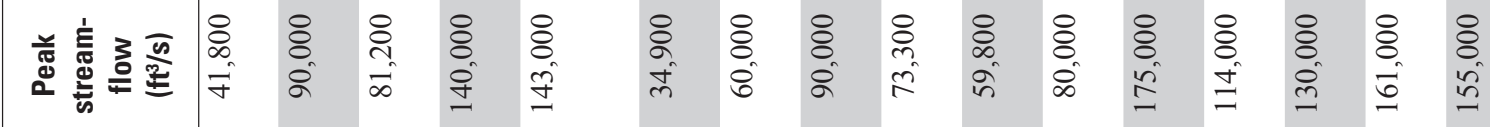

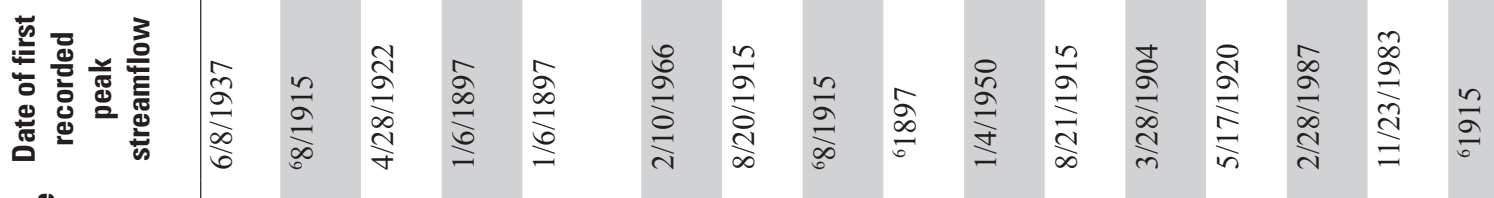

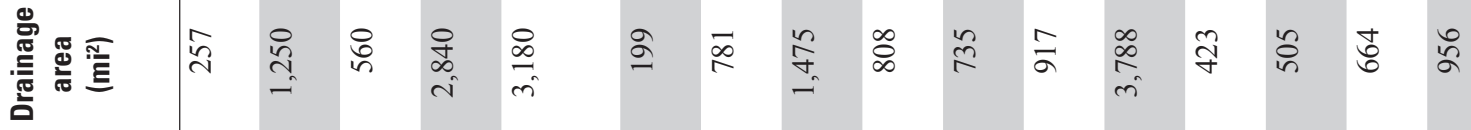

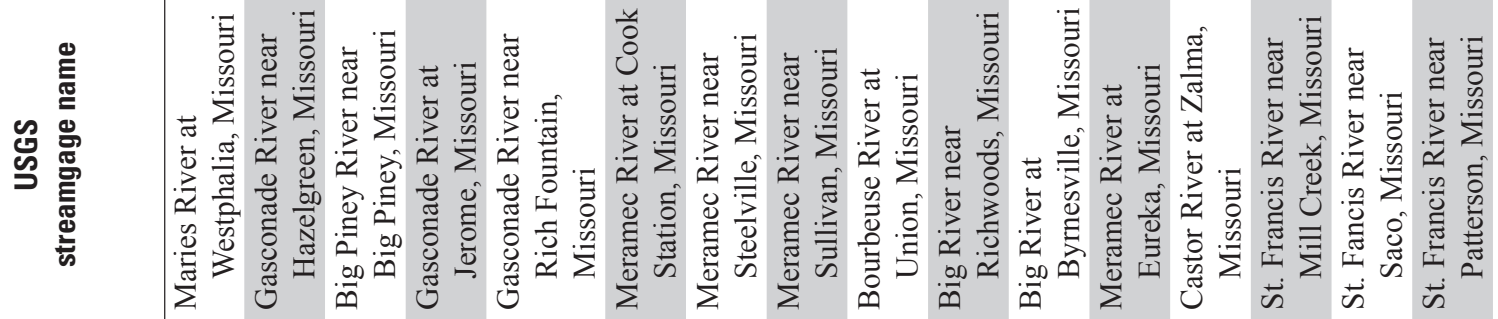

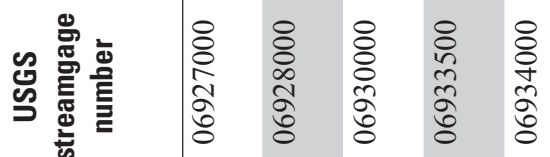

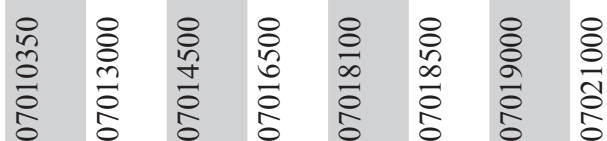

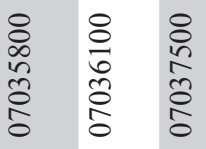

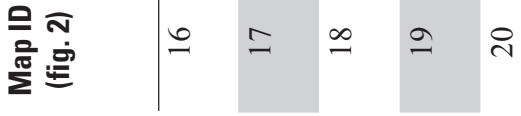

$\overline{\text { ส }}$ กิ 


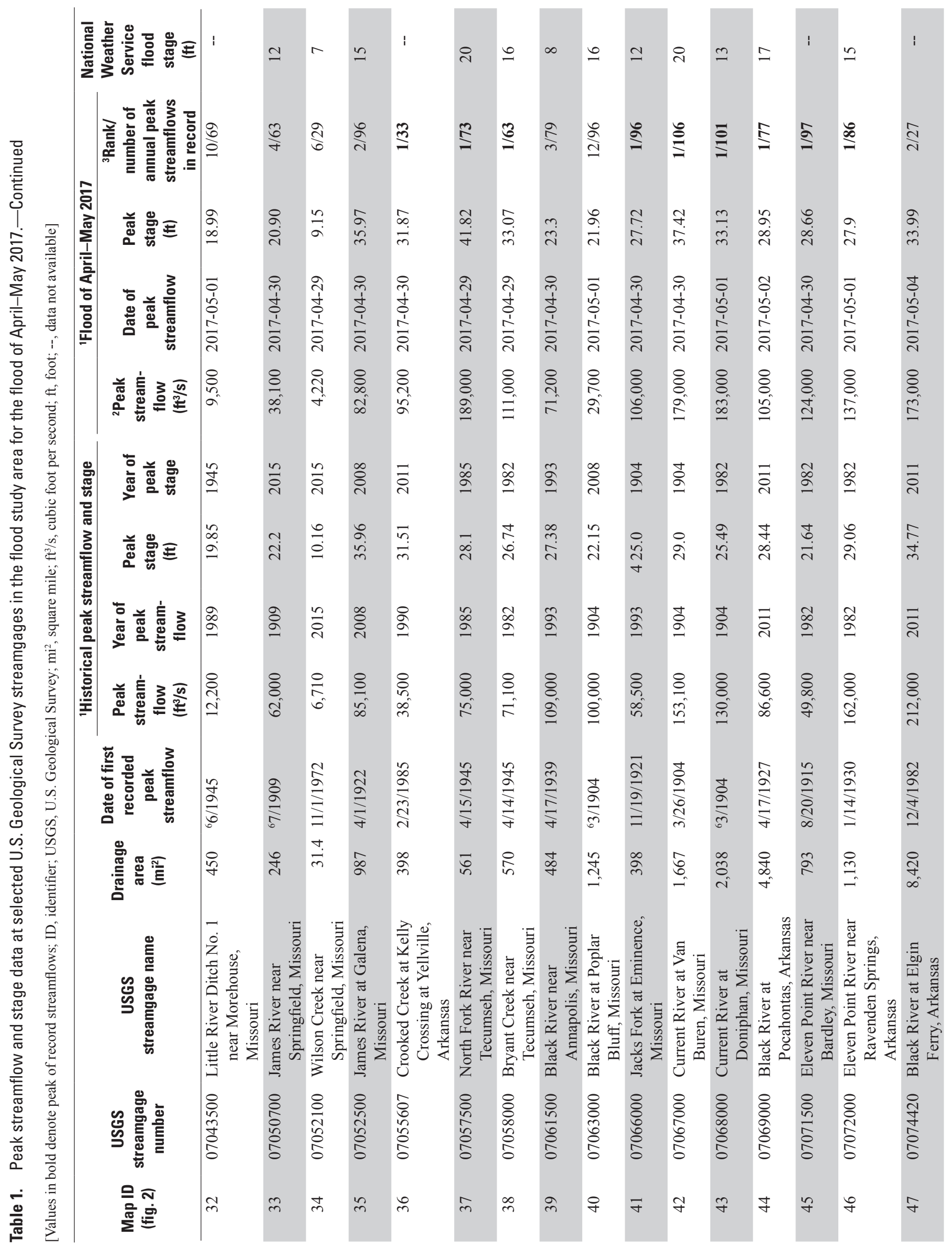




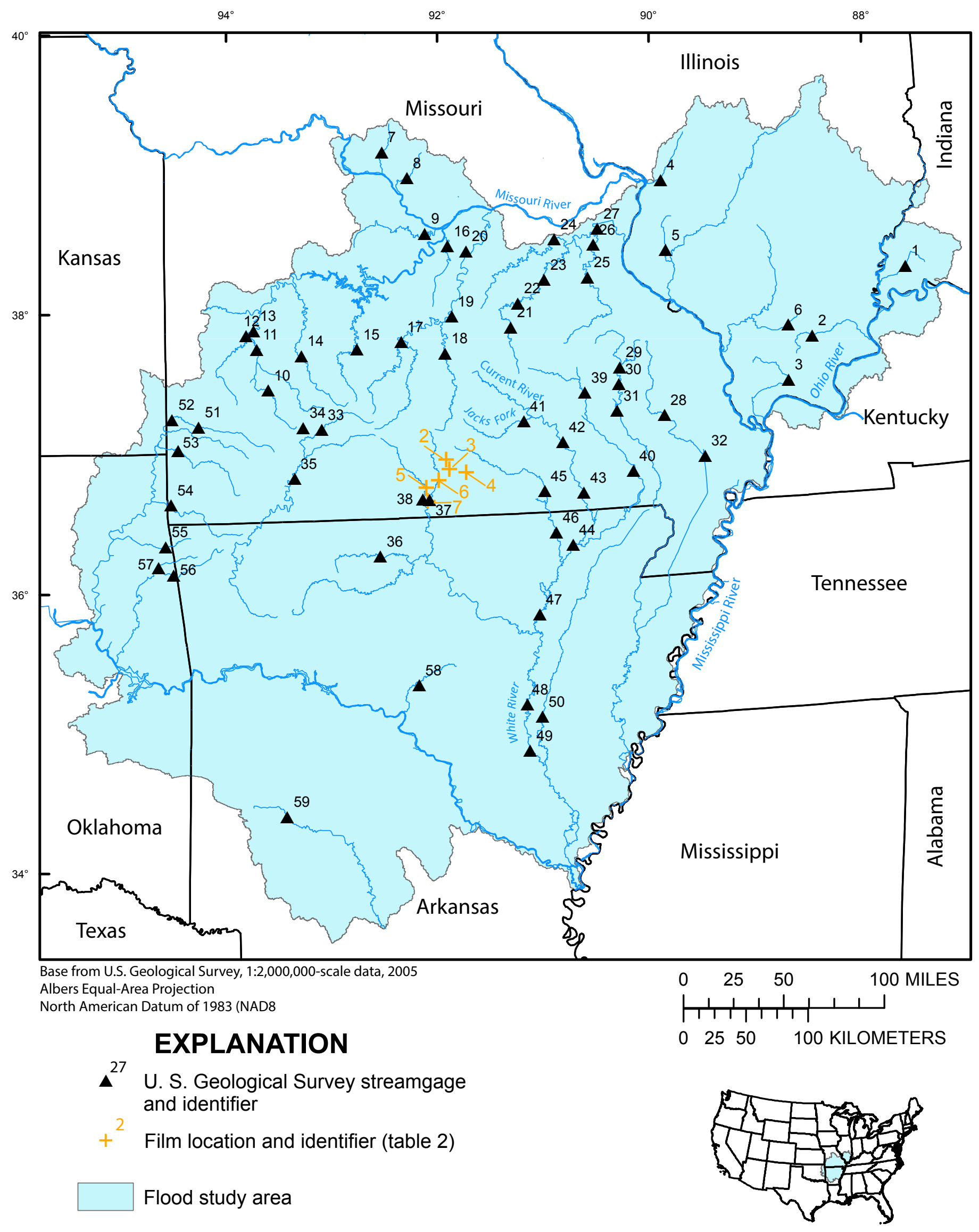

Figure 2. Location of selected U.S. Geological Survey streamgages and aerial video documentation locations within the designated flood study area. 

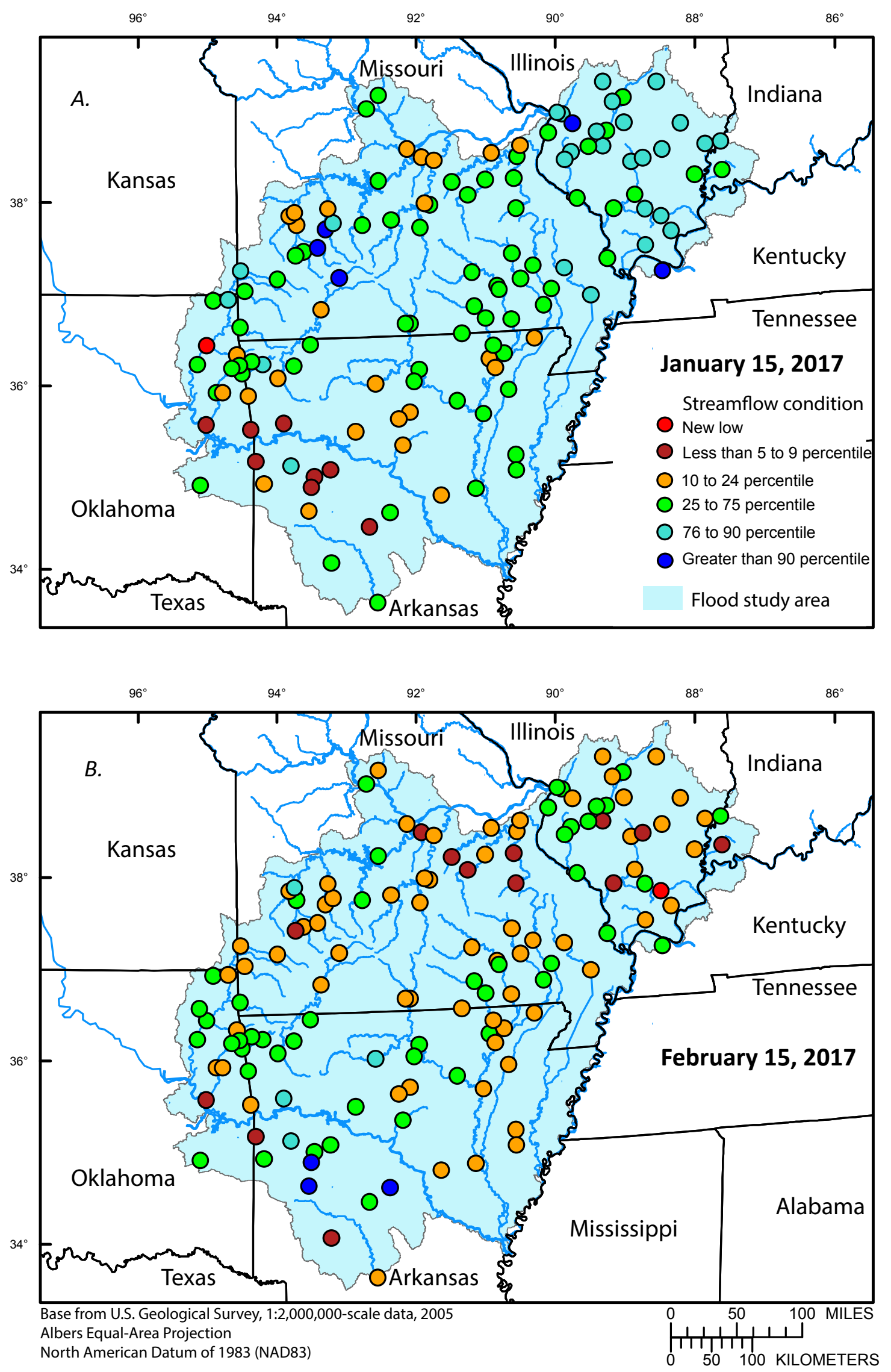

Figure 3. Streamflow conditions at selected U.S. Geological Survey streamgages in the study area before the April-May 2017 flooding including A, January ; B, February; C, March; and D, April of 2017. 

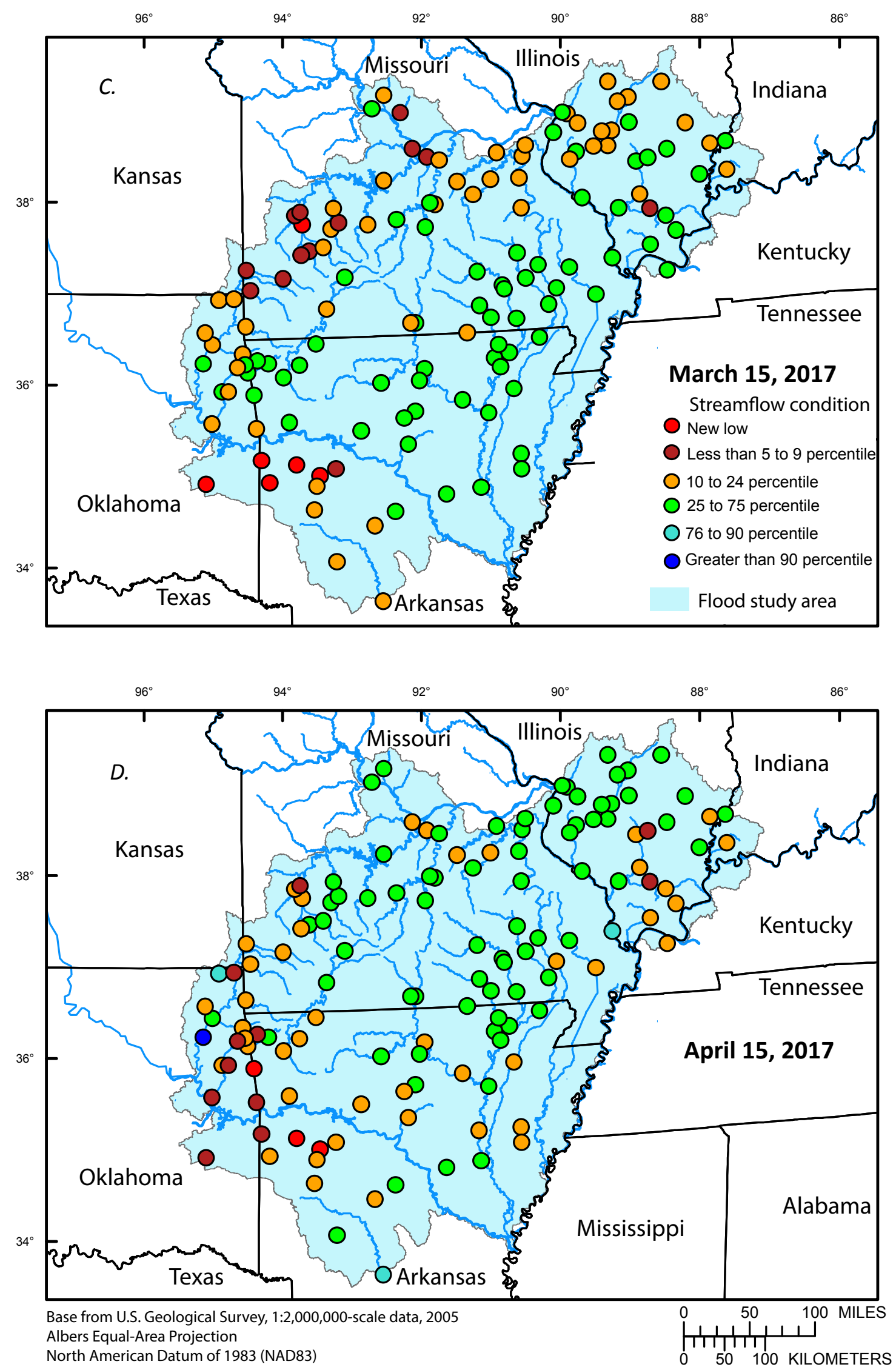

Figure 3. Streamflow conditions at selected U.S. Geological Survey streamgages in the study area before the April-May 2017 flooding including A, January; B, February; C, March; and D, April of 2017.-Continued 


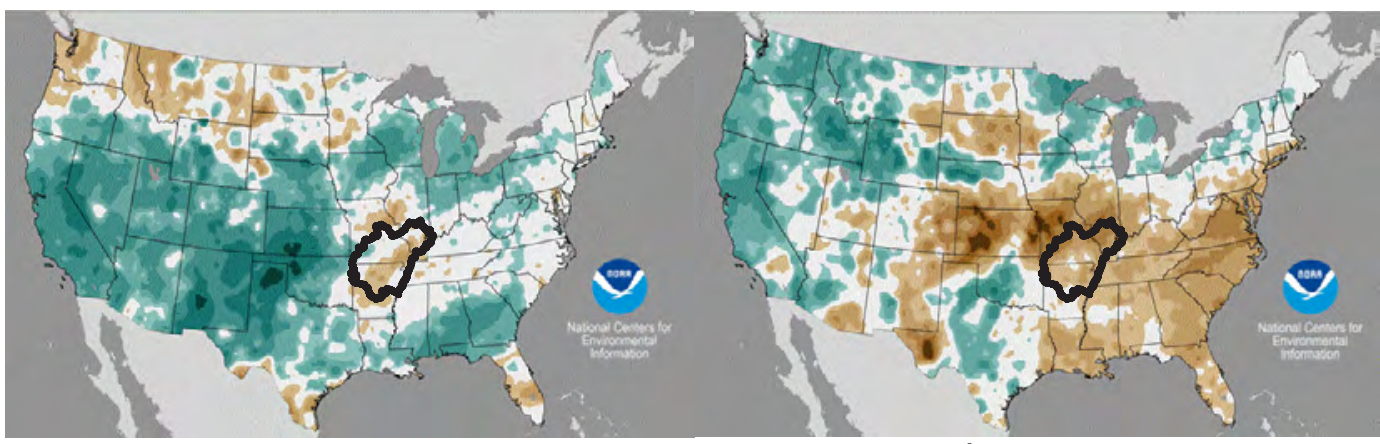

January 2017

February 2017

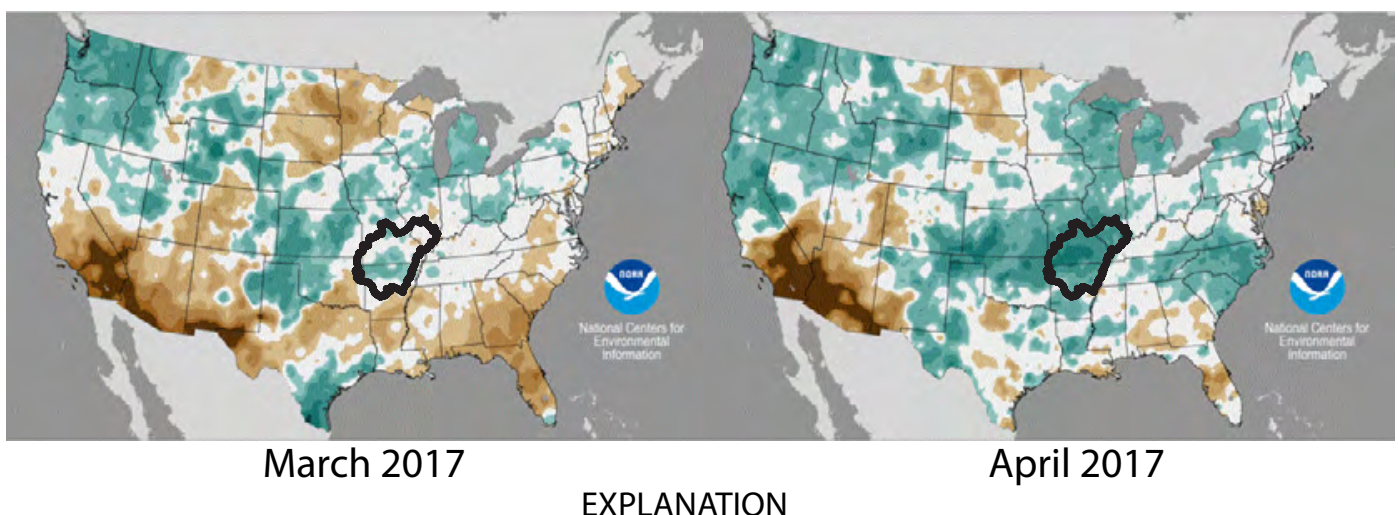

Monthly precipitation condition

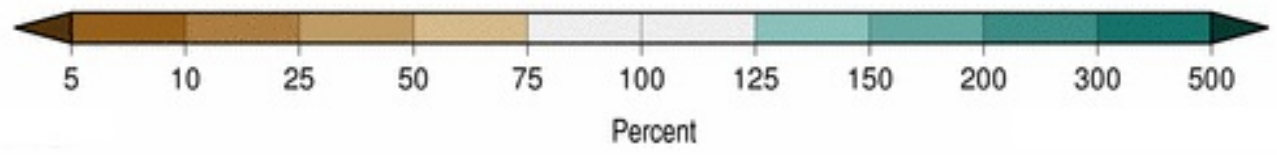

Study area boundary

Figure 4. Monthly precipitation conditions in the United States for January-April 2017, as a percent of normal. (Modified from NOAA, National Centers for Environmental Information, 2017b).

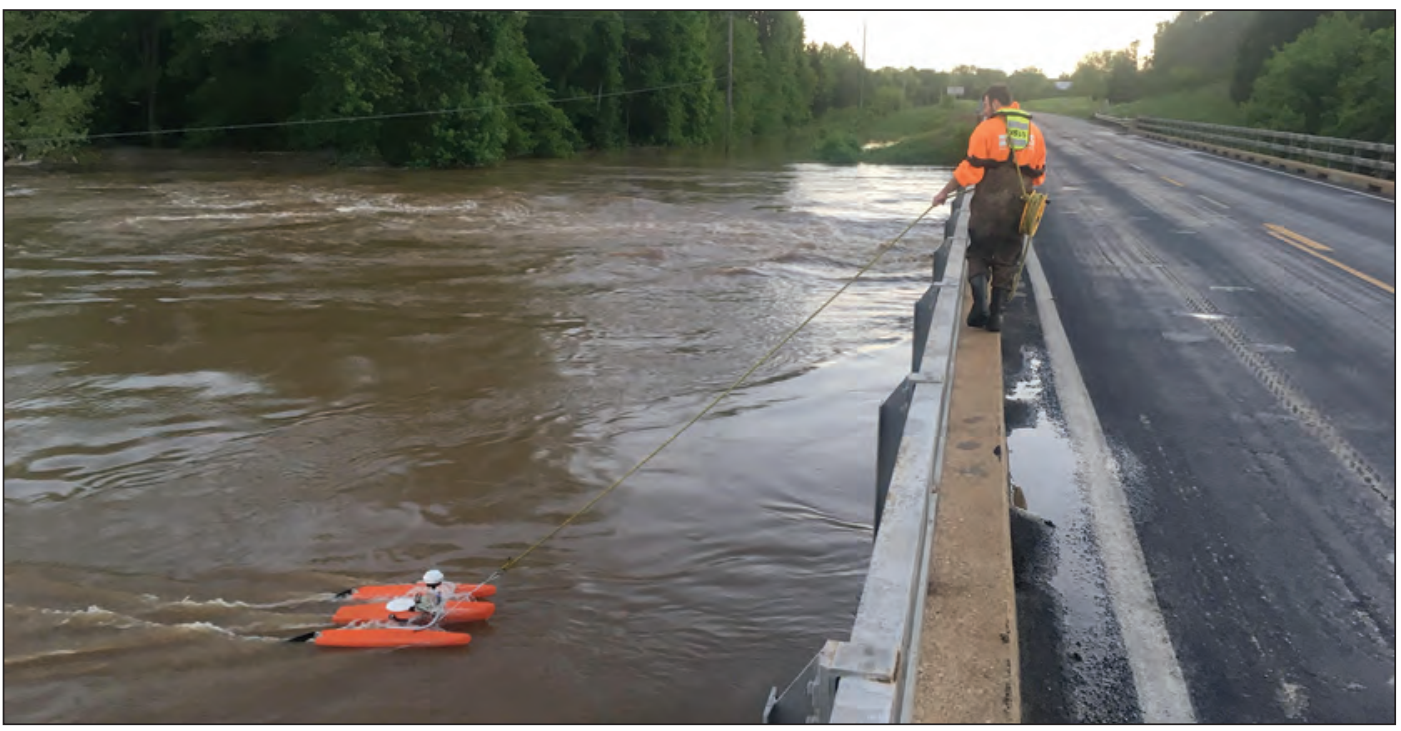

USGS hydrologic technician tethering acoustic Doppler current profiler (ADCP), St. Francis River near Patterson, Mo., April 30, 2017. Photograph by Aaron Walsh, USGS. 


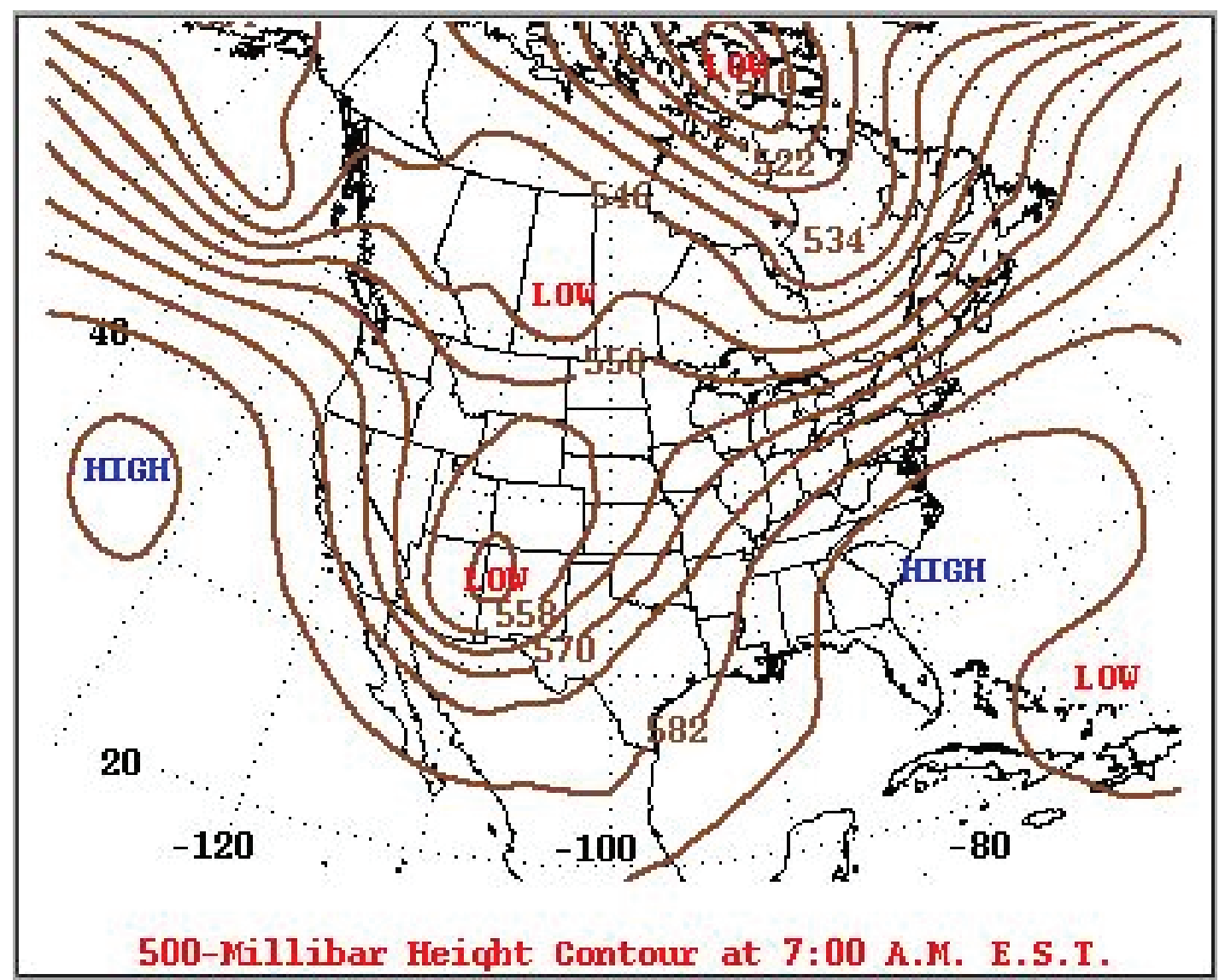

Figure 5. 500 millibar height contours for April 29, 2017, across the continental United States (Source: National Centers for Environmental Prediction, 2017).

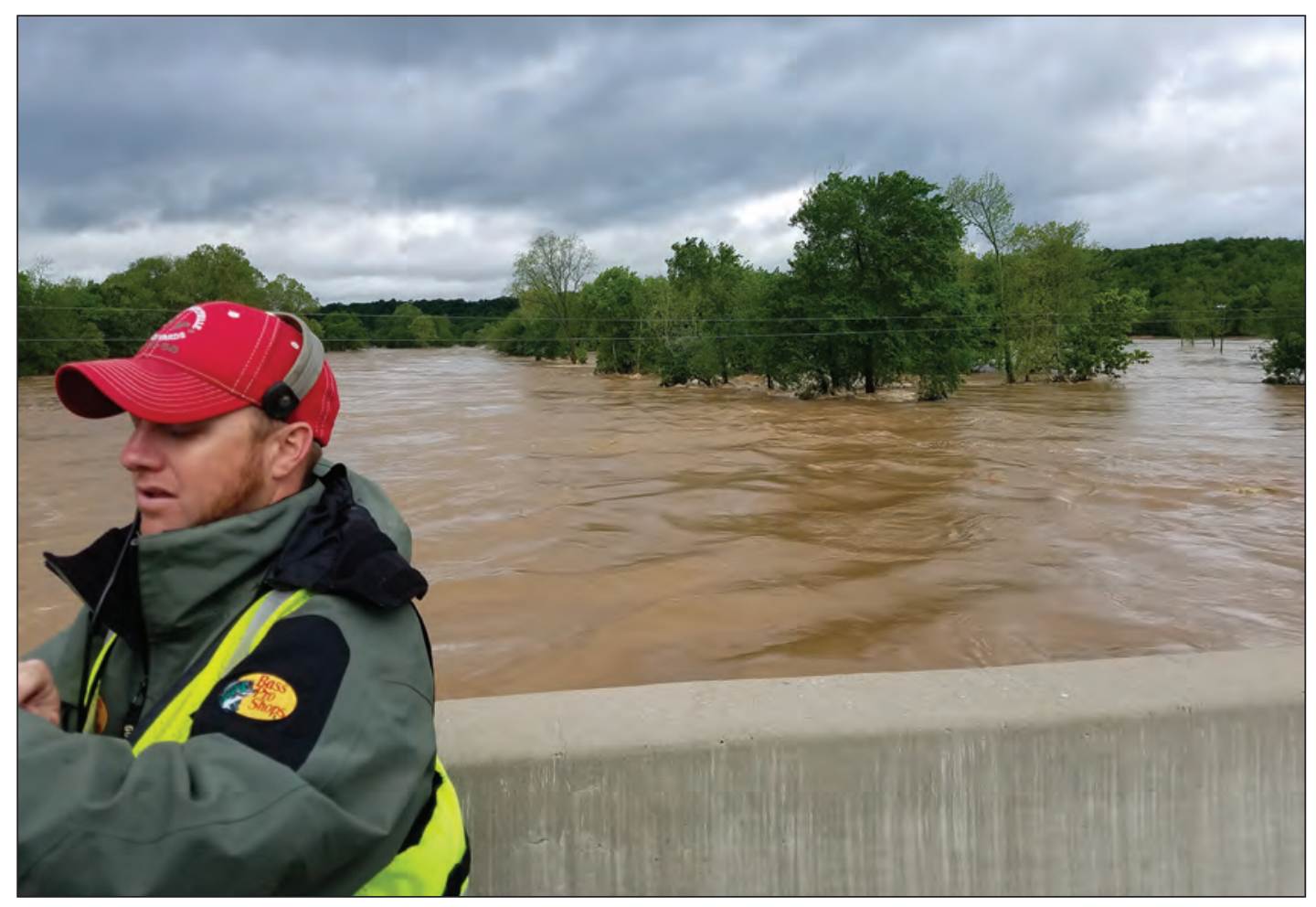

Illinois River near Watts, Okla., April 30, 2017. Photograph by U.S. Geological Survey. 

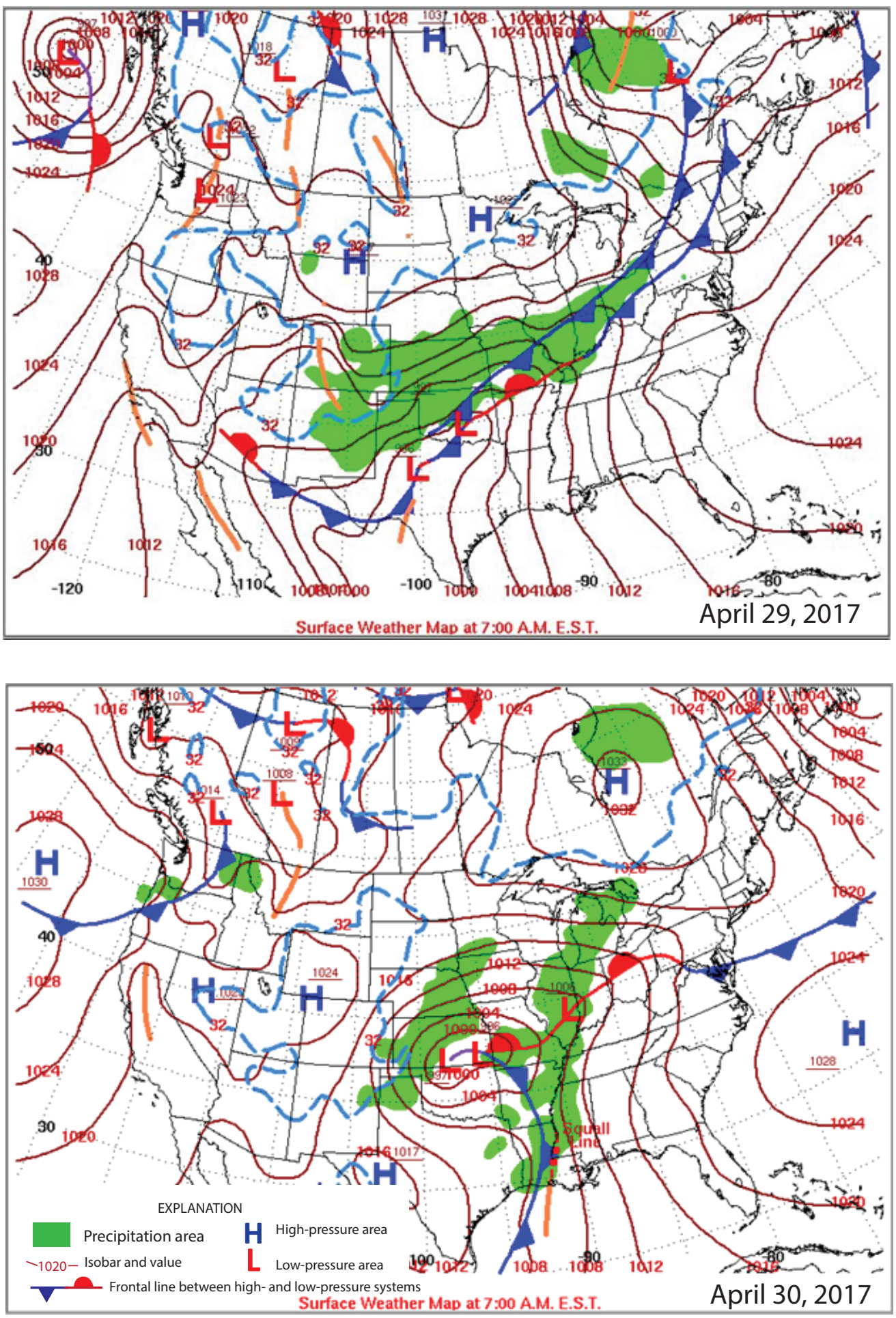

Figure 6. Daily surface weather maps at 7:00 AM Eastern Standard Time from April 29 to 30, 2017 (Source: National Centers for Environmental Prediction, 2017). 


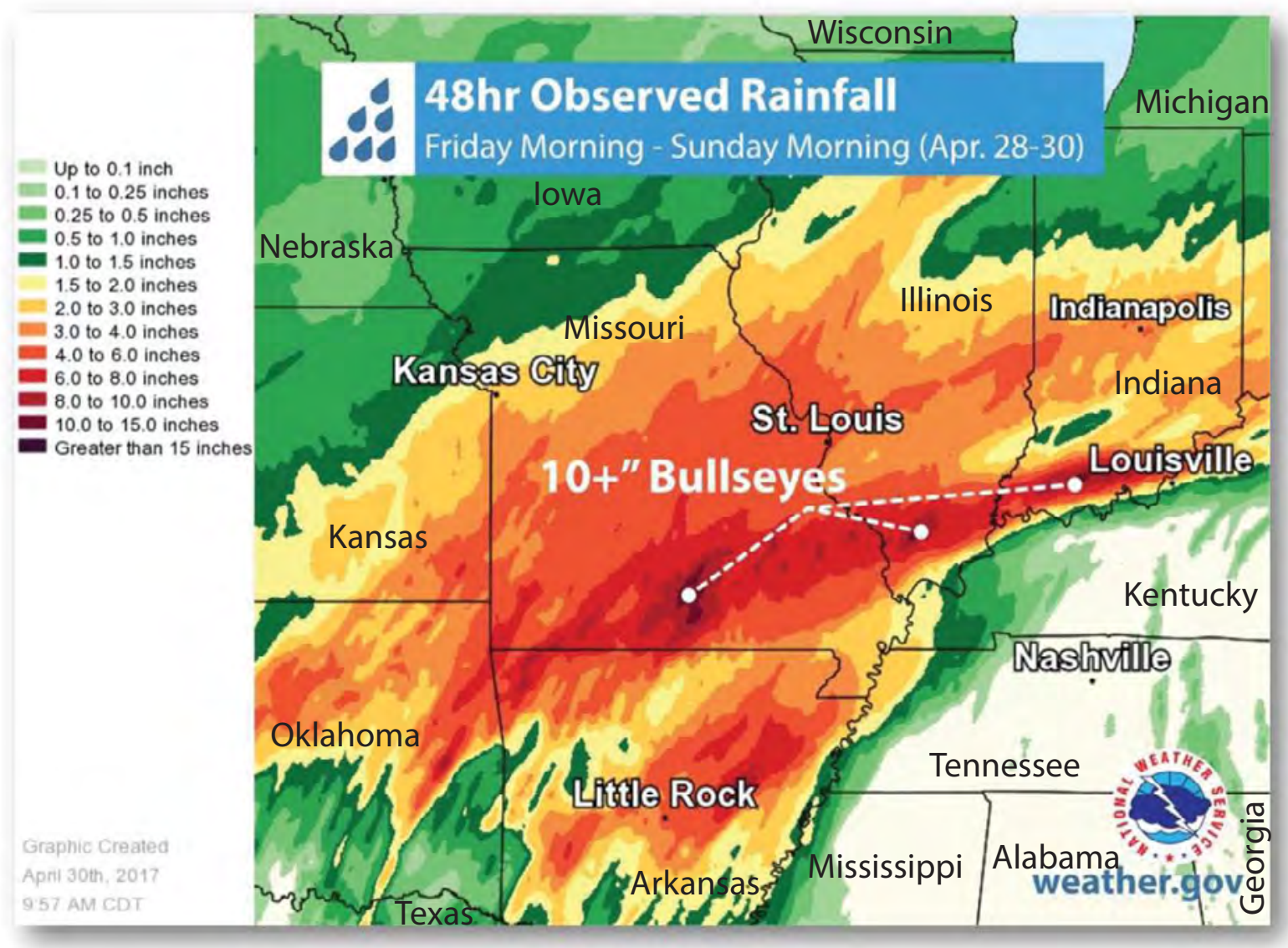

Figure 7. Cumulative rainfall totals over the southern Midwest United States during April 28-30, 2017. Source: National Weather Service (2017b).

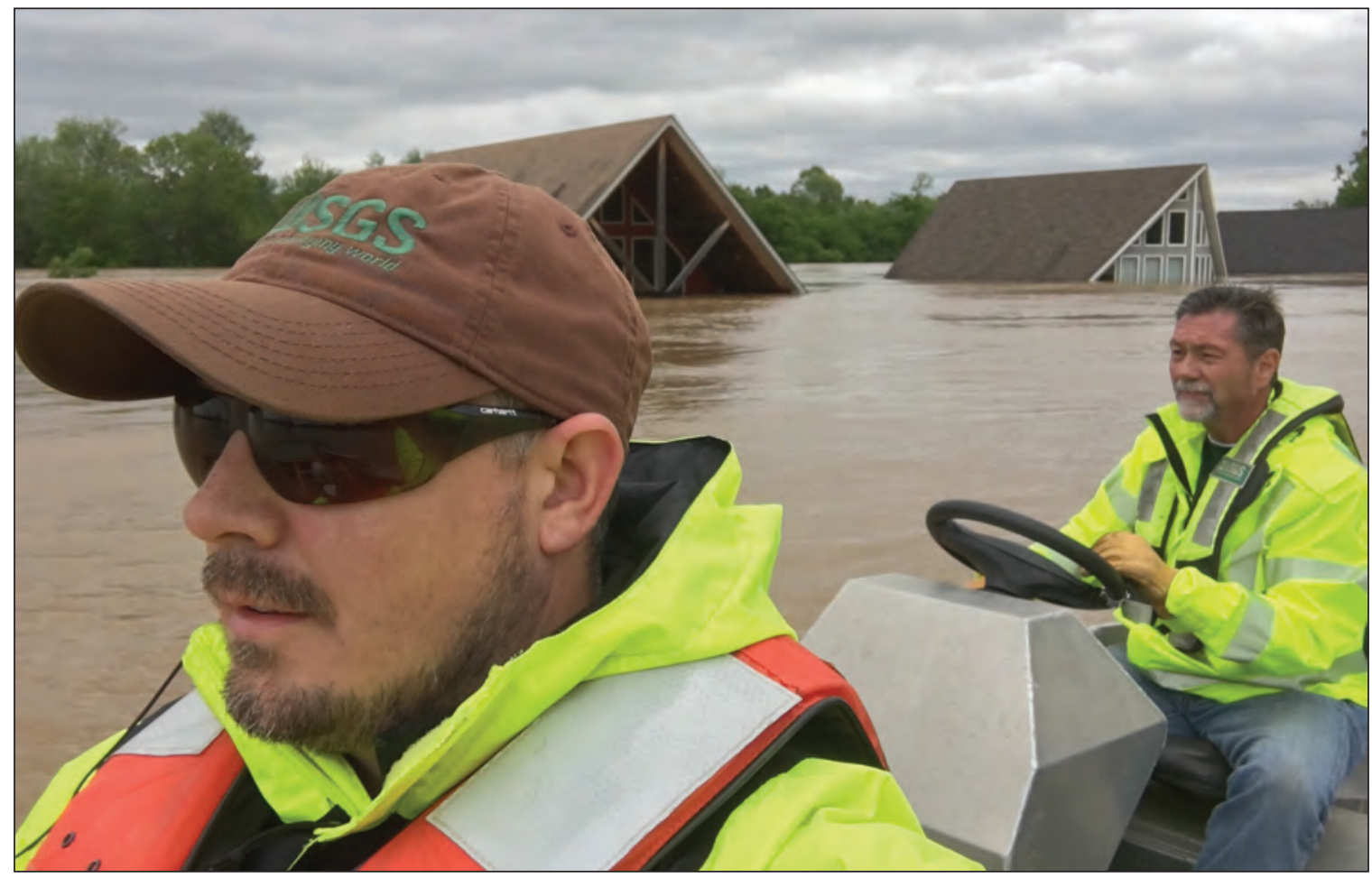

Southern Current River near Doniphan, Mo., May 1, 2017. Photograph by Ben Rivers, USGS. 


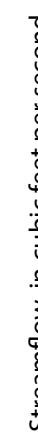
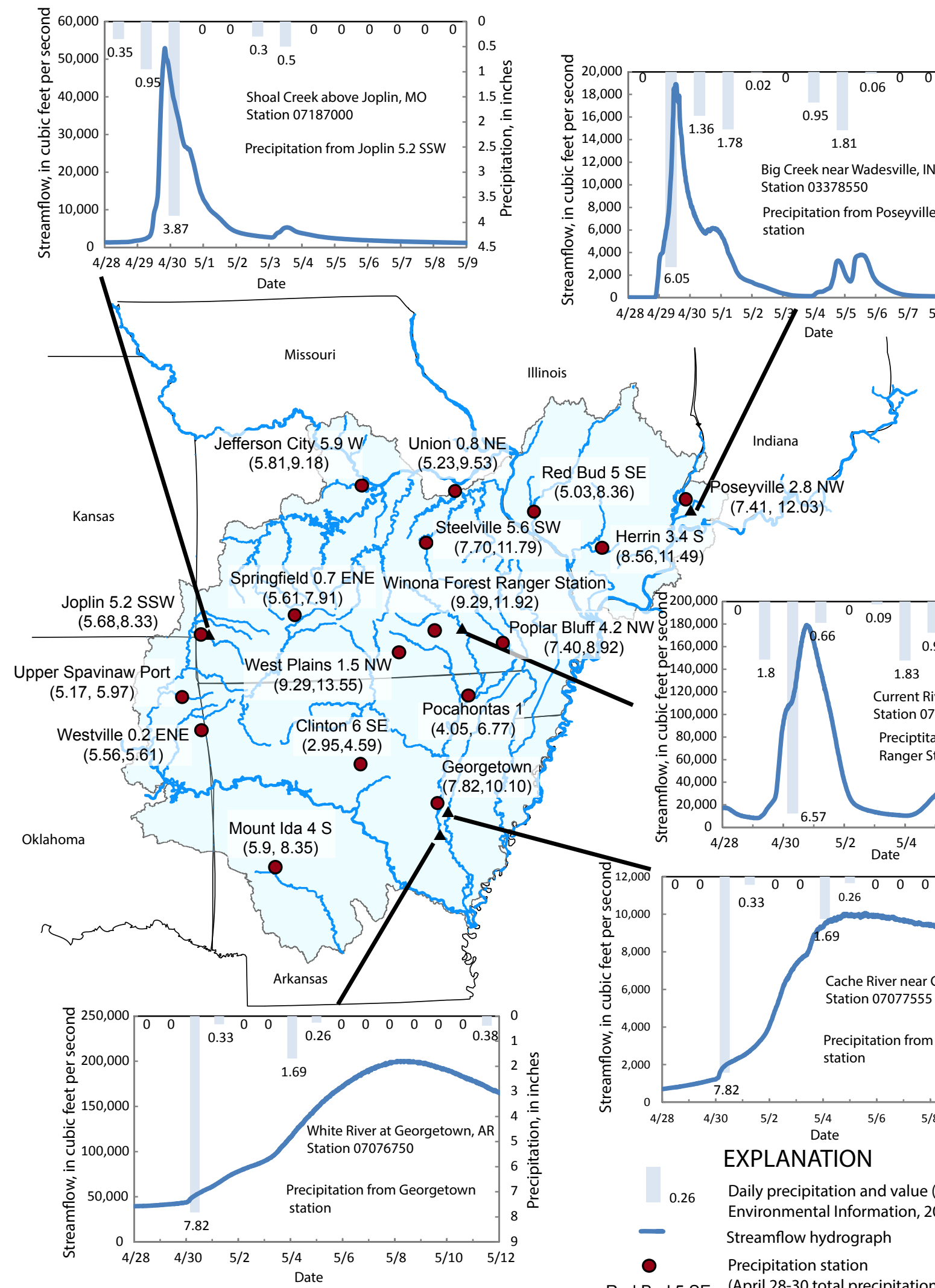

Figure 8. Streamflow hydrographs and precipitation totals and distributions for selected U.S. Geological Survey streamgages and precipitation stations within the study area.

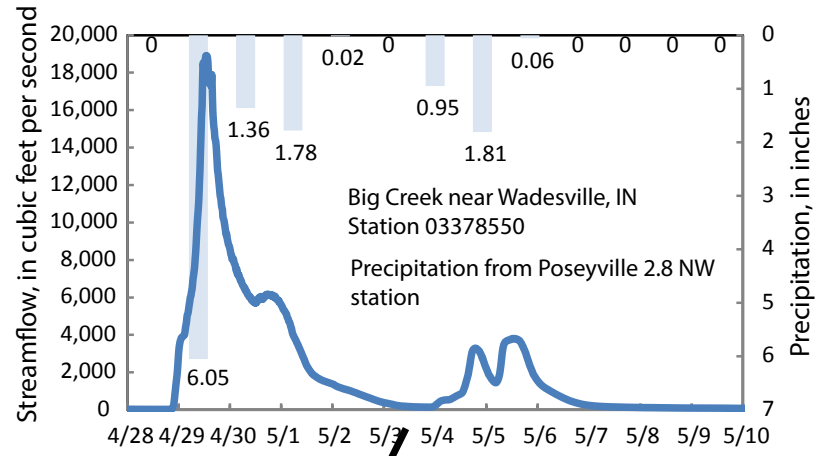

$\longrightarrow 0_{200,000}$
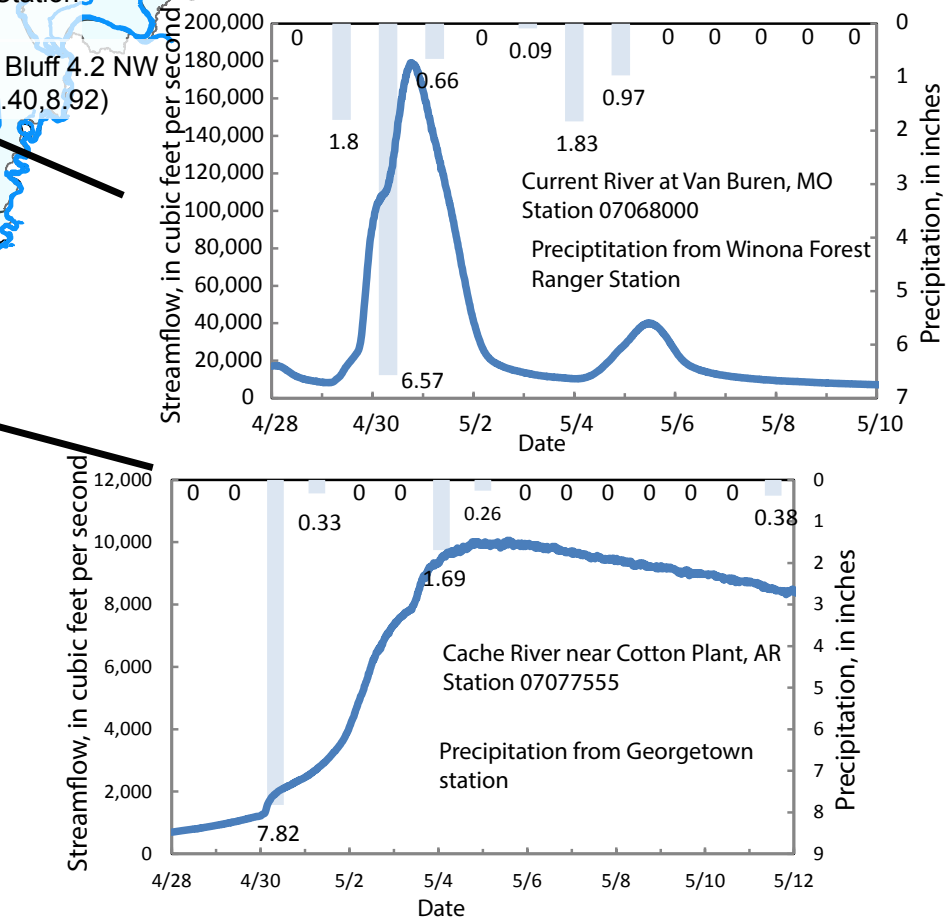

\section{EXPLANATION}

Daily precipitation and value (National Centers for Environmental Information, 2017a)

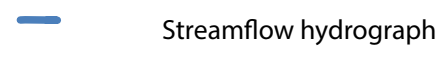

- Precipitation station

Red Bud 5 SE (April 28-30 total precipitation, $(5.03,8.36) \quad$ April 28-May 10 total precipitation, in inches) 


\section{Magnitude of April-May 2017 Flooding}

Peak-of-record streamflows were set at 21 USGS streamgages in the southern Midwest during the resulting April-May 2017 flooding (table 1). Each of the five States included in the study area had at least one streamgage with a peak of record during the flood. In Missouri, the previous peaks of record (for stage) at two rivers (Jacks Fork, Current River) had stood since 1904 and included 96 to 106 annual peaks. The peak stage of the April-May 2017 flood at the Current River at Van Buren, Mo. (station no. 07067000), exceeded the previous maximum stage by $8.4 \mathrm{ft}$ (table 1 ). Most remaining streamgages included in the study had peak streamflows during the event that ranked in the top three peaks of record. Additional USGS streamgages within the study area, but on the perimeter of the storm track, had peaks that ranked as low as the top 10-15 (table 1) including the Moniteau River near Fayette, Mo. (map identifier [ID] 7), and Cedar Creek near Pleasant View, Mo. (map ID 12), along the northern boundary of the study area (fig. 2).

Flooding is easily summarized numerically as a peak stage or streamflow value, but these numbers alone fail to convey the physical consequences of such high flows on structures and the lives of those affected. Aerial videos that were collected within 24 hours of the flood peaks at several locations (table 2, fig. 2) document the consequences of the floods (films 2-7). These videos were collected at locations within the greater than 10 in. precipitation areas shown in figure 7, and that also were near USGS streamgage locations with peaks of record during the flood including North Fork River near Tecumseh, Mo. (fig. 2 map ID 37; table 1) and Bryant Creek near Tecumseh, Mo. (fig. 2 map ID 38; table 1).

Film 2. Spring Creek at Highway AP bridge near Willow Springs, Missouri, April 30, 2017, at 10:30 a.m. (see fig. 2 aerial video location 1). (Video footage provided by Aerial Ozarks).

Film 3. North Fork River and Spring Creek at Highway 14, Douglas County, Missouri, April 30, 2017, at 12:09 p.m. (see fig. 2 aerial video location 2). (Video footage provided by Aerial Ozarks).

Film 4. North Fork River at Highway CC, Ozark County, Missouri, April 30, 2017, at 12:37 p.m. (see fig. 2 aerial video location 3). (Video footage provided by Aerial Ozarks).

Film 5. Bryant Creek at Highway 181, Ozark County, Missouri, April 30, 2017, at 13:06. (see fig. 2 aerial video location 4). (Video footage provided by Aerial Ozarks).

Film 6. North Fork River at Highway PP near Tecumseh, Missouri, Ozark County, April 30, 2017, at 13:40. (see fig. 2 aerial video location 5). (Video footage provided by Aerial Ozarks).

Film 7. Dry Creek at Highway AP near Willow Springs, Missouri, April 30, 2017, at 15:29. (see fig. 2 aerial video location 6). (Video footage provided by Aerial Ozarks).

Table 2. Date, times, and locations of aerial video footage documenting the effects of the April-May 2017 flood at selected locations in south-central Missouri.

[ID, identifier; Lat, lattitude; Long, longitude; hwy, highway; nr, near; MO, Missouri]

\begin{tabular}{ccccccc}
\hline Map ID (fig. 2) & Film & Lat & Long & Date & Time & Description \\
\hline 2 & 2 & 36.9074051 & -92.0808668 & $4 / 30 / 2017$ & $10: 30$ & $\begin{array}{c}\text { Spring Creek at Hwy AP bridge, nr Willow Springs, } \\
\text { MO. }\end{array}$ \\
3 & 3 & 36.810436 & -92.1498827 & $4 / 30 / 2017$ & $112: 09$ & $\begin{array}{c}\text { North Fork River and Spring Creek at Hwy 14, } \\
\text { Douglas County, MO. }\end{array}$ \\
4 & 4 & 36.7598273 & -92.1556513 & $4 / 30 / 2017$ & $112: 37$ & $\begin{array}{c}\text { North Fork River at Hwy CC, Ozark County, MO. } \\
5\end{array}$ \\
6 & 5 & 36.7095049 & -92.2690143 & $4 / 30 / 2017$ & ${ }^{2} 13: 06$ & $\begin{array}{c}\text { Bryant Creek at Highway 181, Ozark County, MO. } \\
\text { North Fork River at Hwy PP nr Tecumseh, Ozark } \\
\text { County, MO. }\end{array}$ \\
7 & 7 & 36.615802 & -92.262483 & $4 / 30 / 2017$ & ${ }^{1} 13: 40$ & $\begin{array}{c}130 \\
\text { Dry Creek at Highway AP, near Willow Springs, } \\
\text { Howell County, MO. }\end{array}$ \\
\hline
\end{tabular}

${ }^{1}$ The peak at the nearby North Fork River near Tecumseh, Missouri, streamgage was at 4/29/17 at 21:45.

${ }^{2}$ The peak at the nearby Bryant Creek near Tecumseh, Missouri, streamgage was at 4/29/17 at 20:00. 


\section{April-May 2017 Flooding-Comparison with Historic Floods}

Placing the magnitude of a flood into context is desirable for comparison with previous floods. Ranking the observed 2017 peak streamflows at USGS streamgages against previous streamflow peaks of record indicates the relative magnitude of the 2017 floods (table 1, fig. 9). The benchmark for major flooding on many of the major tributaries in the study area includes the 1982 (Sauer and Fulford, 1983), 1993 (Parret and others, 1993), and December-January 2015-16 floods (Holmes and others, 2016). Each of the 1982, 1993, and 2015-16 floods resulted in 8 peaks of record among the selected stations included in this study, whereas the 2017 flood resulted in 21 peaks of record. The number of streamgages in operation did vary considerably with time, but nearly the same number of streamgages were in operation in 1982 (54 streamgages) as were in operation during the 1993, 2015-16, and 2017 floods (59 streamgages; fig. 9).

\section{April-May 2017 Flooding-Annual Exceedance Probability}

In the past, flood-frequency estimates have been presented in terms of the recurrence interval, which represents the average number of years between occurrences of a streamflow of equal or greater magnitude. This term, however, often results in a misunderstanding that a 100-year flood, once it has occurred, will not occur again for another 99 years, which is not necessarily true. A 100-year flood means that, if all things remain the same in the basin (for example, land use and climate conditions), the observed annual floods during thousands of years would average around 100 years between events of this magnitude. The term annual exceedance probability (AEP) is now more commonly used to refer to floodfrequency estimates because it more clearly conveys that the flood-frequency estimates are probabilistic in nature. The AEP is the probability that the streamflow of a certain magnitude will be equaled or exceeded in any year and is the reciprocal of the recurrence interval. A 0.01 AEP streamflow, for example, has a 1-percent chance of occurring in any year and is equivalent to a 100-year flood streamflow.

The current (2017) standard methodology for the determination of flood-frequency studies is Bulletin 17C (England and others, 2017) of the Advisory Committee on Water Information. Similar to the Bulletin 17B method (Interagency Advisory Committee on Water Data, 1982), the Bulletin 17C method fits a log-Pearson Type III distribution curve to the logarithms of annual peak discharges at a given station using the method-of-moments to compute a mean, standard deviation, and station skew of the log-transformed peak flow data. The user has the option to weigh the individual station skew estimate with a generalized/regional skew estimate, which typically improves the accuracy because skews tend to follow regional trends. Modifications incorporated into the Bulletin $17 \mathrm{C}$ method include the adoption of a generalized methodof-moments estimator, known as the expected moments algorithm (EMA) procedure (Cohn and others, 1997), and a generalized version of the Grubbs-Beck test for low outliers

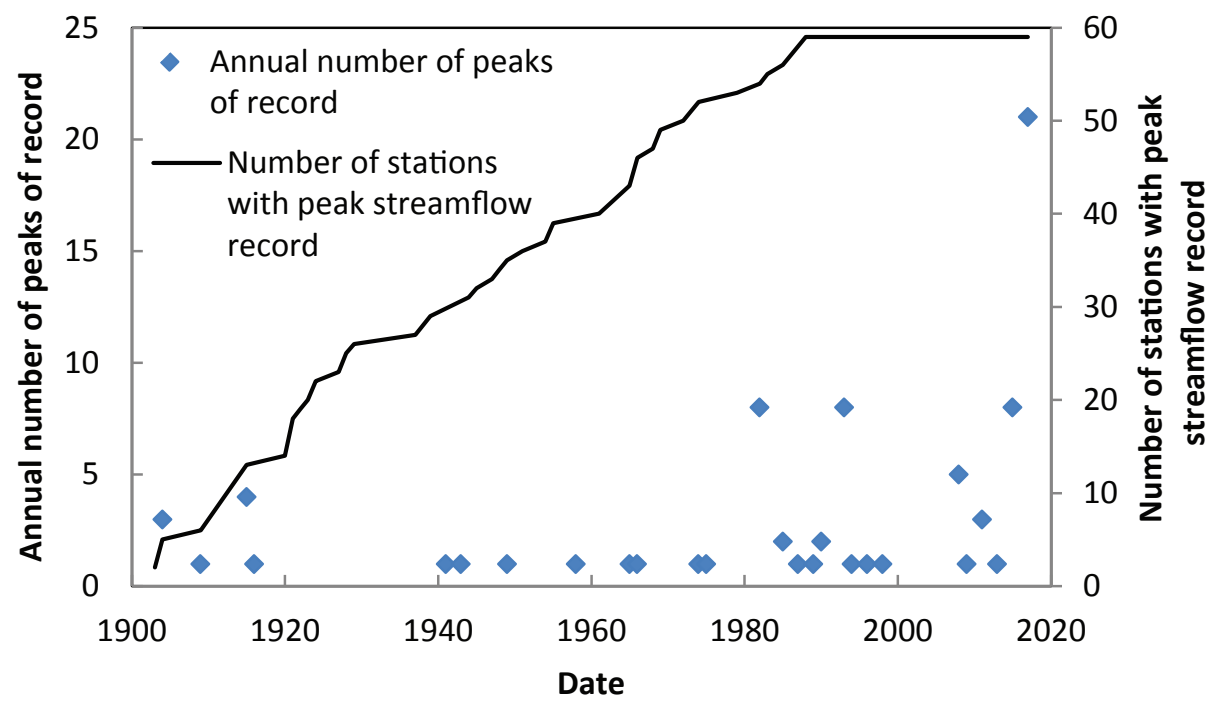

Figure 9. Annual number of peak-of-record streamflows and number of U.S. Geological Survey streamgages in the study area with peak streamflow record. 
(Cohn and others, 2013). The EMA is an updated method for fitting the log-Pearson Type III frequency distribution that is a more effective means of incorporating historical peak streamflow information into a flood-frequency analysis.

The USGS computer program PEAKFQ (version 7.1; Flynn and others, 2006) was used to compute the floodfrequency estimates for the 59 stations in this study. The annual peak streamflow data used in the analyses were obtained from U.S. Geological Survey (2017a). The program automates many of the flood-frequency analyses procedures, including identifying and adjusting for high and low outliers and historical periods and fitting the log-Pearson Type III distribution to the streamflow data. The program includes the EMA procedure for flood-frequency analysis and multiple Grubbs-Beck outlier screening (Veilleux and others, 2013). The PEAKFQ program and associated documentation are available at https://water.usgs.gov/software/peakfq.html.

In addition to estimating the at-site AEP flood quantiles by Bulletin 17C methods, another way to obtain an AEP flood quantile estimate is by using regional regression equations (RREs). The RREs are developed using regression techniques that relate the peak flood-probability data at many streamgages in a particular region to the basin characteristics upstream from the streamgages (Jennings and others, 1994). The RREs allow a user to estimate the various AEP flood quantiles for any location along a stream (gaged or ungaged) by entering the specified basin characteristics (for example, drainage area or average precipitation) used as independent variables in the equation. Rural regression estimates for the 59 streamgages in this study were obtained from the corresponding RRE estimates developed for each state in the study area including Arkansas (Wagner and others, 2016), Illinois (Soong and others, 2004), Missouri (Southard, 2010; Southard and Veilleux, 2014), and Oklahoma (Lewis, 2010). The single streamgage in Indiana (Big Creek near Wadesville, Indiana) is within $10 \mathrm{mi}$ of the Illinois border, so the Illinois RRE equations were used to obtain the RRE estimates for this station. The optimal estimate of the AEP flood quantile for a gaged site is determined by weighting the at-site AEP flood quantile estimate determined from the Bulletin 17C methods with the AEP flood quantile estimate determined from the RRE as described in (Soong and others, 2004; Southard, 2010; Southard and Veilleux, 2014; and Wagner and others, 2016).

The AEP estimates for the April-May 2017 flood peak streamflows indicate that peaks at 5 USGS streamgages had an AEP of 0.2 percent or less, and peak streamflows at 15 USGS streamgages had an AEP in the range from greater than 0.2 to 1 percent (table 3, fig. 10). The weighted estimates of the AEP flood quantiles corresponding to the 50-, 20-, 10-, 4-, 2-, 1-, 0.5-, and 0.2-percent AEPs, along with their respective 95-percent confidence limits, for the selected 59 streams in the southern Midwest included in this study, also were computed (table 3).

\section{Temporal Changes in Annual Peak Streamflows}

Temporal changes in annual peak streamflows are important to investigate because they may indicate to emergency and infrastructure managers there are corresponding changes in the levels of risk to public safety. Temporal changes in streamflow can be the result of changes to such factors as land use and land cover, climate, or regulation. The annual peak streamflow time series data were analyzed for selected streamgages in the southern Midwest to determine the presence and subsequent magnitude of changes through time at each site.

The temporal changes in streamflow magnitudes were computed based on the Sen's slope estimator (Sen, 1968) using the MAKESENS application from the Finnish Meteorological Institute (Salmi and others, 2002). The Sen's slope, also known as the Kendall-Theil robust line, is a nonparametric estimate of trend magnitude slope for a univariate time series when the time interval is constant (equally spaced).

$$
f(t)=M q \times t+B
$$

where

$$
\begin{aligned}
& f(t) \text { is the increasing or decreasing function } \\
& \text { of time for the trend magnitudes of the } \\
& \text { streamflows used in the investigation, } \\
& M q \text { is the Sen's slope estimate, } \\
& t \text { is time, and } \\
& B \text { is a constant. }
\end{aligned}
$$

The Sen's slope is the median slope of all pairwise comparisons with each pairwise difference divided by the number of years separating the records. To determine the Sen's slope estimate in equation 2 , the slopes of all data pairs are calculated:

$$
M_{j, k}=\frac{\left(X_{k}-X_{j}\right)}{\Delta t_{j, k}} \text { for } j=1, \ldots, \mathrm{n}-1 ; j<k \leq \mathrm{n}
$$

where

$$
\begin{aligned}
M_{j, k} & \text { is the slope between data points } X_{j} \text { and } X_{k} ; \\
X_{j} & \text { is the data measurement at time } j ; \\
X_{k} & \text { is the data measurement at time } k ; \\
\Delta t_{j, k} & \text { is the change in time between observations; } \\
& \text { and } \\
\mathrm{n} & \text { is the number of years of record. }
\end{aligned}
$$

The Sen's slope estimate, $M_{q}$, is equal to the median value of all the $M_{j, k}^{q}$ values. 
Streamgages with missing record periods exceeding 5 percent of the total record were not used in the analyses of temporal changes in annual streamflow peaks nor were streamgages on regulated rivers. Of the 59 streamgages included in the study, 49 were used in the analyses of temporal changes in annual peak streamflows. The start dates of documented peak streamflows and record periods for the 49 stations differed; therefore, four temporal analysis periods (1930-2017, 1956-2017, 1975-2017, and 1989-2017) were selected to maintain consistency in streamflow record start dates, have overlap of record analysis periods, and maximize the number of stations and the period of record that could be included in the analyses. For comparison of streamgages with differing basin sizes, the Sen's slope for each streamgage was divided by the median annual peak streamflow value to determine the percentage of change with respect to the median annual peak streamflow at each streamgage.

Examination of the magnitude of the temporal changes (scaled by median annual peak flood streamflow) in median annual peak streamflows from 1930-2017 indicates all but 1 of the 20 stations included had a systematic positive increase in peak streamflows of less than 2 percent per year (fig. 11A). The remaining station, Shoal Creek above Joplin, Mo. (station no. 07187000, map ID 53), had a negative change of -0.12 percent per year during the analysis period. Similarly, the temporal change in peak streamflows at most of the 34 stations included in the 1956-2017 analysis period had median positive increases in annual peak flows of less than 2 percent (fig. 11B). Two stations (Jacks Fork at Eminence, Mo., station no. 07066000, map ID 41; Current River at Van Buren, Mo., station no. 07067000, map ID 42), had no change and one station had a median decrease in annual peak streamflows of -0.12 percent per year over the 61 -year period (Cadron Creek near Guy, Ark., station no. 07261000, map ID 58). Analyses of the 1975-2017 and 1989-2017 periods indicated nearly all stations had median positive changes in annual peak streamflows of increasing magnitude (fig. 11C). Six of the 44 stations in the 1975-2017 analysis period had positive changes of greater than 2 percent, whereas 23 of 49 stations in the 1989-2017 analysis period had median positive increases of greater than 2 percent with maximum increases of 8-10 percent per year (fig. 11D). No stations in either of the 1975-2017 or 1989-2017 analysis periods had median negative changes in peak streamflows, but five stations in the 1989-2017 analysis period had no change in streamflow peaks.

A primary driver of change in peak streamflows is precipitation. Similar to streamflow peaks, the annual precipitation within the flood study area was analyzed by climate division (NOAA, National Centers for Environmental Information, 2017c) using the Sen's slope methodology. Changes in annual precipitation were analyzed for the same periods as peak streamflow except the analysis periods for precipitation ended in 2016. Similar to changes in annual peak streamflows, median changes in annual precipitation for the 1930-2016 and 1956-2016 periods generally were small (less than 2 percent) and positive (fig. 12). Changes in annual precipitation, however, provided little explanation for the substantial increase in magnitude of streamflow peaks because, for example, nearly one-half of the climate divisions in the 19892016 analysis period indicated no change or a negative change in precipitation per year, whereas this was the period of the greatest magnitude in positive changes in streamflow peaks in the study area. The increase in the frequency of larger magnitude rain events with time may be a better explanatory variable for the greater positive changes in annual peak streamflows. The frequency of daily precipitation events of greater than 2 or 3 in. generally increased from 1985 to 2014 in each state in the study area (fig. 13). The degree to which land use changes may have contributed to the positive changes in peak streamflows was undetermined. 
Table 3. Estimated annual exceedance probability of the 2017 flood peaks and weighted peak streamflow estimates for selected flood quantiles at 59 U.S. Geological Survey streamgages included in this study.

[ID, identifier; USGS, U.S. Geological Survey; AEP, annual exceedance probability; ft, foot; $\mathrm{ft}^{3} / \mathrm{s}$, cubic foot per second; \%, percent; --, not calculated; stations with peak of record during April-May 2017 flood are shown with rank value of "1" in bold]

\begin{tabular}{|c|c|c|c|c|c|c|c|c|c|c|c|c|c|c|c|c|c|}
\hline \multirow{4}{*}{ 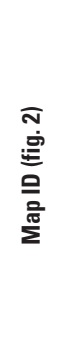 } & \multirow{4}{*}{ 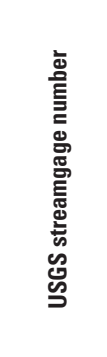 } & \multirow{4}{*}{ 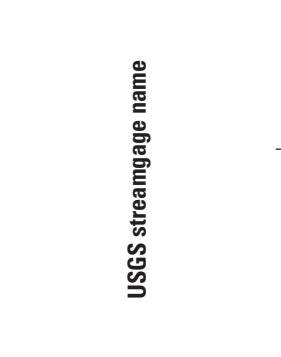 } & \multirow{2}{*}{\multicolumn{5}{|c|}{2017 flood peak }} & \multirow{2}{*}{\multicolumn{4}{|c|}{ AEP for observed 2017 flood }} & \multicolumn{6}{|c|}{$\begin{array}{c}\text { Expected peak streamflows for selected AEP with } \\
\text { 95-percent confidence limits }\left(\mathrm{ft}^{3} / \mathrm{s}\right)\end{array}$} \\
\hline & & & & & & & & & & & & $\begin{array}{r}50 \\
(2-y e\end{array}$ & $\begin{array}{l}\text { percent } A \\
\text { ar recurre }\end{array}$ & $\begin{array}{l}\text { AEP } \\
\text { ence) }\end{array}$ & & -percent 1 & AEP \\
\hline & & & \multirow[b]{2}{*}{ 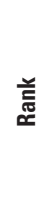 } & \multirow{2}{*}{ 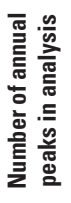 } & \multirow{2}{*}{ 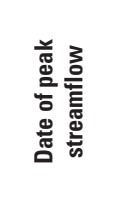 } & \multirow{2}{*}{ 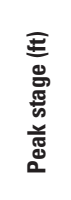 } & \multirow{2}{*}{ 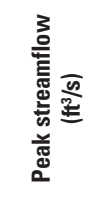 } & \multirow{2}{*}{ 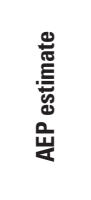 } & \multirow{2}{*}{ 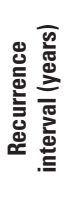 } & \multicolumn{2}{|c|}{$\begin{array}{l}67 \% \text { confidence } \\
\text { interval' }\end{array}$} & \multirow{2}{*}{ 离 } & \multicolumn{2}{|c|}{$\begin{array}{l}95 \% \text { confidence }^{\text {limits }^{2}}\end{array}$} & \multirow{2}{*}{ 离 } & \multicolumn{2}{|c|}{$\begin{array}{l}\text { 95\% confidence } \\
\text { limits }^{2}\end{array}$} \\
\hline & & & & & & & & & & 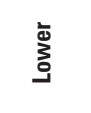 & 言 & & $\overbrace{0}^{\grave{a}}$ & 흥 & & $\sum_{0}^{ \pm 0}$ & 产 \\
\hline 1 & 03378550 & $\begin{array}{l}\text { Big Creek near } \\
\text { Wadesville, Indiana }\end{array}$ & 1 & 52 & $4 / 29 / 2017$ & 21.23 & 19,000 & $0.83 \%$ & 123 & $0.4 \%$ & $3.4 \%$ & 5,270 & 4,710 & 5,890 & 7,920 & 6,930 & 9,050 \\
\hline 2 & 03382100 & $\begin{array}{l}\text { South Fork Saline River } \\
\text { near Carrier Mills, } \\
\text { Illinois }\end{array}$ & 2 & 52 & $4 / 30 / 2017$ & 17.14 & 12,200 & $1.4 \%$ & 72 & $1.4 \%$ & $6.1 \%$ & 3,100 & 2,720 & 3,520 & 5,030 & 4,310 & 5,880 \\
\hline 3 & 03612000 & $\begin{array}{l}\text { Cache River at Forman, } \\
\text { Illinois }^{3}\end{array}$ & 3 & 95 & $5 / 2 / 2017$ & 36.55 & 11,200 & $3.8 \%$ & 27 & $1.5 \%$ & $4.7 \%$ & 3,810 & 3,430 & 4,230 & 6,320 & 5,620 & 7,100 \\
\hline 4 & 05587900 & $\begin{array}{l}\text { Cahokia Creek at } \\
\text { Edwardsville, Illinois }\end{array}$ & 3 & 49 & $5 / 1 / 2017$ & 23.08 & 9,090 & $7.3 \%$ & 14 & $2.9 \%$ & $9.1 \%$ & 5,470 & 5,030 & 5,950 & 7,350 & 6,700 & 8,050 \\
\hline 5 & 05595200 & $\begin{array}{l}\text { Richland Creek near } \\
\text { Heckler, Illinois }\end{array}$ & 3 & 48 & $4 / 30 / 2017$ & 43.06 & 16,000 & $4.9 \%$ & 20 & $2.9 \%$ & $9.2 \%$ & 5,900 & 5,070 & 6,870 & 9,920 & 8,460 & 11,600 \\
\hline 6 & 05597500 & $\begin{array}{l}\text { Crab Orchard Creek near } \\
\text { Marion, Illinois }\end{array}$ & 1 & 66 & $4 / 29 / 2017$ & 13.84 & 10,300 & $0.91 \%$ & 110 & $0.3 \%$ & $2.7 \%$ & 1,950 & 1,670 & 2,260 & 3,600 & 3,030 & 4,270 \\
\hline 7 & 06909500 & $\begin{array}{r}\text { Moniteau Creek near } \\
\text { Fayette, Missouri }\end{array}$ & 15 & 60 & $4 / 30 / 2017$ & 19.71 & 4,010 & $27.9 \%$ & 4 & $19.3 \%$ & $29.9 \%$ & 2,830 & 2,500 & 3,200 & 4,600 & 4,010 & 5,270 \\
\hline 8 & 06910230 & $\begin{array}{l}\text { Hinkson Creek at } \\
\quad \text { Columbia, Missouri }{ }^{4}\end{array}$ & 6 & 31 & $4 / 29 / 2017$ & 19.21 & 9,300 & $10.1 \%$ & 10 & $12.1 \%$ & $25.3 \%$ & 4,560 & 3,880 & 5,360 & 7,400 & 6,360 & 8,610 \\
\hline 9 & 06910750 & $\begin{array}{l}\text { Moreau River near } \\
\text { Jefferson City, } \\
\text { Missouri }\end{array}$ & 2 & 58 & $5 / 1 / 2017$ & 33.57 & 32,900 & $3.1 \%$ & 32 & $1.3 \%$ & $5.5 \%$ & 13,600 & 12,100 & 15,300 & 20,600 & 18,300 & 23,300 \\
\hline 10 & 06918440 & $\begin{array}{l}\text { Sac River near Dadeville, } \\
\quad \text { Missouri }\end{array}$ & 4 & 53 & $4 / 30 / 2017$ & 21.85 & 18,400 & $7.3 \%$ & 14 & $4.1 \%$ & $10.7 \%$ & 5,270 & 4,420 & 6,290 & 10,500 & 8,650 & 12,800 \\
\hline 11 & 06919020 & $\begin{array}{l}\text { Sac River at Highway J } \\
\text { below Stockton, } \\
\text { Missouri }^{5}\end{array}$ & 4 & 44 & $4 / 30 / 2017$ & 22.36 & 11,400 & $6.6 \%$ & 15 & $4.9 \%$ & $12.8 \%$ & 6,860 & 6,120 & 7,650 & 9,120 & 8,180 & 10,400 \\
\hline 12 & 06919500 & $\begin{array}{l}\text { Cedar Creek near Pleasant } \\
\text { View, Missouri }\end{array}$ & 10 & 74 & $4 / 30 / 2017$ & 24.81 & 21,000 & $13.5 \%$ & 7 & $9.6 \%$ & $17.1 \%$ & 9,880 & 8,640 & 11,300 & 17,500 & 15,200 & 20,000 \\
\hline 13 & 06919900 & $\begin{array}{l}\text { Sac River near Caplinger } \\
\text { Mills, Missouri }\end{array}$ & 6 & 43 & $4 / 30 / 2017$ & 28.39 & 33,300 & $14.1 \%$ & 7 & $8.7 \%$ & $18.5 \%$ & 15,300 & 11,900 & 19,300 & 27,900 & 22,200 & 36,500 \\
\hline 14 & 06921070 & $\begin{array}{l}\text { Pomme de Terre River } \\
\text { near Polk, Missouri }\end{array}$ & 3 & 49 & $4 / 30 / 2017$ & 24.68 & 27,600 & $5.4 \%$ & 18 & $2.9 \%$ & $9.1 \%$ & 13,400 & 11,900 & 15,100 & 19,800 & 17,600 & 22,200 \\
\hline 15 & 06923500 & $\begin{array}{l}\text { Bennett Spring at Bennett } \\
\text { Springs, Missouri }{ }^{6}\end{array}$ & 7 & 54 & $4 / 30 / 2017$ & 7.46 & 4,010 & $9.4 \%$ & 11 & $8.4 \%$ & $17.0 \%$ & 1,310 & 1,040 & 1,620 & 2,700 & 2,160 & 3,420 \\
\hline 16 & 06927000 & $\begin{array}{l}\text { Maries River at } \\
\text { Westphalia, Missouri }\end{array}$ & 6 & 63 & 4/30/2017 & 21.00 & 27,400 & $7.5 \%$ & 13 & $5.9 \%$ & $12.8 \%$ & 12,800 & 11,400 & 14,300 & 19,800 & 17,600 & 22,400 \\
\hline 17 & 06928000 & $\begin{array}{l}\text { Gasconade River near } \\
\text { Hazelgreen, Missouri }\end{array}$ & 1 & 73 & $4 / 30 / 2017$ & 39.74 & 119,000 & $1.4 \%$ & 73 & $0.2 \%$ & $2.4 \%$ & 25,000 & 21,300 & 29,400 & 48,000 & 41,200 & 56,000 \\
\hline 18 & 06930000 & $\begin{array}{l}\text { Big Piney River near Big } \\
\text { Piney, Missouri }\end{array}$ & 1 & 88 & $4 / 30 / 2017$ & 30.67 & 90,200 & $0.22 \%$ & 453 & $0.2 \%$ & $2.0 \%$ & 13,300 & 11,500 & 15,400 & 25,100 & 21,700 & 29,000 \\
\hline 19 & 06933500 & $\begin{array}{l}\text { Gasconade River at } \\
\text { Jerome, Missouri }\end{array}$ & 1 & 99 & $5 / 1 / 2017$ & 35.06 & 197,000 & $0.47 \%$ & 215 & $0.2 \%$ & $1.8 \%$ & 30,400 & 26,800 & 34,400 & 57,100 & 50,500 & 64,500 \\
\hline 20 & 06934000 & $\begin{array}{l}\text { Gasconade River near } \\
\text { Rich Fountain, } \\
\text { Missouri }\end{array}$ & 1 & 78 & $5 / 2 / 2017$ & 37.46 & 190,000 & $0.54 \%$ & 186 & $0.2 \%$ & $2.3 \%$ & 34,000 & 29,800 & 38,900 & 61,400 & 53,800 & 70,000 \\
\hline 21 & 07010350 & $\begin{array}{l}\text { Meramec River at Cook } \\
\text { Station, Missouri }\end{array}$ & 3 & 26 & $4 / 30 / 2017$ & 16.90 & 26,200 & $5.7 \%$ & 17 & $5.5 \%$ & $16.7 \%$ & 6,750 & 4,980 & 9,150 & 14,500 & 11,100 & 19,000 \\
\hline
\end{tabular}


Table 3. Estimated annual exceedance probability of the 2017 flood peaks and weighted peak streamflow estimates for selected flood quantiles at 59 U.S. Geological Survey streamgages included in this study.-Continued

[ID, identifier; USGS, U.S. Geological Survey; ft, foot; $\mathrm{ft}^{3} / \mathrm{s}$, cubic foot per second; AEP, annual exceedance probability; \%, percent; --, not calculated; stations with peak of record during April-May 2017 flood are shown with rank value of "1" in bold]

\begin{tabular}{|c|c|c|c|c|c|c|c|c|c|c|c|c|c|c|c|c|c|}
\hline \multicolumn{18}{|c|}{$\begin{array}{l}\text { Expected peak streamflows for selected AEP with 95-percent confidence limits } \\
\qquad\left(\mathrm{ft}^{3} / \mathrm{s}\right)\end{array}$} \\
\hline \multicolumn{3}{|c|}{$\begin{array}{l}\text { 10-percent AEP } \\
\text { (10-year recurrence) }\end{array}$} & \multicolumn{3}{|c|}{$\begin{array}{l}\text { 4-percent AEP } \\
\text { (25-year recurrence) }\end{array}$} & \multicolumn{3}{|c|}{$\begin{array}{l}\text { 2-percent AEP } \\
\text { (50-year recurrence) }\end{array}$} & \multicolumn{3}{|c|}{$\begin{array}{l}\text { 1-percent AEP } \\
\text { (100-year recurrence) }\end{array}$} & \multicolumn{3}{|c|}{$\begin{array}{l}\text { 0.5-percent AEP } \\
\text { (200-year recurrence) }\end{array}$} & \multicolumn{3}{|c|}{$\begin{array}{l}\text { 0.2-percent AEP } \\
\text { (500-year recurrence) }\end{array}$} \\
\hline \multirow{2}{*}{ 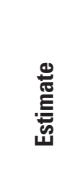 } & \multicolumn{2}{|c|}{$\begin{array}{l}\text { 95\% confidence } \\
\text { limits }^{2}\end{array}$} & \multirow{2}{*}{ 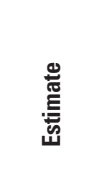 } & \multicolumn{2}{|c|}{$\begin{array}{c}\text { 95\% confidence } \\
\text { limits }^{2}\end{array}$} & \multirow{2}{*}{ 总 } & \multicolumn{2}{|c|}{$\begin{array}{c}\text { 95\% confidence } \\
\text { limits }^{2}\end{array}$} & \multirow{2}{*}{ 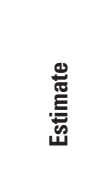 } & \multicolumn{2}{|c|}{$\begin{array}{c}\text { 95\% confidence } \\
\text { limits }^{2}\end{array}$} & \multirow[b]{2}{*}{ Estimate } & \multicolumn{2}{|c|}{$\begin{array}{c}\text { 95\% confidence } \\
\text { limits }^{2}\end{array}$} & \multirow{2}{*}{ 志 } & \multicolumn{2}{|c|}{$\begin{array}{l}\text { 95\% confidence } \\
\text { limits }^{2}\end{array}$} \\
\hline & ¿ై & $\frac{\grave{2}}{\mathrm{O}}$ & & ¿ై & $\frac{\grave{2}}{5}$ & & ఏై & $\frac{\text { 흘 }}{5}$ & & ذై & $\frac{\grave{\Xi}}{\frac{0}{5}}$ & & ఏై & 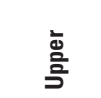 & & ذై & 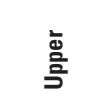 \\
\hline 9,870 & 8,440 & 11,500 & 12,500 & 10,200 & 15,200 & 14,500 & 11,500 & 18,300 & 16,700 & 12,800 & 21,800 & -- & -- & -- & 22,000 & 15,500 & 31,200 \\
\hline 6,610 & 5,480 & 7,980 & 8,940 & 7,050 & 11,300 & 10,900 & 8,260 & 14,400 & 13,100 & 9,500 & 18,000 & -- & -- & -- & 18,900 & 12,500 & 28,600 \\
\hline 8,500 & 7,650 & 9,450 & 9,870 & 8,730 & 11,200 & 10,900 & 9,410 & 12,500 & 11,800 & 10,100 & 13,900 & -- & -- & -- & 14,000 & 11,300 & 17,200 \\
\hline 12,800 & 10,700 & 15,300 & 16,600 & 13,400 & 20,700 & 19,600 & 15,300 & 25,200 & 22,600 & 17,000 & 30,000 & -- & -- & -- & 29,800 & 20,600 & 43,100 \\
\hline 4,920 & 4,020 & 6,010 & 6,800 & 5,310 & 8,700 & 8,320 & 6,250 & 11,100 & 9,910 & 7,140 & 13,800 & -- & -- & -- & 13,900 & 9,110 & 21,300 \\
\hline 5,900 & 5,070 & 6,870 & 7,700 & 6,420 & 9,220 & 9,120 & 7,430 & 11,200 & 10,600 & 8,420 & 13,300 & 12,200 & 9,400 & 15,700 & 14,200 & 10,600 & 19,100 \\
\hline 9,330 & 7,930 & 11,000 & 11,900 & 9,870 & 14,300 & 13,900 & 11,300 & 17,100 & 16,900 & 12,800 & 22,200 & -- & -- & -- & 21,700 & 15,900 & 29,600 \\
\hline 25,300 & 22,200 & 28,900 & 31,200 & 26,600 & 36,500 & 35,400 & 29,600 & 42,300 & 39,600 & 32,300 & 48,500 & 43,700 & 34,800 & 54,900 & 49,200 & 37,900 & 64,000 \\
\hline 10,500 & 9,360 & 12,200 & 12,100 & 10,600 & 14,800 & 13,300 & 11,500 & 16,900 & 14,400 & 12,200 & 19,100 & 15,400 & 12,800 & 21,400 & 16,700 & 13,600 & 24,800 \\
\hline 23,200 & 20,100 & 26,800 & 31,400 & 26,700 & 36,900 & 37,900 & 31,600 & 45,500 & 44,900 & 36,600 & 55,000 & 52,400 & 41,900 & 65,500 & 61,900 & 48,000 & 79,900 \\
\hline 37,500 & 29,400 & 52,000 & 50,700 & 38,600 & 77,600 & 61,000 & 44,900 & 101,000 & 71,700 & 50,600 & 130,000 & 82,800 & 55,900 & 163,000 & 97,900 & 62,200 & 217,000 \\
\hline 23,900 & 20,900 & 27,200 & 28,900 & 24,900 & 33,500 & 32,600 & 27,600 & 38,600 & 36,400 & 30,100 & 43,900 & 40,300 & 32,700 & 49,500 & 45,300 & 35,800 & 57,300 \\
\hline 3,920 & 3,090 & 5,230 & 5,800 & 4,410 & 8,560 & 7,470 & 5,460 & 12,000 & 9,360 & 6,540 & 16,500 & 11,500 & 7,660 & 22,400 & 14,700 & 9,160 & 32,800 \\
\hline 24,900 & 21,600 & 28,600 & 31,500 & 26,700 & 37,100 & 36,700 & 30,400 & 44,300 & 41,900 & 34,000 & 51,800 & 47,400 & 37,600 & 59,700 & 54,900 & 42,000 & 71,700 \\
\hline 65,600 & 56,000 & 76,900 & 89,500 & 74,800 & 107,000 & 108,000 & 87,900 & 132,000 & 126,000 & 100,000 & 158,000 & 145,000 & 113,000 & 186,000 & 170,000 & 128,000 & 226,000 \\
\hline 34,300 & 29,300 & 40,200 & 47,000 & 39,200 & 56,400 & 57,000 & 46,400 & 70,000 & 67,100 & 53,300 & 84,400 & 77,300 & 60,100 & 99,300 & 91,300 & 68,500 & 122,000 \\
\hline 78,700 & 68,700 & 90,100 & 110,000 & 94,000 & 130,000 & 137,000 & 113,000 & 165,000 & 164,000 & 132,000 & 203,000 & 193,000 & 153,000 & 244,000 & 232,000 & 177,000 & 304,000 \\
\hline 82,900 & 71,800 & 95,700 & 114,000 & 96,400 & 134,000 & 139,000 & 115,000 & 167,000 & 165,000 & 133,000 & 203,000 & 192,000 & 152,000 & 242,000 & 229,000 & 175,000 & 299,000 \\
\hline 20,700 & 15,700 & 27,300 & 28,800 & 21,700 & 38,300 & 35,100 & 26,000 & 47,300 & 41,200 & 30,200 & 56,300 & 47,300 & 34,300 & 65,400 & 55,900 & 39,100 & 79,800 \\
\hline
\end{tabular}


Table 3. Estimated annual exceedance probability of the 2017 flood peaks and weighted peak streamflow estimates for selected flood quantiles at 59 U.S. Geological Survey streamgages included in this study.-Continued

[ID, identifier; USGS, U.S. Geological Survey; ft, foot; fts/s, cubic foot per second; AEP, annual exceedance probability; \%, percent; --, not calculated; stations with peak of record during April-May 2017 flood are shown with rank value of "1" in bold]

\begin{tabular}{|c|c|c|c|c|c|c|c|c|c|c|c|c|c|c|c|c|c|}
\hline \multirow{4}{*}{ 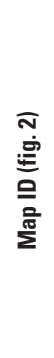 } & \multirow{4}{*}{ 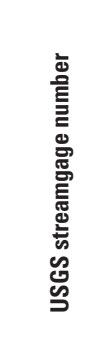 } & \multirow{4}{*}{ 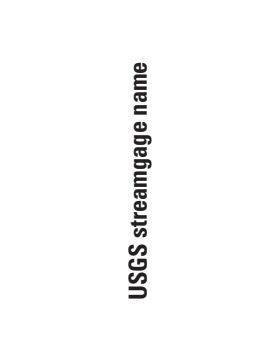 } & \multirow[b]{4}{*}{ 㷚 } & \multirow{4}{*}{ 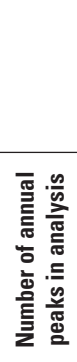 } & \multirow{2}{*}{\multicolumn{3}{|c|}{2017 flood peak }} & \multirow{2}{*}{\multicolumn{4}{|c|}{ AEP for observed 2017 flood }} & \multicolumn{6}{|c|}{$\begin{array}{l}\text { Expected peak streamflows for selected AEP with } \\
95 \text {-percent confidence limits }\left(\mathrm{ft}^{3} / \mathrm{s}\right)\end{array}$} \\
\hline & & & & & & & & & & & & \multirow{2}{*}{\multicolumn{3}{|c|}{$\begin{array}{l}\begin{array}{c}\text { 50-percent AEP } \\
\text { (2-year recurrence) }\end{array} \\
95 \% \text { confidence }^{\text {limits }}{ }^{2}\end{array}$}} & \multirow{2}{*}{\multicolumn{3}{|c|}{$\begin{array}{c}\begin{array}{c}\text { 20-percent AEP } \\
\text { (5-year recurrence) }\end{array} \\
95 \% \text { confidence }^{2} \\
\text { limits }^{2}\end{array}$}} \\
\hline & & & & & \multirow{2}{*}{ 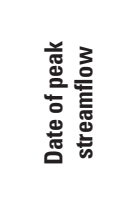 } & \multirow{2}{*}{ 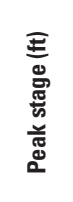 } & \multirow{2}{*}{ 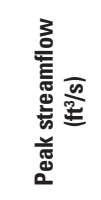 } & \multirow{2}{*}{ 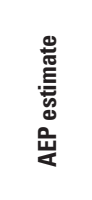 } & \multirow{2}{*}{ 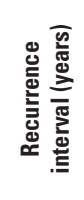 } & \multicolumn{2}{|c|}{$\begin{array}{l}\text { 67\% confidence } \\
\text { interval }\end{array}$} & & & & & & \\
\hline & & & & & & & & & & ఏై & ま흠 & 总 & 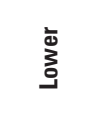 & 흠 & 志 & 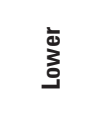 & 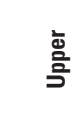 \\
\hline 22 & 07013000 & $\begin{array}{l}\text { Meramec River near } \\
\text { Steelville, Missouri }\end{array}$ & 1 & 102 & $4 / 30 / 2017$ & 28.71 & 62,200 & $2.0 \%$ & 49 & $0.2 \%$ & $1.7 \%$ & 15,400 & 13,600 & 17,400 & 28,100 & 24,700 & 32,100 \\
\hline 23 & 07014500 & $\begin{array}{l}\text { Meramec River near } \\
\text { Sullivan, Missouri }\end{array}$ & 1 & 87 & $4 / 30 / 2017$ & 36.38 & 95,300 & $1.2 \%$ & 84 & $0.2 \%$ & $2.0 \%$ & 21,600 & 19,000 & 24,500 & 38,100 & 33,600 & 43,300 \\
\hline 24 & 07016500 & $\begin{array}{l}\text { Bourbeuse River at } \\
\text { Union, Missouri }\end{array}$ & 5 & 104 & $5 / 2 / 2017$ & 29.38 & 43,800 & $3.2 \%$ & 31 & $2.8 \%$ & $6.7 \%$ & 15,200 & 13,900 & 16,700 & 24,200 & 22,000 & 26,700 \\
\hline 25 & 07018100 & $\begin{array}{l}\text { Big River near } \\
\text { Richwoods, Missouri }\end{array}$ & 1 & 68 & $4 / 30 / 2017$ & 33.54 & 66,900 & $1.8 \%$ & 55 & $0.3 \%$ & $2.6 \%$ & 18,800 & 16,400 & 21,500 & 32,200 & 28,200 & 36,700 \\
\hline 26 & 07018500 & $\begin{array}{l}\text { Big River at Byrnesville, } \\
\text { Missouri }\end{array}$ & 3 & 96 & $5 / 1 / 2017$ & 30.09 & 62,600 & $1.6 \%$ & 62 & $1.5 \%$ & $4.7 \%$ & 17,200 & 15,400 & 19,300 & 29,200 & 26,000 & 32,900 \\
\hline 27 & 07019000 & $\begin{array}{l}\text { Meramec River at Eureka, } \\
\text { Missouri }\end{array}$ & 2 & 100 & $5 / 2 / 2017$ & 46.11 & 169,000 & $1.1 \%$ & 87 & $0.7 \%$ & $3.2 \%$ & 40,800 & 36,700 & 45,400 & 69,100 & 61,800 & 77,200 \\
\hline 28 & 07021000 & $\begin{array}{l}\text { Castor River at Zalma, } \\
\text { Missouri }^{3}\end{array}$ & 3 & 88 & $4 / 30 / 2017$ & 29.00 & 69,700 & $0.93 \%$ & 107 & $1.6 \%$ & $5.1 \%$ & 11,900 & 10,300 & 13,800 & 23,700 & 20,300 & 27,600 \\
\hline 29 & 07035800 & $\begin{array}{l}\text { St. Francis River near } \\
\text { Mill Creek, Missouri }\end{array}$ & 2 & 29 & $4 / 30 / 2017$ & 27.32 & 69,300 & $2.7 \%$ & 37 & $2.5 \%$ & $10.7 \%$ & 23,900 & 19,800 & 28,900 & 39,300 & 32,600 & 47,400 \\
\hline 30 & 07036100 & $\begin{array}{l}\text { St. Fancis River near } \\
\text { Saco, Missouri }\end{array}$ & 2 & 26 & $4 / 30 / 2017$ & 33.42 & 110,000 & $0.50 \%$ & 202 & $2.8 \%$ & $11.9 \%$ & 34,500 & 28,900 & 41,300 & 52,900 & 44,300 & 63,100 \\
\hline 31 & 07037500 & $\begin{array}{l}\text { St. Francis River near } \\
\text { Patterson, Missouri }\end{array}$ & 3 & 96 & $4 / 30 / 2017$ & 37.13 & 126,000 & $0.50 \%$ & 191 & $1.5 \%$ & $4.7 \%$ & 33,800 & 30,700 & 37,400 & 53,300 & 48,000 & 59,200 \\
\hline 32 & 07043500 & $\begin{array}{l}\text { Little River Ditch No. } 1 \\
\text { near Morehouse, } \\
\text { Missouri }\end{array}$ & 10 & 69 & $5 / 1 / 2017$ & 18.99 & 9,500 & $11.5 \%$ & 9 & $10.3 \%$ & $18.3 \%$ & 6,430 & 5,970 & 6,940 & 8,500 & 7,890 & 9,160 \\
\hline 33 & 07050700 & $\begin{array}{l}\text { James River near } \\
\text { Springfield, Missouri }{ }^{3}\end{array}$ & 4 & 63 & $4 / 30 / 2017$ & 20.90 & 38,100 & $3.1 \%$ & 32 & $3.4 \%$ & $9.0 \%$ & 12,500 & 10,800 & 14,400 & 21,300 & 18,400 & 24,600 \\
\hline 34 & 07052100 & $\begin{array}{l}\text { Wilson Creek near } \\
\text { Springfield, Missouri }{ }^{4}\end{array}$ & 6 & 29 & $4 / 29 / 2017$ & 9.15 & 4,220 & $20.1 \%$ & 5 & $13.0 \%$ & $26.9 \%$ & 2,920 & 2,550 & 3,340 & 4,220 & 3,700 & 4,820 \\
\hline 35 & 07052500 & $\begin{array}{l}\text { James River at Galena, } \\
\text { Missouri }\end{array}$ & 2 & 96 & $4 / 30 / 2017$ & 35.97 & 82,800 & $1.5 \%$ & 67 & $0.8 \%$ & $3.3 \%$ & 20,700 & 18,300 & 23,500 & 36,400 & 32,200 & 41,100 \\
\hline 36 & 07055607 & $\begin{array}{l}\text { Crooked Creek at Kelly } \\
\text { Crossing at Yellville, } \\
\text { Arkansas }\end{array}$ & 1 & 33 & $4 / 30 / 2017$ & 31.87 & 95,200 & $0.70 \%$ & 143 & $0.6 \%$ & $5.3 \%$ & 10,100 & 7,760 & 13,200 & 22,900 & 17,400 & 30,200 \\
\hline 37 & 07057500 & $\begin{array}{l}\text { North Fork River near } \\
\text { Tecumseh, Missouri }\end{array}$ & 1 & 73 & $4 / 29 / 2017$ & 41.82 & 189,000 & $<0.20 \%$ & $>500$ & $0.2 \%$ & $2.4 \%$ & 13,200 & 11,200 & 15,600 & 26,800 & 22,400 & 32,000 \\
\hline 38 & 07058000 & $\begin{array}{l}\text { Bryant Creek near } \\
\text { Tecumseh, Missouri }\end{array}$ & 1 & 63 & $4 / 29 / 2017$ & 33.07 & 111,000 & $<0.20 \%$ & $>500$ & $0.3 \%$ & $2.8 \%$ & 12,600 & 10,500 & 15,200 & 25,400 & 21,300 & 30,300 \\
\hline 39 & 07061500 & $\begin{array}{l}\text { Black River near } \\
\text { Annapolis, Missouri }^{5}\end{array}$ & 3 & 55 & $4 / 30 / 2017$ & 23.30 & 71,200 & $4.9 \%$ & 20 & $2.6 \%$ & $8.1 \%$ & 23,100 & 11,800 & 27,200 & 41,300 & 33,100 & 53,200 \\
\hline 40 & 07063000 & $\begin{array}{c}\text { Black River at Poplar } \\
\text { Bluff, Missouri }\end{array}$ & 3 & 70 & $5 / 1 / 2017$ & 21.96 & 29,700 & $37.1 \%$ & 3 & $2.0 \%$ & $6.4 \%$ & 8,040 & 6,940 & 9,340 & 13,500 & 11,500 & 16,400 \\
\hline 41 & 07066000 & $\begin{array}{l}\text { Jacks Fork at Eminence, } \\
\text { Missouri }\end{array}$ & 1 & 96 & $4 / 30 / 2017$ & 27.72 & 106,000 & $0.20 \%$ & 500 & $0.2 \%$ & $1.8 \%$ & 12,600 & 10,700 & 14,800 & 25,700 & 22,000 & 30,100 \\
\hline 42 & 07067000 & $\begin{array}{c}\text { Current River at Van } \\
\text { Buren, Missouri }\end{array}$ & 1 & 106 & $4 / 30 / 2017$ & 37.42 & 179,000 & $0.47 \%$ & 213 & $0.2 \%$ & $1.7 \%$ & 27,800 & 24,300 & 31,700 & 53,400 & 46,600 & 61,200 \\
\hline 43 & 07068000 & $\begin{array}{l}\text { Current River at } \\
\text { Doniphan, Missouri }\end{array}$ & 1 & 101 & $5 / 1 / 2017$ & 33.13 & 183,000 & $0.37 \%$ & 274 & $0.2 \%$ & $1.8 \%$ & 28,300 & 24,500 & 32,700 & 55,300 & 48,100 & 63,700 \\
\hline
\end{tabular}


Table 3. Estimated annual exceedance probability of the 2017 flood peaks and weighted peak streamflow estimates for selected flood quantiles at 59 U.S. Geological Survey streamgages included in this study.-Continued

[ID, identifier; USGS, U.S. Geological Survey; ft, foot; $\mathrm{ft}^{3} / \mathrm{s}$, cubic foot per second; AEP, annual exceedance probability; \%, percent; --, not calculated; stations with peak of record during April-May 2017 flood are shown with rank value of "1" in bold]

\begin{tabular}{|c|c|c|c|c|c|c|c|c|c|c|c|c|c|c|c|c|c|}
\hline \multicolumn{18}{|c|}{$\begin{array}{l}\text { Expected peak streamflows for selected AEP with 95-percent confidence limits } \\
\qquad\left(\mathrm{ft}^{3} / \mathrm{s}\right)\end{array}$} \\
\hline \multicolumn{3}{|c|}{$\begin{array}{l}\text { 10-percent AEP } \\
\text { (10-year recurrence) }\end{array}$} & \multicolumn{3}{|c|}{$\begin{array}{l}\text { 4-percent AEP } \\
\text { (25-year recurrence) }\end{array}$} & \multicolumn{3}{|c|}{$\begin{array}{l}\text { 2-percent AEP } \\
\text { (50-year recurrence) }\end{array}$} & \multicolumn{3}{|c|}{$\begin{array}{l}\text { 1-percent AEP } \\
\text { (100-year recurrence) }\end{array}$} & \multicolumn{3}{|c|}{$\begin{array}{l}\text { 0.5-percent AEP } \\
\text { (200-year recurrence) }\end{array}$} & \multicolumn{3}{|c|}{$\begin{array}{l}\text { 0.2-percent AEP } \\
\text { (500-year recurrence) }\end{array}$} \\
\hline \multirow{2}{*}{ 忍 } & \multicolumn{2}{|c|}{$\begin{array}{l}95 \% \text { confidence } \\
\text { limits }^{2}\end{array}$} & \multirow{2}{*}{ 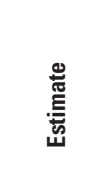 } & \multicolumn{2}{|c|}{$\begin{array}{l}\text { 95\% confidence } \\
\text { limits }^{2}\end{array}$} & \multirow{2}{*}{ 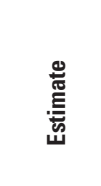 } & \multicolumn{2}{|c|}{$\begin{array}{l}95 \% \text { confidence } \\
\text { limits }^{2}\end{array}$} & \multirow{2}{*}{ 总 } & \multicolumn{2}{|c|}{$\begin{array}{l}95 \% \text { confidence } \\
\text { limits }^{2}\end{array}$} & \multirow[b]{2}{*}{ Estimate } & \multicolumn{2}{|c|}{$\begin{array}{l}\text { 95\% confidence } \\
\text { limits }^{2}\end{array}$} & \multirow{2}{*}{ 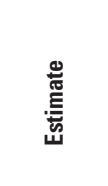 } & \multicolumn{2}{|c|}{$\begin{array}{l}95 \% \text { confidence } \\
\text { limits }^{2}\end{array}$} \\
\hline & ذِّ & 흠 & & 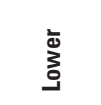 & $\frac{\text { む }}{\frac{2}{3}}$ & & 㐫 & 흠 & & ذِّ & $\frac{\text { む }}{\frac{2}{5}}$ & & ذِّ & $\frac{\text { む }}{\text { 흠 }}$ & & 离 & $\frac{\text { 흠 }}{\frac{2}{5}}$ \\
\hline 38,000 & 32,900 & 43,800 & 51,600 & 43,800 & 60,900 & 62,400 & 51,700 & 75,400 & 73,600 & 59,500 & 91,000 & 85,200 & 67,300 & 108,000 & 101,000 & 76,800 & 132,000 \\
\hline 50,800 & 44,200 & 58,400 & 68,700 & 58,600 & 80,600 & 83,000 & 69,400 & 99,300 & 98,400 & 80,400 & 120,000 & 115,000 & 92,000 & 144,000 & 136,000 & 105,000 & 176,000 \\
\hline 31,100 & 27,700 & 34,900 & 40,800 & 35,400 & 46,900 & 48,600 & 41,300 & 57,100 & 56,900 & 47,300 & 68,400 & 65,800 & 53,500 & 80,900 & 77,900 & 61,300 & 99,000 \\
\hline 41,900 & 36,400 & 48,200 & 54,900 & 46,700 & 64,600 & 65,000 & 54,200 & 77,900 & 75,200 & 61,400 & 92,200 & 85,800 & 68,600 & 107,000 & 99,800 & 77,100 & 129,000 \\
\hline 38,000 & 33,500 & 43,100 & 49,800 & 42,900 & 57,900 & 59,100 & 49,700 & 70,300 & 68,600 & 56,400 & 83,400 & 78,600 & 63,200 & 97,700 & 91,700 & 71,400 & 118,000 \\
\hline 90,500 & 80,200 & 102,000 & 121,000 & 105,000 & 140,000 & 146,000 & 124,000 & 173,000 & 173,000 & 143,000 & 210,000 & 202,000 & 163,000 & 251,000 & 240,000 & 188,000 & 308,000 \\
\hline 33,400 & 28,200 & 39,500 & 47,000 & 38,600 & 57,300 & 57,700 & 46,200 & 72,200 & 68,400 & 53,400 & 87,600 & 78,900 & 60,300 & 103,000 & 94,100 & 69,300 & 128,000 \\
\hline 49,700 & 40,600 & 60,900 & 62,900 & 50,300 & 78,600 & 73,100 & 57,200 & 93,300 & 83,100 & 63,800 & 108,000 & 93,300 & 70,400 & 124,000 & 108,000 & 78,500 & 148,000 \\
\hline 64,500 & 53,300 & 78,100 & 78,200 & 63,300 & 96,700 & 88,800 & 70,300 & 112,000 & 99,200 & 77,100 & 128,000 & 110,000 & 83,900 & 144,000 & 125,000 & 92,400 & 169,000 \\
\hline 67,100 & 59,700 & 75,300 & 84,900 & 73,700 & 97,800 & 98,700 & 83,900 & 116,000 & 113,000 & 93,600 & 135,000 & 127,000 & 103,000 & 156,000 & 146,000 & 115,000 & 186,000 \\
\hline 27,500 & 23,500 & 32,100 & 35,500 & 29,900 & 42,100 & 41,600 & 34,400 & 50,200 & 47,600 & 38,700 & 58,600 & 53,700 & 42,900 & 67,300 & 62,000 & 48,000 & 80,100 \\
\hline 5,180 & 4,490 & 5,980 & 6,480 & 5,510 & 7,620 & 7,640 & 6,370 & 9,160 & 8,800 & 7,200 & 10,800 & -- & -- & -- & 11,800 & 9,210 & 15,100 \\
\hline 48,100 & 42,000 & 55,000 & 64,100 & 54,700 & 75,200 & 76,600 & 63,900 & 91,900 & 89,600 & 73,100 & 110,000 & 103,000 & 82,300 & 129,000 & 121,000 & 93,200 & 157,000 \\
\hline 34,200 & 25,600 & 45,800 & 51,500 & 38,000 & 69,800 & 66,000 & 47,900 & 91,100 & 81,600 & 58,400 & 114,000 & -- & -- & -- & 123,000 & 83,900 & 180,000 \\
\hline 38,500 & 31,500 & 47,100 & 55,700 & 44,200 & 70,100 & 69,300 & 53,600 & 89,600 & 83,000 & 62,800 & 110,000 & 96,900 & 71,900 & 131,000 & 116,000 & 83,200 & 163,000 \\
\hline 35,700 & 29,600 & 43,200 & 50,400 & 40,700 & 62,300 & 61,700 & 48,800 & 78,100 & 73,300 & 56,600 & 94,900 & 85,000 & 64,400 & 112,000 & 101,000 & 73,600 & 138,000 \\
\hline 55,200 & 44,900 & 79,000 & 74,500 & 57,000 & 136,000 & 89,900 & 65,900 & 212,000 & 106,000 & 74,700 & 311,000 & 123,000 & 83,200 & 422,000 & 147,000 & 94,400 & 613,000 \\
\hline 17,800 & 14,900 & 23,100 & 24,300 & 19,600 & 34,900 & 29,900 & 23,200 & 46,800 & 36,100 & 27,000 & 62,100 & 43,000 & 31,000 & 81,600 & 53,400 & 36,400 & 116,000 \\
\hline 35,900 & 30,300 & 42,500 & 49,400 & 40,900 & 59,600 & 59,700 & 48,400 & 73,500 & 69,700 & 55,400 & 87,700 & 79,400 & 61,800 & 102,000 & 93,000 & 69,900 & 124,000 \\
\hline 73,900 & 63,700 & 85,600 & 103,000 & 86,800 & 123,000 & 127,000 & 104,000 & 154,000 & 151,000 & 121,000 & 189,000 & 176,000 & 138,000 & 225,000 & 209,000 & 158,000 & 277,000 \\
\hline 76,000 & 65,300 & 88,400 & 104,000 & 87,900 & 124,000 & 126,000 & 104,000 & 153,000 & 148,000 & 119,000 & 183,000 & 170,000 & 134,000 & 216,000 & 200,000 & 152,000 & 262,000 \\
\hline
\end{tabular}


Table 3. Estimated annual exceedance probability of the 2017 flood peaks and weighted peak streamflow estimates for selected flood quantiles at 59 U.S. Geological Survey streamgages included in this study.-Continued

[ID, identifier; USGS, U.S. Geological Survey; ft, foot; $\mathrm{ft}$ /s, cubic foot per second; AEP, annual exceedance probability; \%, percent; --, not calculated; stations with peak of record during April-May 2017 flood are shown with rank value of "1" in bold]

\begin{tabular}{|c|c|c|c|c|c|c|c|c|c|c|c|c|c|c|c|c|c|}
\hline \multirow{4}{*}{ 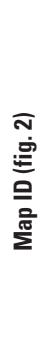 } & \multirow{4}{*}{ 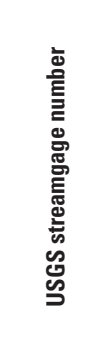 } & \multirow{4}{*}{ 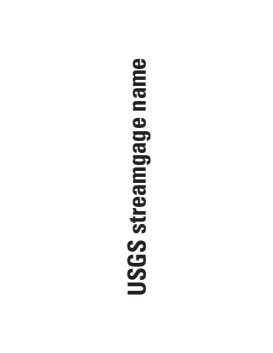 } & \multirow{2}{*}{\multicolumn{5}{|c|}{2017 flood peak }} & \multirow{2}{*}{\multicolumn{4}{|c|}{ AEP for observed 2017 flood }} & \multicolumn{6}{|c|}{$\begin{array}{c}\text { Expected peak streamflows for selected AEP with } \\
95 \text {-percent confidence limits }\left(\mathrm{ft}^{3} / \mathrm{s}\right)\end{array}$} \\
\hline & & & & & & & & & & & & $\begin{array}{r}50- \\
(2-y e\end{array}$ & $\begin{array}{l}\text { percent } A \\
\text { ar recurre }\end{array}$ & $\begin{array}{l}\text { AEP } \\
\text { ence) }\end{array}$ & $\begin{array}{r}20 \\
(5-y e\end{array}$ & percent $f$ & $\begin{array}{l}\text { IEP } \\
\text { ence) }\end{array}$ \\
\hline & & & \multirow[b]{2}{*}{ 羔 } & \multirow{2}{*}{ 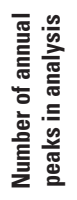 } & \multirow{2}{*}{ 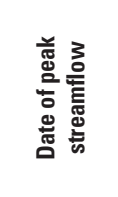 } & \multirow{2}{*}{ 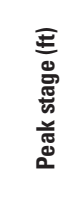 } & \multirow{2}{*}{ 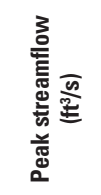 } & \multirow{2}{*}{ 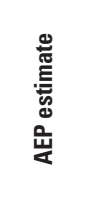 } & \multirow{2}{*}{ 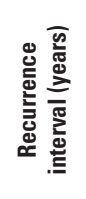 } & \multicolumn{2}{|c|}{$\begin{array}{l}\text { 67\% confidence } \\
\text { interval }^{1}\end{array}$} & \multirow{2}{*}{ 总 } & \multicolumn{2}{|c|}{$\begin{array}{l}\text { 95\% confidence } \\
\text { limits }^{2}\end{array}$} & \multirow{2}{*}{ 志 } & \multicolumn{2}{|c|}{$\begin{array}{l}95 \% \text { confidence } \\
\text { limits }^{2}\end{array}$} \\
\hline & & & & & & & & & & 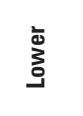 & 흠 & & $\sum_{0}^{2}$ & 흠 & & 离 & むँ \\
\hline 44 & 07069000 & $\begin{array}{l}\text { Black River at } \\
\text { Pocahontas, Arkansas }{ }^{3}\end{array}$ & 1 & 77 & $5 / 2 / 2017$ & 28.95 & 105,000 & $1.0 \%$ & 96 & $0.2 \%$ & $2.3 \%$ & 23,550 & 14,510 & 27,240 & 41,970 & 35,650 & 50,660 \\
\hline 45 & 07071500 & $\begin{array}{l}\text { Eleven Point River near } \\
\text { Bardley, Missouri }\end{array}$ & 1 & 97 & $4 / 30 / 2017$ & 28.66 & 124,000 & $<0.20 \%$ & $>500$ & $0.2 \%$ & $1.8 \%$ & 9,930 & 8,430 & 11,700 & 21,900 & 18,500 & 25,800 \\
\hline 46 & 07072000 & $\begin{array}{l}\text { Eleven Point River near } \\
\text { Ravenden Springs, } \\
\text { Arkansas }\end{array}$ & 1 & 86 & $5 / 1 / 2017$ & 27.90 & 137,000 & $<0.20 \%$ & $>500$ & $0.2 \%$ & $2.1 \%$ & 12,700 & 11,000 & 14,700 & 25,500 & 21,800 & 29,800 \\
\hline 47 & 07074420 & $\begin{array}{l}\text { Black River at Elgin } \\
\text { Ferry, Arkansas }\end{array}$ & 2 & 27 & $5 / 4 / 2017$ & 33.99 & 173,000 & $0.83 \%$ & 120 & $2.7 \%$ & $11.5 \%$ & 41,590 & 33,000 & 51,180 & 67,950 & 54,720 & 88,590 \\
\hline 48 & 07076750 & $\begin{array}{l}\text { White River at } \\
\text { Georgetown, } \\
\text { Arkansas5 }\end{array}$ & 1 & 38 & $5 / 8 / 2017$ & 31.50 & 200,000 & $1.1 \%$ & 90 & $0.5 \%$ & $4.6 \%$ & 69,300 & 59,400 & 81,000 & 102,000 & 87,000 & 124,000 \\
\hline 49 & 07077000 & $\begin{array}{l}\text { White River at DeValls } \\
\text { Bluff, Arkansas }\end{array}$ & 2 & 47 & $5 / 10 / 2017$ & 31.31 & 187,000 & $0.88 \%$ & 114 & $2.1 \%$ & $6.7 \%$ & 71,900 & 63,600 & 80,800 & 101,000 & 89,200 & 115,000 \\
\hline 50 & 07077555 & $\begin{array}{l}\text { Cache River near Cotton } \\
\text { Plant, Arkansas }\end{array}$ & 1 & 31 & $5 / 5 / 2017$ & 20.25 & 10,100 & $9.2 \%$ & 11 & $0.6 \%$ & $5.6 \%$ & 6,790 & 6,080 & 7,590 & 8,750 & 7,930 & 9,660 \\
\hline 51 & 07185765 & $\begin{array}{l}\text { Spring River at Carthage, } \\
\text { Missouri }\end{array}$ & 2 & 30 & $4 / 29 / 2017$ & 18.44 & 30,400 & $8.2 \%$ & 12 & $2.5 \%$ & $10.4 \%$ & 9,430 & 7,380 & 12,000 & 19,200 & 15,400 & 24,000 \\
\hline 52 & 07186000 & $\begin{array}{l}\text { Spring River near Waco, } \\
\text { Missouri }\end{array}$ & 8 & 95 & $4 / 30 / 2017$ & 28.14 & 55,800 & $8.2 \%$ & 12 & $5.6 \%$ & $11.0 \%$ & 20,000 & 17,600 & 22,800 & 37,100 & 32,500 & 42,300 \\
\hline 53 & 07187000 & $\begin{array}{l}\text { Shoal Creek above Joplin, } \\
\text { Missouri }\end{array}$ & 4 & 94 & $4 / 29 / 2017$ & 22.96 & 52,900 & $2.8 \%$ & 36 & $2.3 \%$ & $6.1 \%$ & 7,700 & 6,580 & 9,000 & 16,500 & 13,900 & 19,500 \\
\hline 54 & 07189000 & $\begin{array}{l}\text { Elk River near Tiff City, } \\
\text { Missouri }^{3}\end{array}$ & 2 & 78 & $4 / 29 / 2017$ & 27.39 & 107,000 & $1.4 \%$ & 70 & $0.9 \%$ & $4.1 \%$ & 22,200 & 18,700 & 26,400 & 43,400 & 37,000 & 51,000 \\
\hline 55 & 07191220 & $\begin{array}{l}\text { Spavinaw Creek near } \\
\text { Sycamore, Oklahoma }\end{array}$ & 2 & 58 & $4 / 29 / 2017$ & 16.94 & 19,900 & $6.5 \%$ & 15 & $1.3 \%$ & $5.5 \%$ & 4,270 & 3,220 & 5,660 & 10,100 & 8,090 & 12,500 \\
\hline 56 & 07195500 & $\begin{array}{l}\text { Illinois River near Watts, } \\
\text { Oklahoma }^{3}\end{array}$ & 1 & 62 & $4 / 30 / 2017$ & 30.12 & 128,000 & $0.31 \%$ & 325 & $0.3 \%$ & $2.8 \%$ & 19,600 & 16,900 & 22,900 & 35,700 & 30,200 & 42,300 \\
\hline 57 & 07196000 & $\begin{array}{l}\text { Flint Creek near Kansas, } \\
\text { Oklahoma }^{3}\end{array}$ & 3 & 58 & $4 / 29 / 2017$ & 18.31 & 19,400 & $8.5 \%$ & 12 & $2.4 \%$ & $7.7 \%$ & 4,170 & 3,230 & 5,370 & 10,800 & 8,450 & 13,800 \\
\hline 58 & 07261000 & $\begin{array}{l}\text { Cadron Creek near Guy, } \\
\text { Arkansas }\end{array}$ & 3 & 61 & $4 / 30 / 2017$ & 23.57 & 18,000 & $7.6 \%$ & 13 & $2.3 \%$ & $7.3 \%$ & 8,520 & 7,570 & 9,590 & 13,200 & 11,800 & 14,900 \\
\hline 59 & 07359610 & $\begin{array}{l}\text { Caddo River near Caddo } \\
\text { Gap, Arkansas }\end{array}$ & 3 & 29 & $4 / 30 / 2017$ & 23.32 & 35,800 & $13.6 \%$ & 7 & $4.9 \%$ & $15.0 \%$ & 19,400 & 16,300 & 23,000 & 30,900 & 25,800 & 37,000 \\
\hline
\end{tabular}

${ }^{1} 66.7 \%$ confidence intervals for observed AEP are determined nonparametrically. In some instances, the nonparametric results place bounds outside the estimate, making these confidence intervals nonsensical.

${ }^{2} 95 \%$ confidence limits or $90 \%$ confidence intervals (both imply $5 \%$ tails).

${ }^{3}$ Streamflow affected to unknown degree by regulation or diversion.

${ }^{4}$ Streamflow affected by urbanization.

${ }^{5}$ Streamflow affected by regulation or diversion. Flood frequency analysis was conducted using only regulated period of record and at-site estimates of peak streamflows without weighting with rural regression equation estimates.

${ }^{6}$ Site is a spring. Expected peak streamflows were determined using only at-site estimates of peak streamflows without weighting with rural regression equation estimates. 
Table 3. Estimated annual exceedance probability of the 2017 flood peaks and weighted peak streamflow estimates for selected flood quantiles at 59 U.S. Geological Survey streamgages included in this study.-Continued

[ID, identifier; USGS, U.S. Geological Survey; $\mathrm{ft}$, foot; $\mathrm{ft}^{3} / \mathrm{s}$, cubic foot per second; AEP, annual exceedance probability; \%, percent; --, not calculated; stations with peak of record during April-May 2017 flood are shown with rank value of "1" in bold]

\begin{tabular}{|c|c|c|c|c|c|c|c|c|c|c|c|c|c|c|c|c|c|}
\hline \multicolumn{18}{|c|}{$\begin{array}{l}\text { Expected peak streamflows for selected AEP with 95-percent confidence limits } \\
\qquad\left(\mathrm{ft}^{3} / \mathrm{s}\right)\end{array}$} \\
\hline \multicolumn{3}{|c|}{$\begin{array}{l}\text { 10-percent AEP } \\
\text { (10-year recurrence) }\end{array}$} & \multicolumn{3}{|c|}{$\begin{array}{l}\text { 4-percent AEP } \\
\text { (25-year recurrence) }\end{array}$} & \multicolumn{3}{|c|}{$\begin{array}{l}\text { 2-percent AEP } \\
\text { (50-year recurrence) }\end{array}$} & \multicolumn{3}{|c|}{$\begin{array}{l}\text { 1-percent AEP } \\
\text { (100-year recurrence) }\end{array}$} & \multicolumn{3}{|c|}{$\begin{array}{l}\text { 0.5-percent AEP } \\
\text { (200-year recurrence) }\end{array}$} & \multicolumn{3}{|c|}{$\begin{array}{l}\text { 0.2-percent AEP } \\
\text { (500-year recurrence) }\end{array}$} \\
\hline \multirow{2}{*}{ 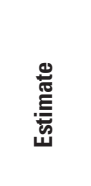 } & \multicolumn{2}{|c|}{$\begin{array}{l}\text { 95\% confidence } \\
\text { limits }^{2}\end{array}$} & \multirow{2}{*}{ 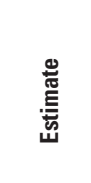 } & \multicolumn{2}{|c|}{$\begin{array}{c}\text { 95\% confidence } \\
\text { limits }^{2}\end{array}$} & \multirow{2}{*}{ 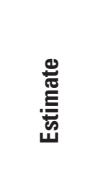 } & \multicolumn{2}{|c|}{$\begin{array}{l}\text { 95\% confidence } \\
\text { limits }^{2}\end{array}$} & \multirow{2}{*}{$\begin{array}{l}\text { 芯 } \\
\text { 䍘 }\end{array}$} & \multicolumn{2}{|c|}{$\begin{array}{l}\text { 95\% confidence } \\
\text { limits }^{2}\end{array}$} & \multirow[b]{2}{*}{ Estimate } & \multicolumn{2}{|c|}{$\begin{array}{l}\text { 95\% confidence } \\
\text { limits }^{2}\end{array}$} & \multirow{2}{*}{ 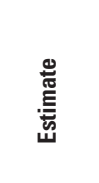 } & \multicolumn{2}{|c|}{$\begin{array}{l}\text { 95\% confidence } \\
\text { limits }^{2}\end{array}$} \\
\hline & ऐo & 흠 & & לूँ & むั & & 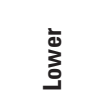 & むo & & 㐫 & 送 & & 㐫 & 흠 & & 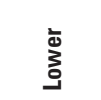 & $\begin{array}{l}\text { む。 } \\
\text { 음 }\end{array}$ \\
\hline 55,890 & 46,590 & 71,790 & 74,960 & 60,050 & 108,800 & 90,050 & 70,120 & 144,100 & 105,700 & 80,070 & 185,800 & 122,100 & 89,880 & 233,700 & 144,700 & 102,600 & 306,000 \\
\hline 32,300 & 27,000 & 38,700 & 48,200 & 39,400 & 59,100 & 61,100 & 48,800 & 76,500 & 74,700 & 58,300 & 95,700 & 89,000 & 68,000 & 116,000 & 107,000 & 79,200 & 146,000 \\
\hline 37,300 & 31,100 & 44,700 & 56,600 & 45,700 & 70,200 & 72,800 & 57,300 & 92,600 & 90,300 & 69,300 & 118,000 & 108,000 & 81,500 & 144,000 & 134,000 & 96,800 & 184,000 \\
\hline 88,090 & 69,730 & 123,700 & 116,400 & 89,000 & 184,100 & 139,600 & 103,300 & 243,500 & 164,400 & 117,400 & 317,700 & 191,200 & 131,400 & 410,300 & 229,700 & 149,700 & 568,300 \\
\hline 125,000 & 105,000 & 160,000 & 155,000 & 127,000 & 216,000 & 179,000 & 142,000 & 266,000 & 203,000 & 158,000 & 325,000 & 228,000 & 172,000 & 394,000 & 262,500 & 190,000 & 502,000 \\
\hline 120,000 & 106,000 & 141,000 & 145,000 & 125,000 & 179,000 & 164,000 & 138,000 & 212,000 & 183,000 & 151,000 & 248,000 & 202,000 & 163,000 & 289,000 & 227,000 & 178,000 & 350,000 \\
\hline 9,920 & 8,820 & 11,200 & 11,300 & 9,730 & 13,100 & 12,200 & 10,300 & 14,500 & 13,100 & 10,800 & 16,000 & -- & -- & -- & 15,100 & 11,800 & 19,400 \\
\hline 27,300 & 21,800 & 34,300 & 39,200 & 30,700 & 50,200 & 48,500 & 37,200 & 63,300 & 58,100 & 43,700 & 77,300 & 68,100 & 50,300 & 92,200 & 80,800 & 57,600 & 113,000 \\
\hline 50,500 & 43,600 & 58,500 & 69,900 & 58,900 & 83,000 & 85,600 & 70,400 & 104,000 & 102,000 & 82,100 & 127,000 & 120,000 & 94,300 & 152,000 & 143,000 & 108,000 & 188,000 \\
\hline 59,600 & 49,600 & 71,500 & 81,200 & 65,900 & 100,000 & 98,000 & 77,900 & 123,000 & 114,000 & 89,200 & 147,000 & 132,000 & 101,000 & 172,000 & 154,000 & 114,000 & 208,000 \\
\hline 15,400 & 12,000 & 19,800 & 24,000 & 17,600 & 32,800 & 32,100 & 22,800 & 45,200 & 41,300 & 28,300 & 60,300 & -- & -- & -- & 67,100 & 42,000 & 107,000 \\
\hline 48,600 & 40,100 & 58,900 & 67,000 & 52,800 & 85,100 & 81,300 & 61,700 & 107,000 & 96,200 & 70,200 & 132,000 & -- & -- & -- & 134,000 & 88,100 & 203,000 \\
\hline 17,200 & 13,300 & 22,300 & 27,700 & 20,300 & 37,800 & 37,100 & 26,300 & 52,300 & 48,000 & 32,700 & 70,400 & -- & -- & -- & 79,200 & 48,400 & 130,000 \\
\hline 16,400 & 14,500 & 18,700 & 20,600 & 17,600 & 24,000 & 23,700 & 19,800 & 28,400 & 26,900 & 21,900 & 33,000 & -- & -- & -- & 34,300 & 26,300 & 44,900 \\
\hline 38,900 & 31,700 & 47,800 & 49,400 & 38,800 & 63,000 & 57,300 & 43,600 & 75,200 & 65,400 & 48,200 & 88,800 & -- & -- & -- & 85,000 & 58,100 & 125,000 \\
\hline
\end{tabular}




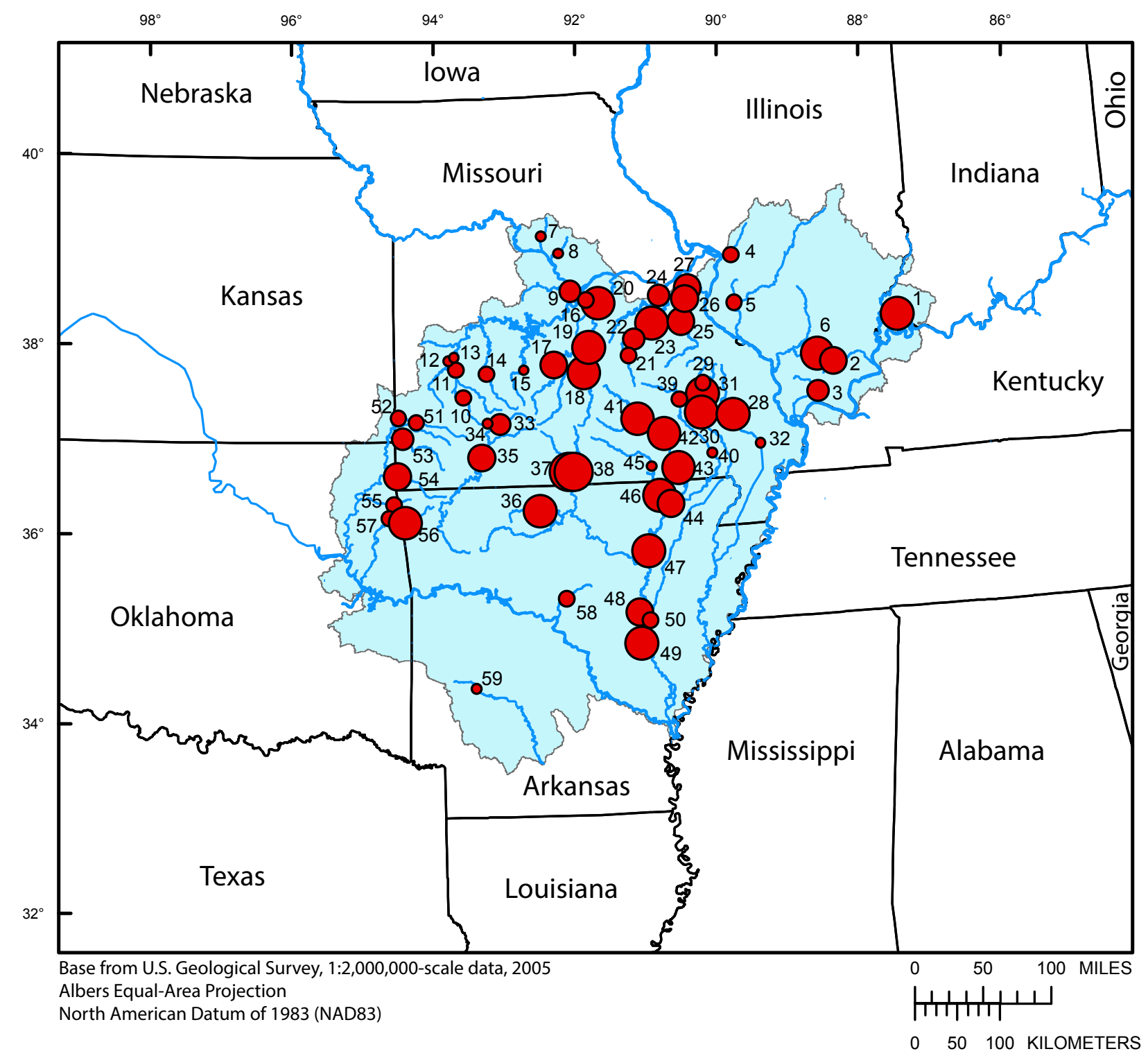

\section{EXPLANATION}

Flood annual exceedance probability (AEP) in percent-- Number is map identifier (table 3)

\section{Mississippi}

- Greater than 10

- 4.1 to 10

( 2.1 to 4.0

1.1 to 2.0

0.21 to 1.0

Less than 0.2

Figure 10. Spatial distribution of the magnitude of annual exceedance probabilities of peak streamflows at 59 U.S. Geological Survey streamgages for the April-May 2017 flood. 

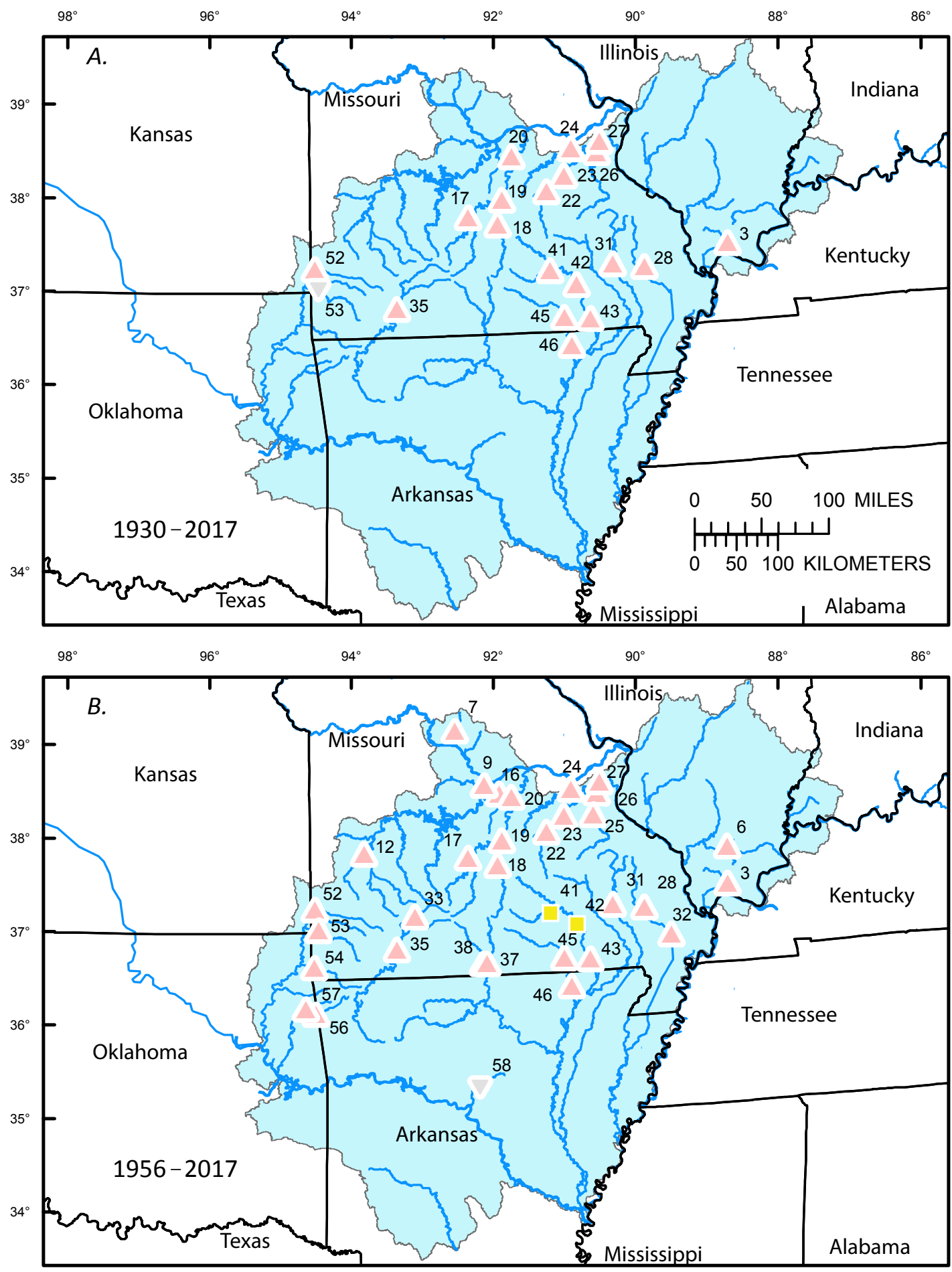

Base from U.S. Geological Survey, 1:2,000,000-scale data, 2005 Albers Equal-Area Projection North American Datum of 1983 (NAD83)

EXPLANATION

Study area

Percent change of the median annual peak streamflow per year and map ID (see table 1) Not all ranges are represented on map

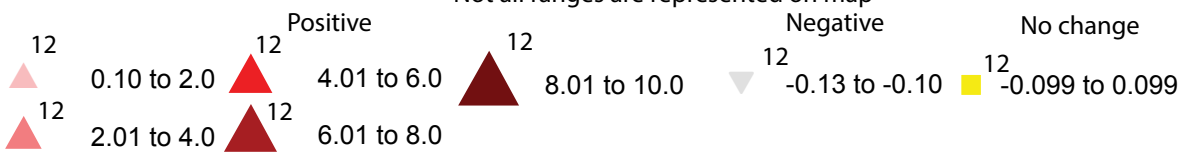

Figure 11. Percentage changes in median annual peak streamflow values for selected U.S. Geological Survey streamgages for $A, 1930-2017 ; B, 1956-2017 ; C, 1975-2017$; and $D, 1989-2017$. 

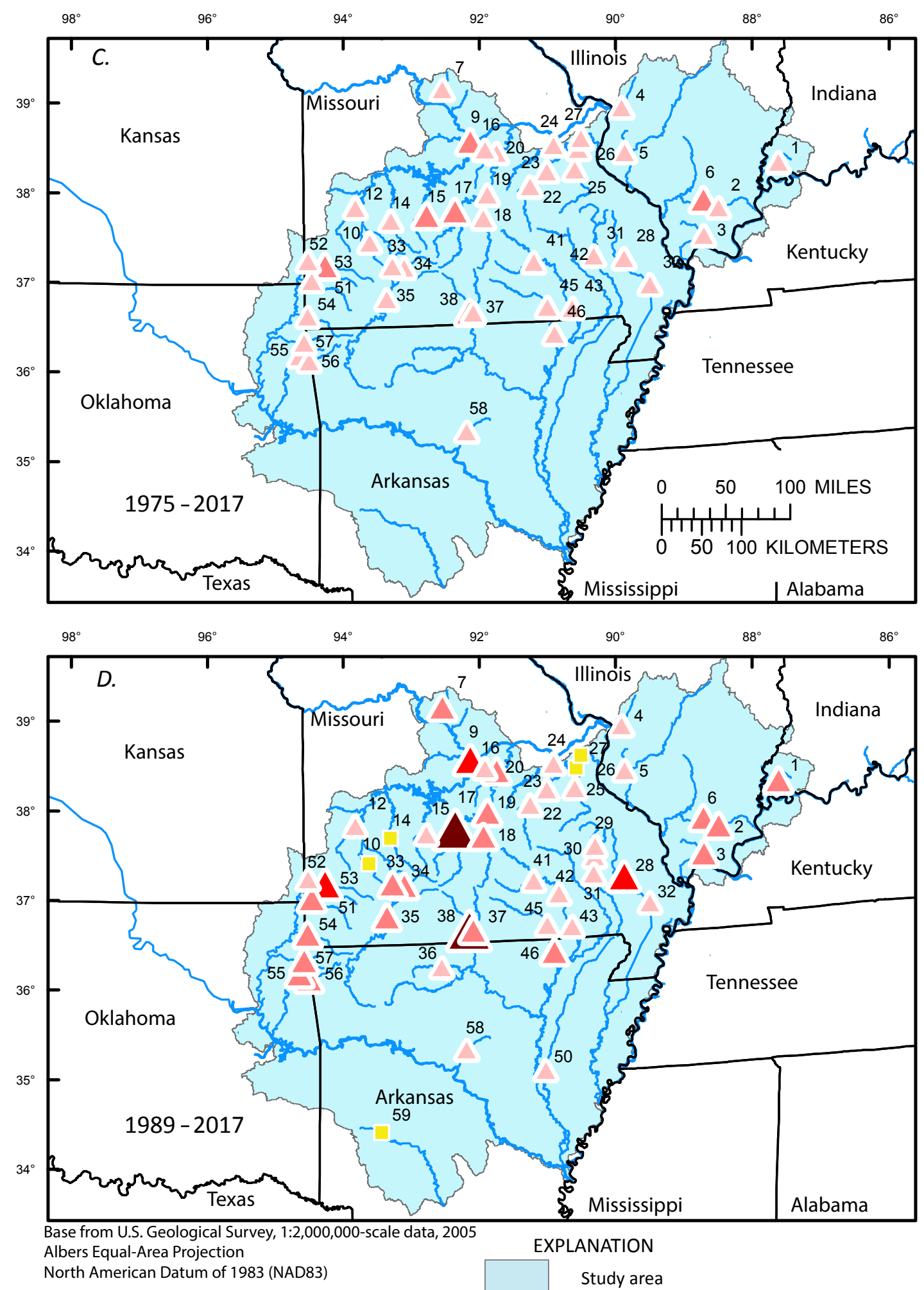

Percent change of the median annual peak streamflow per year and map ID (see table 1)

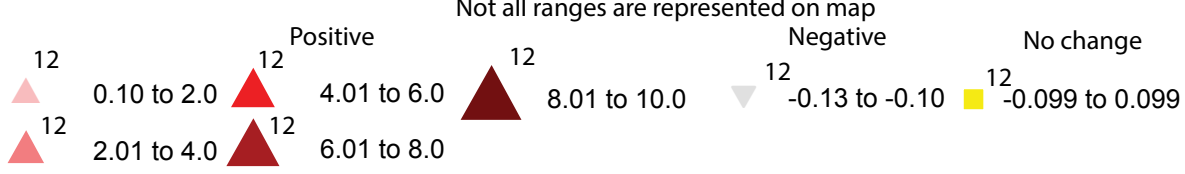

Figure 11. Percentage changes in median annual peak streamflow values for selected U.S. Geological Survey streamgages for $A, 1930-2017 ; B, 1956-2017 ; C, 1975-2017$; and $D, 1989-2017$.- Continued 

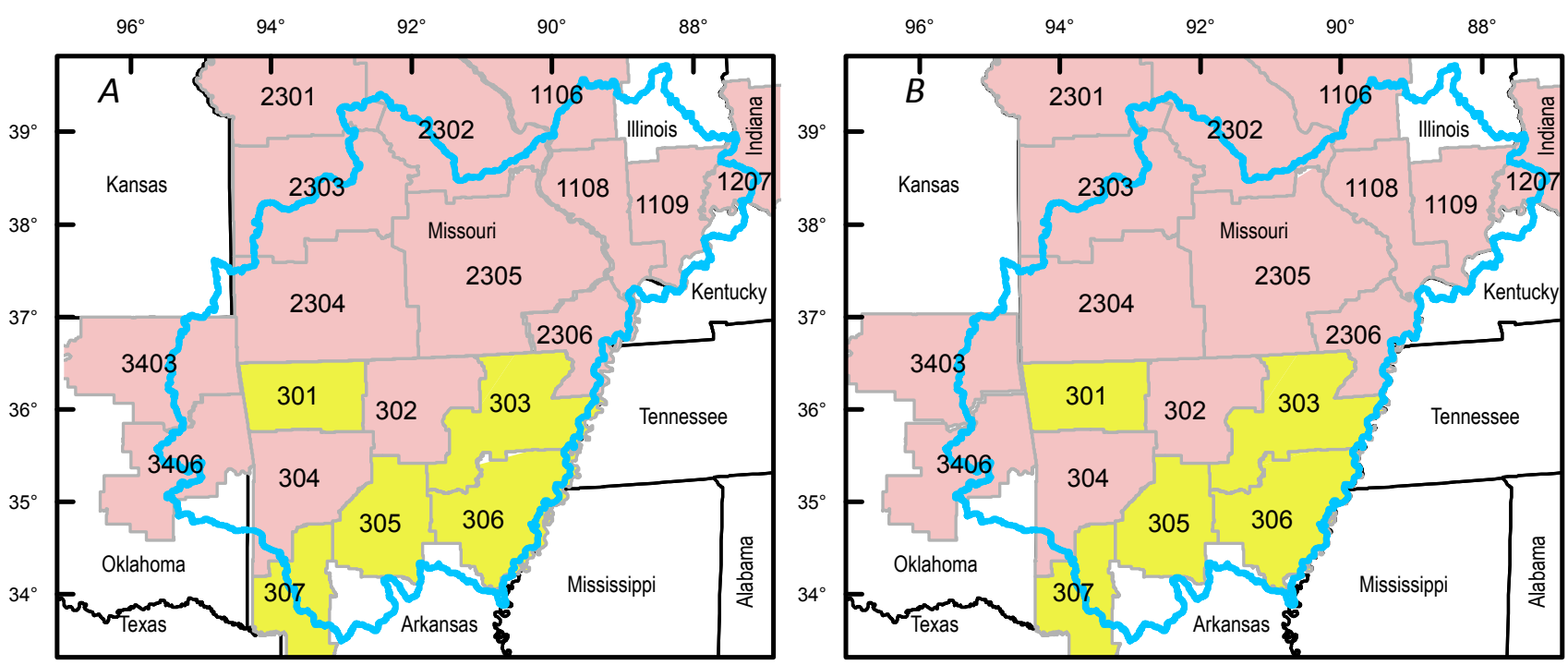

1930-2016

1956-2016
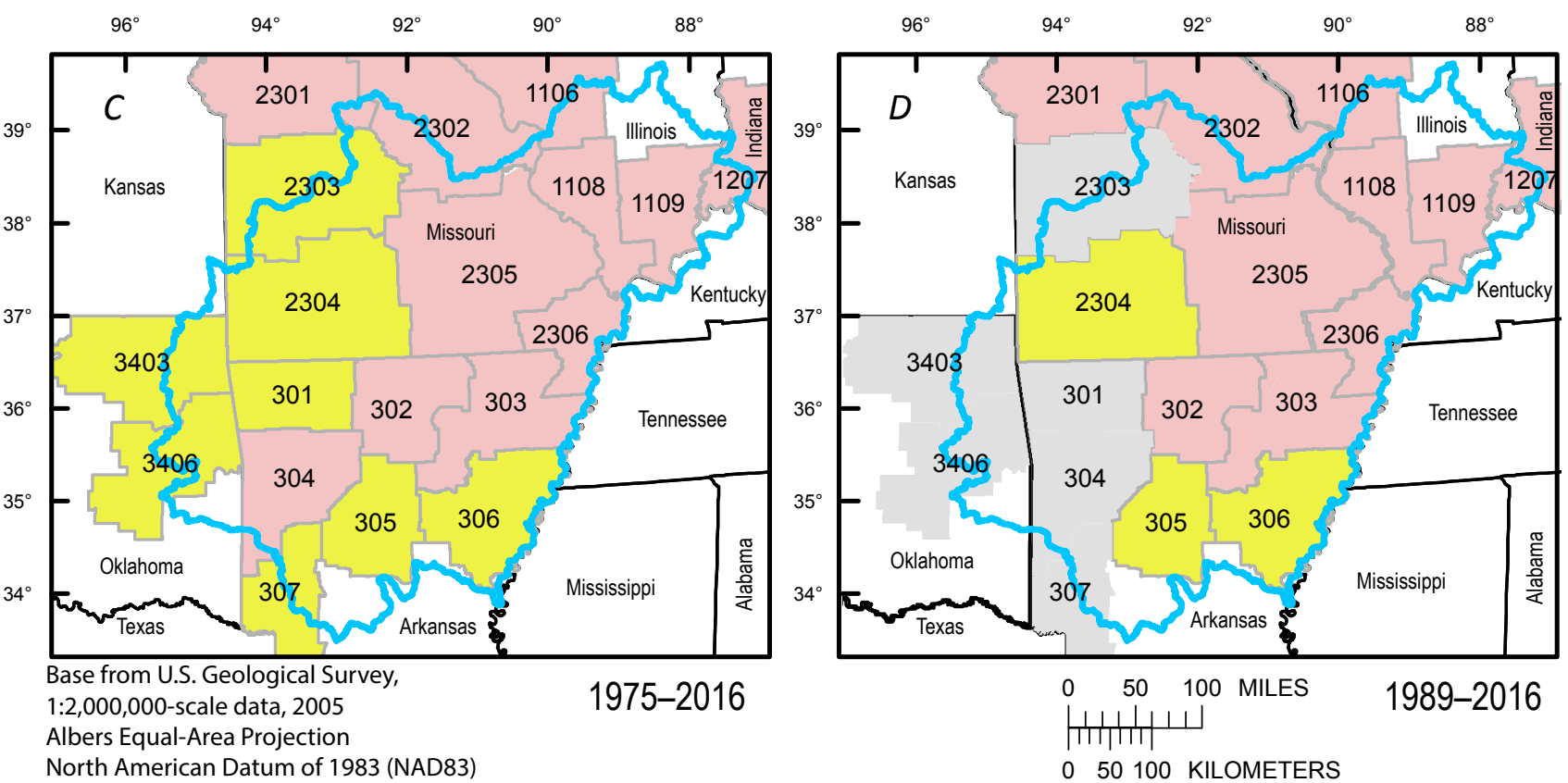

EXPLANATION

$\square$ Flood study area

Climate division and identifier

Percent change of the median annual precipitation, per year

301 Positive change, 0.1 to 0.62

301 No change, -0.099 to +0.099

301 Negative change -0.1 to -0.9

Figure 12. Percentage change in the median annual precipitation by climate division within the study area for $A, 1930-2016$; B, 1956-2016; C, 1975-2016; and D, 1989-2016. 

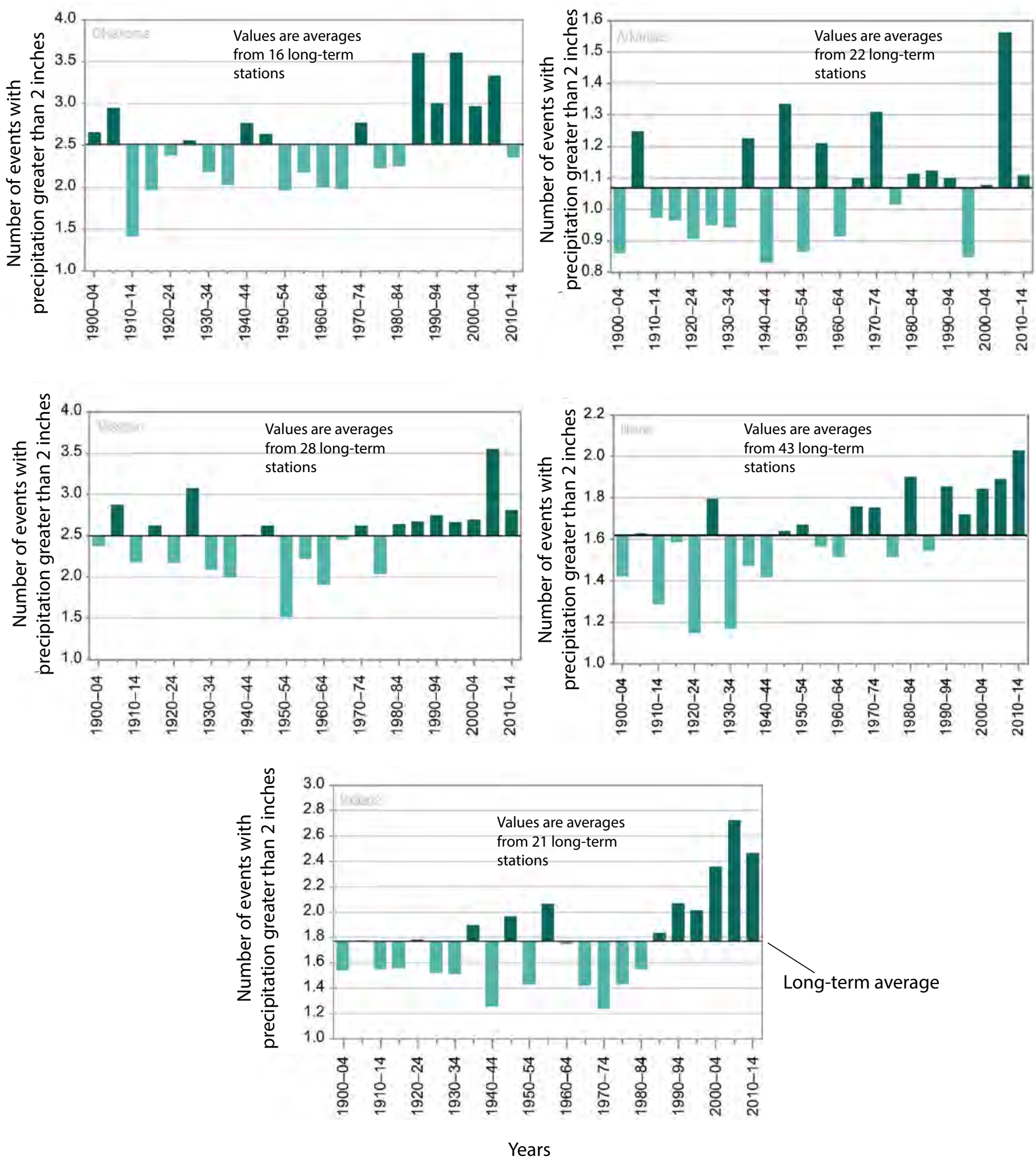

Figure 13. Change in frequency of daily high intensity (greater than 2-3 in.) precipitation from the long-term (1900-2014) average, by state. 


\section{Summary}

Excessive rainfall resulted in flooding on numerous rivers throughout the southern Midwestern United States in late April and early May of 2017. Tropical moisture lifted over a stalled frontal system caused heavy rains from Texas to Ohio between April 28 and May 10, resulting in extensive flooding from eastern Oklahoma to southern Indiana including parts of Missouri, Arkansas, and Illinois. The heaviest rainfall amounts during April 28-30 occurred over extreme northeast Oklahoma and northern Arkansas, across the southern half of Missouri, southern Illinois, and southern Indiana, and included totals of 6 to 10 inches with some isolated higher amounts.

Peak-of-record streamflows were set at 21 U.S. Geological Survey streamgages in the southern Midwest during the resulting April May 2017 flooding. Each of the five states included in the study area had at least one streamgage with a peak of record during the flood. The annual exceedance probability (AEP) estimates for the April May 2017 flood peak streamflows indicate that peaks at 5 USGS streamgages had an AEP of 0.2 percent or less, and peak streamflows at 15 USGS streamgages had an AEP in the range from greater than 0.2 to 1 percent.

Examination of the magnitude of the temporal changes in median annual peak streamflows indicated positive increases, in general, throughout the study area for each of the 1930-2017, 1956-2017, 1975-2017, and 1989-2017 analysis periods. The median increase in peak streamflows was greatest in the 1975-2017 and 1989-2017 periods with maximum increases of 8-10 percent per year. No stations in either the 1975-2017 or 1989-2017 analysis period had median negative changes in peak streamflows.

A primary driver of change in peak streamflows is precipitation, but the changes in annual precipitation provided little explanation for the substantial increase in the magnitude of streamflow peaks in the 1989-2017 analysis period. The increase in the magnitude of the positive changes in annual peak streamflows during this period likely is better explained by a change in the frequency of larger magnitude rain events (greater than 2 or 3 inches) with time.

\section{References Cited}

Cable News Network, 2017, Aerial images show devastating flooding in central US: Cable News Network web page accessed July 5, 2017, at http:/www.cnn.com/2017/05/04/ weather/missouri-flooding-images/.

Cohn, T.A., England, J.F., Berenbrock, C.E., Mason, R.R., Stedinger, J.R., and Lamontagne, J.R., 2013, A generalized Grubbs-Beck test statistic for detecting multiple potentially influential low outliers in flood series: Water Resources Research, v. 49, no. 8, p. 5047-5058.
Cohn, T.A., Lane, W.L., and Baier, W.G., 1997, An algorithm for computing moments-based flood quantile estimates when historical flood information is available: Water Resources Research, v. 33, no. 9, p. 2089-2096.

England, J.F. Jr., Cohn, T.A., Faber, B.A., Stedinger, J.R., Thomas, W.O., Veilleux, A.G., Kiang, J.E., and Mason, R.R., 2017, Guidelines for determining flood flow frequency, Bulletin 17C: U.S. Geological Survey Techniques and Methods book 4, chap. 5, 228 p.

Federal Emergency Management Agency [FEMA], 2017a, President Donald J. Trump approves Arkansas disaster declaration, accessed July 7, 2017, at https:/www.fema.gov/news-release/2017/06/15/presidentdonald-j-trump-approves-arkansas-disaster-declaration.

Federal Emergency Management Agency [FEMA], 2017b, President Trump approves major disaster declaration for State of Oklahoma: accessed July 7, 2017, at https:/www.fema.gov/news-release/2017/05/26/presidenttrump-approves-major-disaster-declaration-state-oklahoma.

Flynn, K.M., Kirby, W.H., and Hummel, P.R., 2006, User's manual for program PeakFQ, Annual flood frequency analysis using Bulletin 17B guidelines: U.S. Geological Survey Techniques and Methods, book 4, chap. B4, 42 p.

Frankson, R., Kunkel, K., Champion, S., and Stewart, B., 2017a, Missouri State Summary: NOAA Technical Report NESDIS 149-MO, 4 p. accessed October 24, 2017, at https://statesummaries.ncics.org/mo.

Frankson, R., Kunkel, K., Champion, S., Stewart, B., Easterling, D., Hall, B., and Angel, J.R., 2017b, Illinois State Summary: NOAA Technical Report NESDIS 149-IL, 4 p., accessed October 24, 2017, at https://statesummaries.ncics.org/il.

Frankson, R., Kunkel, K., Champion, S., Stewart, B., and Runkle, J., 2017c, Indiana State Summary: NOAA Technical Report NESDIS 149-IN, 4 p. accessed October 24, 2017, at https://statesummaries.ncics.org/in.

Frankson, R., Kunkel, K., Stevens, L., Champion, S., and Stewart, B., 2017d, Oklahoma State Summary: NOAA Technical Report NESDIS 149-OK, 4 p. accessed October 24, 2017, at https://statesummaries.ncics.org/ok.

Holmes, R.R., Jr., Koenig, T.A., and Karstensen, K.A., 2010, Flooding in the United States Midwest, 2008: U.S. Geological Survey Professional Paper 1775, 64 p.

Holmes, R.R., Jr., Koenig, T.A., Rydlund, P.H., and Heimann, D.C., 2016, Examination of flood characteristics at selected streamgages in the Meramec River Basin, Eastern Missouri, December 2015-January 2016: U.S. Geological Survey Open-File Report 2016-1140, 7 p., https://doi.org/10.3133/ ofr20161140. 
Interagency Advisory Committee on Water Data, 1982, Guidelines for determining flood flow frequency (revised): U.S. Geological Survey, Office of Water Data Coordination, Bulletin 17B, 28 p., 14 app., and 1 pl.

Jennings, M.E., Thomas, T.O., Jr., and Riggs, H.C., 1994, Nationwide summary of U.S. Geological Survey regional regression equations estimating magnitude and frequency of floods for ungaged sites: U.S. Geological Survey WaterResources Investigations Report 94-4002, 196 p.

Langbein, W.B., and Iseri, K.T., 1960, General introduction and hydrologic definitions: U.S. Geological Survey WaterSupply Paper 1541-A, 29 p.

Lewis, J.M., 2010, Methods for estimating the magnitude and frequency of peak streamflows for unregulated streams in Oklahoma: U.S. Geological Survey Scientific Investigations Report 2010-5137, 41 p.

Missouri Department of Public Safety, State Emergency Management Agency, 2017, More Missouri residents and local governments will receive federal disaster assistance after FEMA approves Gov. Greiten's request to expand Missouri disaster declaration: Missouri Department of Public Safety web page, accessed July 23, 2017, at https://sema.dps.mo.gov/news/newsitem/uuid/5e3948b04416-4763-bb4b-0f4445565a20.

National Centers for Environmental Prediction, 2017, Surface Weather Maps, April 27-30, 2017: National Centers for Environmental Prediction web page, accessed June 17, 2017, at http://www.ncep.noaa.gov/.

National Oceanic and Atmospheric Administration (NOAA), National Centers for Environmental Information, 2017a, Data access: National Centers for Environmental Information web page, accessed August 2, 2017, at https://www.ncdc.noaa.gov/data-access.

National Oceanic and Atmospheric Administration (NOAA), National Centers for Environmental Information, 2017b, National Climate Report: National Centers for Environmental Information web page, accessed August 2, 2017, at https://www.ncdc.noaa.gov/sotc/national/.

National Oceanic and Atmospheric Administration (NOAA), National Centers for Environmental Information, 2017c, U.S. Climate Divisions: National Centers for Environmental Information web page, accessed June 27, 2017, at https://www.ncdc.noaa.gov/monitoring-references/maps/ us-climate-divisions.php.

National Weather Service, 2017a, National Weather Service glossary: National Weather Service web page, accessed October 23, 2017, at http://w1.weather.gov/glossary/.

National Weather Service, 2017b, 28-30 April Historic Flooding Event, Springfield, Missouri, Forecast Office: National Weather Service web page, accessed June 17, 2017, at https://www.weather.gov/ sgf/28-30AprilHistoricFloodingEvent.
Office of Missouri Governor, 2017, At Governor Greiten's request, President Trump declares major disaster in Missouri: Office of Missouri Governor web page, accessed July 7, 2017, at https://governor.mo.gov/news/archive/ governor-greitens $\% \mathrm{E} 2 \% 80 \% 99$-request-president-trumpdeclares-major-disaster-missouri.

Parrett, Charles, Melcher, N.B., and James, R.W., Jr., 1993, Flood streamflows in the upper Mississippi River basin, 1993: U.S. Geological Survey Circular 1120-A, 14 p.

Runkle, J., Kunkel, K., Champion, S., Stewart, B., and Easterling, D., 2017, Arkansas State Summary: NOAA Technical Report NESDIS 149-AR, 4 p. accessed October 24, 2017, at https://statesummaries.ncics.org/ar.

Salmi, T., Määttä, A., Anttila, P., Ruoho-Airola, T., and Amnell, T., 2002, Detecting trends of annual values of atmospheric pollutants by the Mann-Kendall test and Sen's slope estimates-The excel template application MAKESENS: Helsinki, Finland, Finnish Meteorological Institute Report 31, 35 p. accessed September 12, 2017, at http://en.ilmatieteenlaitos.fi/makesens.

Sauer, V.B., and Fulford, J.M., 1983, Floods of December 1982 and January 1983 in central and southern Mississippi River Basin: U.S. Geological Survey Open-File Report 83-213, $41 \mathrm{p}$.

Sen, P.K., 1968, Estimates of the regression coefficient based on Kendall's tau: Journal of American Statistical Association, v. 63, p. 1379-1389.

Soong, D.T., Ishii, A.L., Sharpe, J.B., and Avery, C.F., 2004, Estimating flood-peak streamflow magnitudes and frequencies for rural streams in Illinois: U.S. Geological Survey Scientific Investigations Report 2004-5103, 147 p.

Southard, R.E., 2010, Estimating the magnitude and frequency of floods in urban basins in Missouri: U.S. Geological Survey Scientific Investigations Report 2010-5073, 27 p.

Southard, R.E., and Veilleux, A.G., 2014, Methods for estimating annual exceedance-probability discharges and largest recorded floods for unregulated streams in rural Missouri: U.S. Geological Survey Scientific Investigations Report 2014-5165, 39 p., https://doi.org/10.3133/sir20145165.

U.S. Geological Survey, 2017a, National Water Information System-Web interface: accessed June 30, 2017, at https://doi.org/10.5066/F7P55KJN.

U.S. Geological Survey, 2017b, WaterWatch, Flood—Flood Table Builder: U.S. Geological Survey, accessed on July 5, 2017, at https://waterwatch.usgs.gov/.

Veilleux, A.G., Cohn, T.A., Flynn, K.M., Mason, R.R., and Hummel, P.R., 2013, Estimating magnitude and frequency of floods using the PeakFQ 7.0 program: U.S. Geological Survey Fact Sheet 2013-3108, 2 p. 
Wagner, D.M., Krieger, J.D., and Veilleux, A.G., 2016,

Methods for estimating annual exceedance probability

discharges for streams in Arkansas, based on data through

water year 2013: U.S. Geological Survey Scientific Investi-

gations Report 2016-5081, 136 p., https://doi.org/10.3133/

sir20165081.

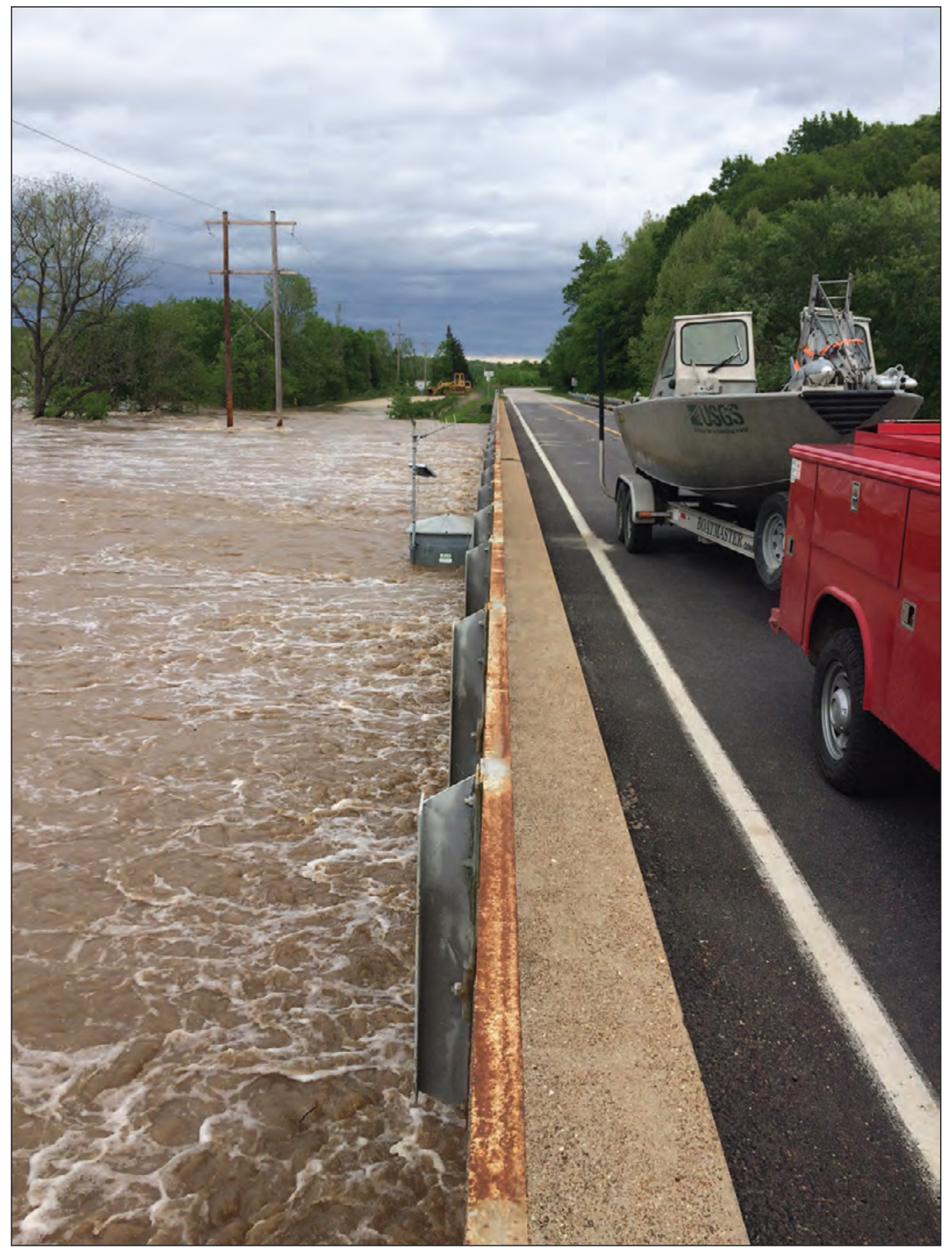

Gasconade River near Rich Fountain, Mo., May 1, 2017. Photograph by Larry Buschmann, USGS. 


\section{Glossary}

Note: Glossary definitions are from Langbein and Iseri (1960), Holmes and others (2010), and National Weather Service (2017a).

annual exceedance probability (AEP) The probability, or chance, of a flood of a given streamflow magnitude being equaled or exceeded in any given year. The probability can be expressed as a fraction, decimal, or percentage.

annual exceedance probability flood quantile (AEP flood quantile) The value of the peak streamflow that corresponds to a particular annual exceedance probability (for example, 1-percent AEP flood quantile)

Bulletin 17B Report by the Interagency Advisory Committee on Water Data (1982) that delineates the recommended method for flood-probability analysis in the United States.

Bulletin17C Report published by the U.S. Geological Survey in 2017 representing the efforts of the Advisory Committee on Water Information, that updates the methods for flood-probability analysis in the United States presented in Bulletin 17B.

confidence limits To gauge the accuracy of an approximation based on a probability distribution, upper and lower confidence limits can be estimated based on the properties of the probability distribution. This report includes the 95-percent confidence limits of the estimate of the flood quantiles as computed by the methods outlined in Bulletin 17B.

discharge In its simplest concept discharge means outflow; therefore, the use of this term is not restricted as to course or location, and it can be applied to describe the flow of water from a pipe or from a drainage basin.

expected moment algorithm The expected moment algorithm (EMA) is an updated method for fitting the log pearson type III probability distribution that is a more effective means of incorporating historical peak streamflow information into a flood-frequency analysis than the previous Bulletin 17B method. The EMA can accommodate interval data, which simplifies analysis of datasets containing historic data, potentially influential low flows (PILFs), and uncertain data points while also providing enhanced confidence intervals on the estimated peak streamflows.

flood An overflow or inundation that comes from a river or other body of water, and causes or threatens damage.

flood peak The highest value of the stage or streamflow attained by a flood; often designated as peak stage or peak streamflow respectively.

flood quantile See "annual exceedance probability flood quantile."

flood stage The stage at which overflow of the natural banks of a stream begins to cause damage in the reach in which the water surface elevation is measured.

hydrograph A graph showing stage, streamflow, velocity, or other property of water with respect to time.

\section{log-Pearson Type III probability distribu-} tion One of the family of probability distributions developed by Karl Pearson that is used in the United States as a best-fit for the distribution of annual peak flood streamflows in the Bulletin 17B analysis procedures developed by the Interagency Advisory Committee on Water Data (1982).

peak-of-record streamflow The largest instantaneous streamflow value for the period that data have been collected.

peak stage See "flood peak." peak streamflow See "flood peak." precipitation As used in hydrology, precipitation is the discharge of water, in liquid or solid state, out of the atmosphere, generally upon a land or water surface. It is the common process by which atmospheric water becomes surface or subsurface water. The term "precipitation" also is commonly used to designate the quantity of water that is precipitated.

probability A means to express the likelihood of something occurring, also known as chance. The probability can be expressed as a fraction, decimal, or percentage. 
probability distribution Describes the range of possible values that a random variable can attain and the probability that the value of the random variable is within any subset of that range.

recurrence interval The average interval of time within which the given flood is expected to be equaled or exceeded once.

regional regression equation (RRE) Equation developed through use of regression techniques that relate the flood-probability data at many streamgages in a region to the basin characteristics of the streams monitored by the streamgages. For any location along a stream, a user can enter the basin characteristics (drainage area, basin slope, and so forth) as independent variables into the equations and compute various flow characteristics (for example, 1-percent AEP flood quantile, 2-percent AEP flood quantile, and annual mean streamflow).
Sen's slope estimate A nonparametric estimate of trend based on the median slope of data pairs in a time series.

stage Height of a water surface above an established datum, also known as gage height.

stationary front A front between warm and cold air masses that is moving very slowly or not at all.

streamflow The discharge that occurs in a natural channel. Although the term discharge can be applied to flow in a canal, the word streamflow uniquely describes the discharge in a surface stream course. The units of measurement often are reported in cubic feet per second $\left(\mathrm{ft}^{3} / \mathrm{s}\right)$.

streamgage A particular site on a stream where a record of streamflow is obtained.

trend The change of a particular variable with either time or spatial location as computed by statistical analysis.

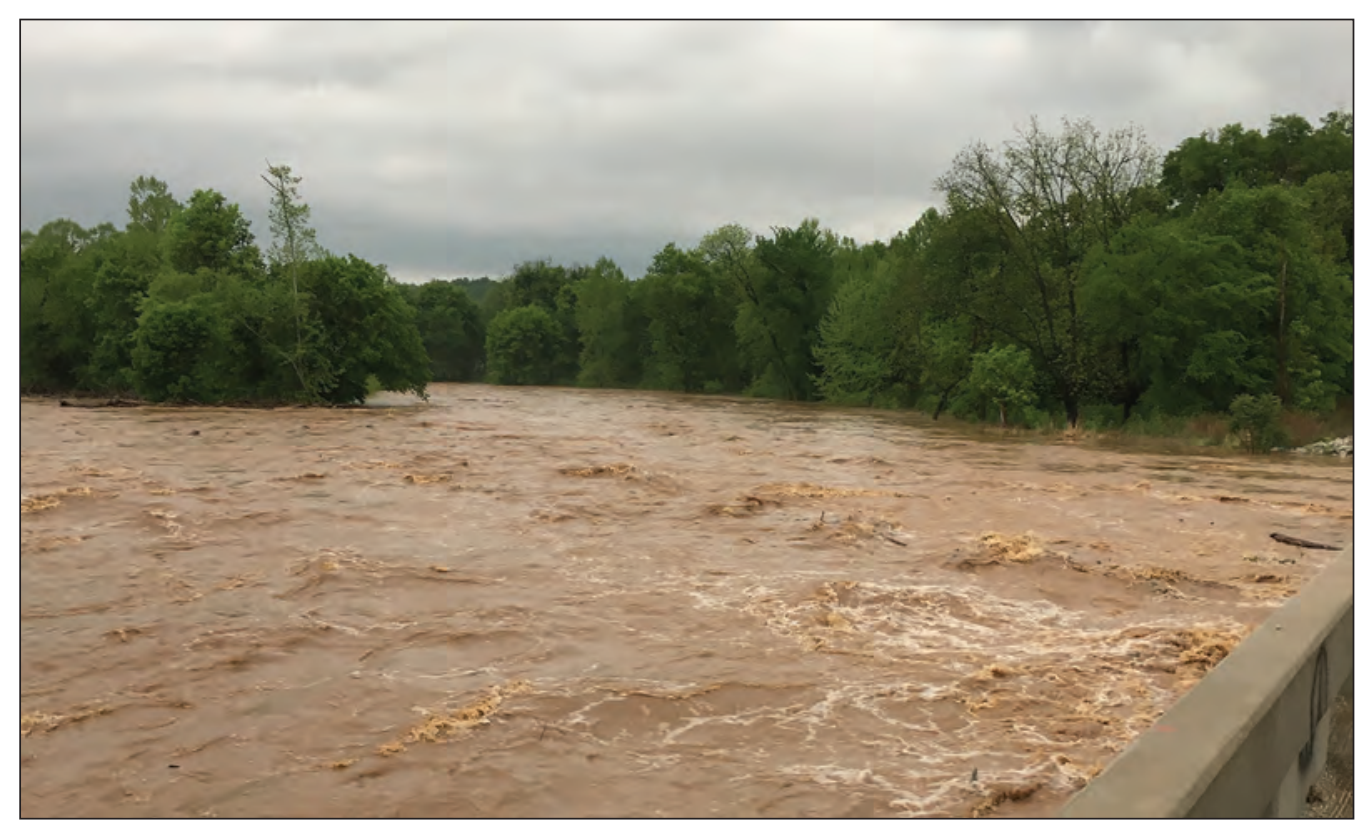

Spavinaw Creek near Sycamore, Okla., April 29, 2017. Photograph by U.S. Geological Survey.

For more information about this publication, contact

Director, USGS Missouri Water Science Center

1400 Independence Road

Rolla, M0 65401

(573) 308-3667

For additional information visit https://mo.water.usgs.gov

Publishing support provided by the

Rolla Publishing Service Center 
Back cover. USGS hydrologic technician wading St. Francis River near Patterson, Mo., April 30, 2017. Photograph by Josh Keele, USGS. 


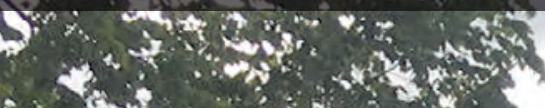

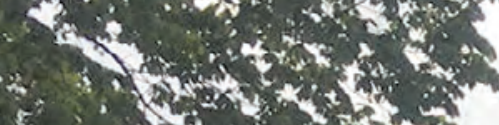
$5 \quad+4=2$

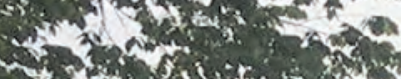

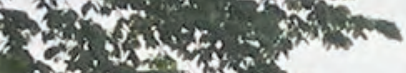

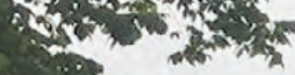

4. " a

$a^{2}+2 x$ a

(a)

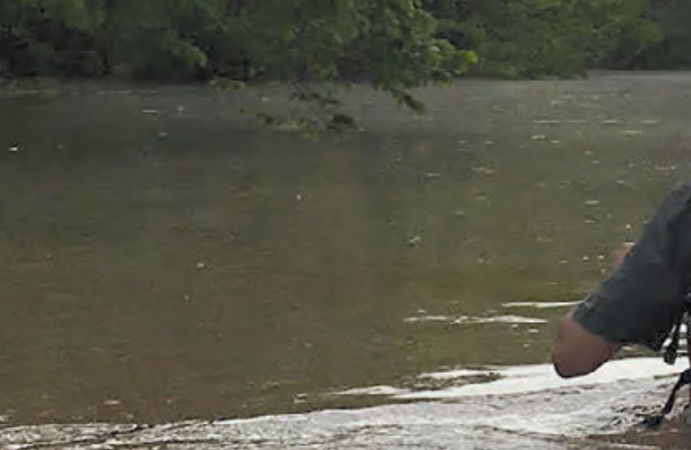

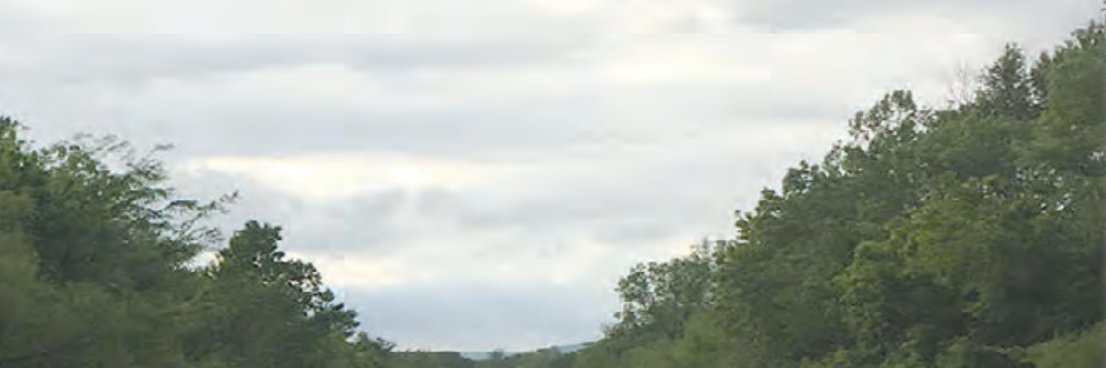

$\rightarrow$
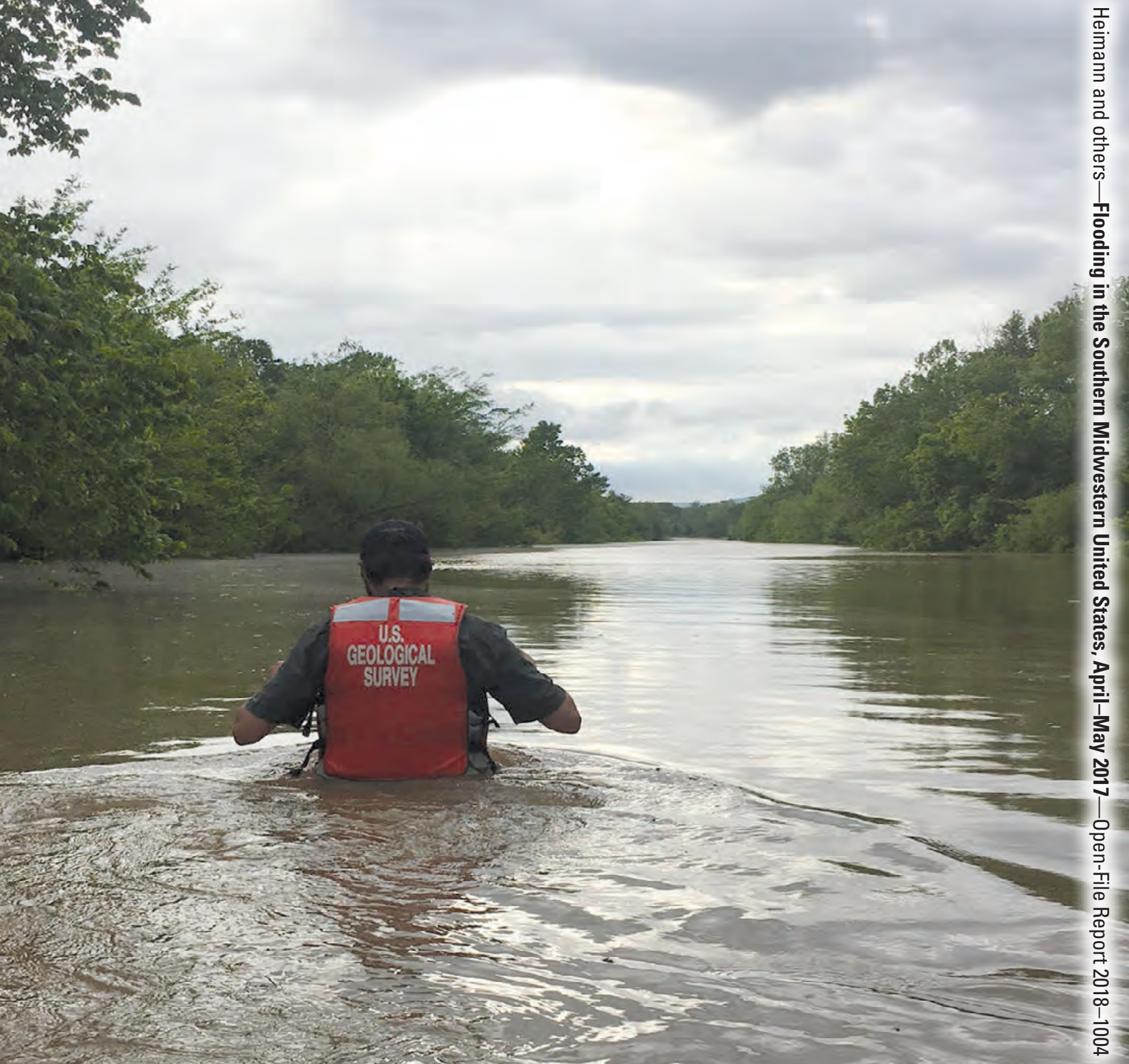

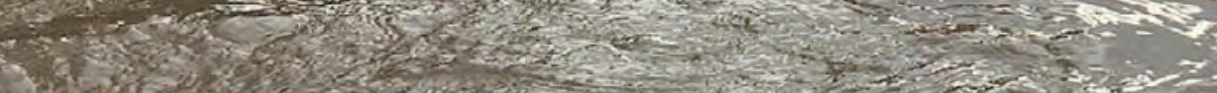

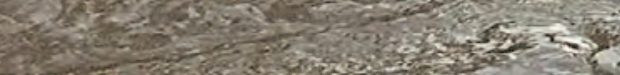

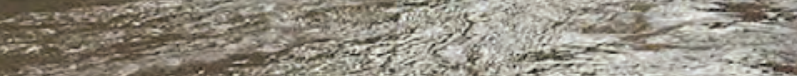

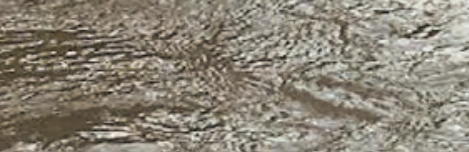
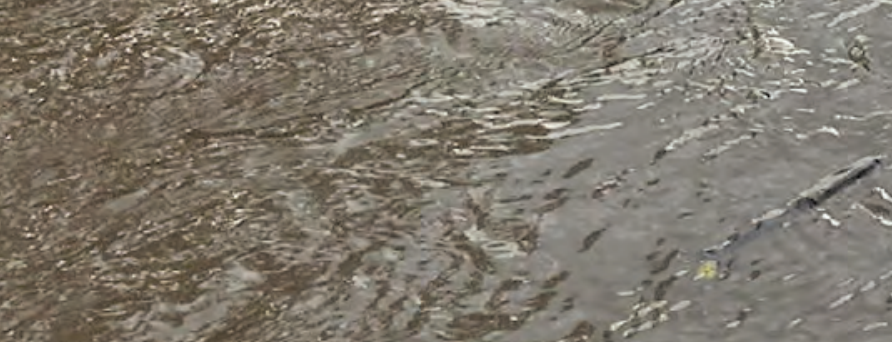